Supporting Information

$$
\text { for }
$$

\title{
Co-Localization Strategy Unveils an Underside Binding Site in the Transmembrane Domain of Smoothened Receptor
}

Fang Zhou, Kang Ding, Yiqing Zhou, Yang Liu, Xiaoyan Liu, Fei Zhao, Yiran Wu, Xianjun

Zhang, Qiwen Tan, Fei Xu, Raymond C. Stevens, Wenfu Tan, Youli Xiao, Suwen Zhao and Houchao Tao 


\section{Supporting Information}

\section{Table of Contents}

\section{SUPPLEMENTARY TABLES AND FIGURES}

Figure S1. Ligands co-crystallized with smoothened receptor

Figure S2. Ligands not co-crystallized with smoothened receptor

Table S1. Interaction of Allo-1 with CP, SAGs

Figure S3. Structure of BODIPY-CP, a classic fluorescent probe for smoothened receptor

Figure S4. Allo-1 does not bind where BODIPY binds

Figure S5. Specific binding to SMO of probe 3

Figure S6. Diazirine equipped photoaffinity probe 4 exhibited significant loss of activity

Table S2. Distances between residues labeled by probe $\mathbf{1}$ and probe $\mathbf{2}$

Figure S7. Distance between two nitrogens of probe $\mathbf{1}$ and probe $\mathbf{2}$

Figure S8. Allo-1 is about $3.7 \AA$ away from Asp473

Table S3. Binding free energy and docking scores for the Allo-1 analogs

Figure S9. Docking results of Allo-1 analogs for the study of ligand-protein interaction

Figure S10. LY2940680 is partially overlapped with Allo-1

Figure S11. The competitive binding of Allo-2 with LY2940680 derived probe BODIPY-LY

Figure S12. The binding competition between Allo-2 and Probe 3.

II. EXPERIMENTAL SECTION

Procedures for molecular docking

Procedures for molecular dynamic simulation

Procedures for cell-based luciferase reporter assay

Procedures for fluorescence based competition assay

Procedures for photoaffinity labeling

Procedures for photoaffinity labeling and fluorescent gel-based analysis

Synthesis of Allo-1 derived probes

Synthesis of Allo-1 analogs for silence research

Synthesis of LY probe for competition test

III. NMR SPECTRA

IV. PURITY CHARACTERIZATION

V. REFERENCES 

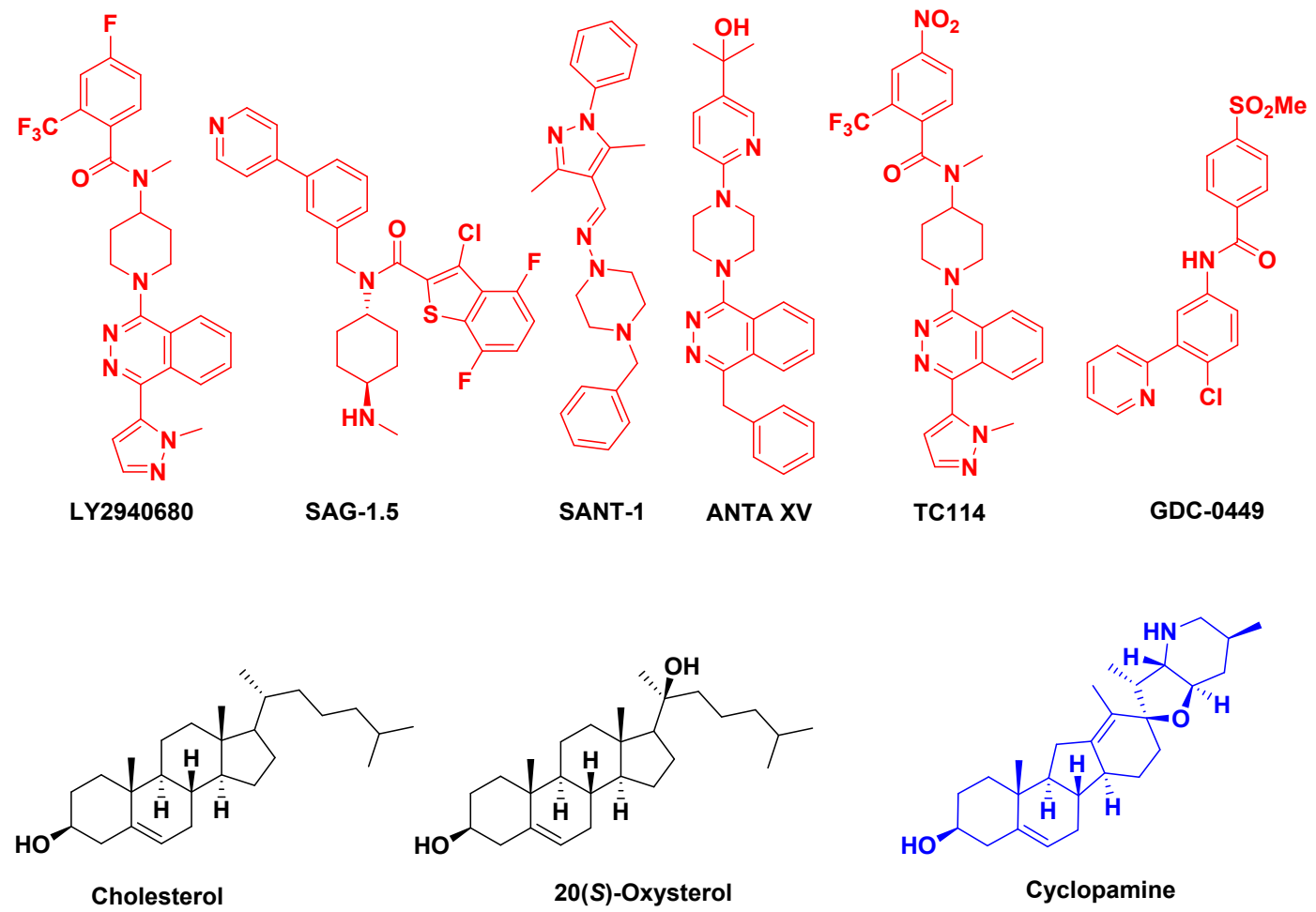

Figure S1. Ligands co-crystallized with smoothened receptor. Compounds, including LY2940680, SAG-1.5, SANT-1, ANTA XV, TC114 and GDC-0449, bound in transmembrane domain are colored in red, while compounds, including cholesterol and its metabolite 20(S)oxysterol, in extracellular domain in black. Cyclopamine (CP) in blue can be bound in both domains. 

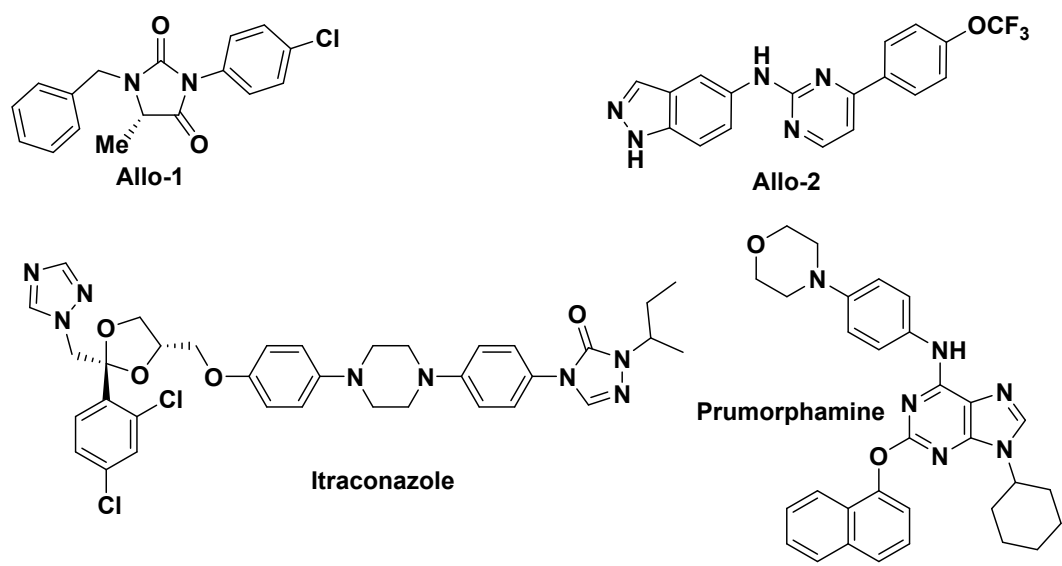

Figure S2. Ligands not co-crystallized with smoothened receptor also maintain inhibitory activity against drug-resistant mutant SMO. 
Table S1. Known interactions of Allo-1 with CP, SAG and their derivatives ${ }^{1}$.

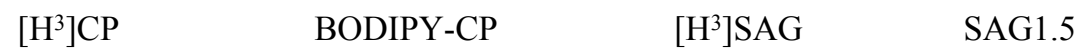

\begin{tabular}{|c|c|c|c|c|}
\hline Allo-1 & Non-competition & Competition & Non-competition & $\begin{array}{l}\text { Non-competitive } \\
\text { inhibition }\end{array}$ \\
\hline Allo-2 & Competition & Competition & Non-competition & $\begin{array}{l}\text { Non-competitive } \\
\text { inhibition }\end{array}$ \\
\hline
\end{tabular}




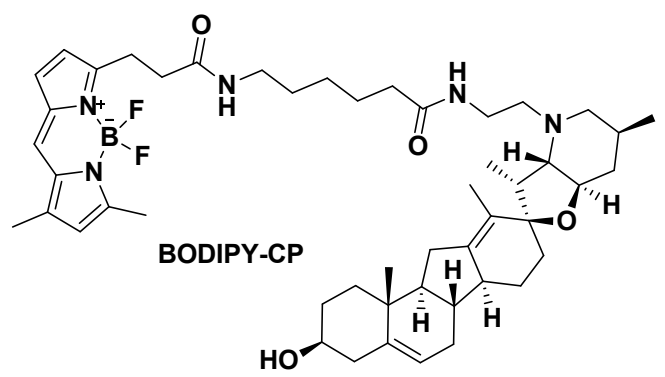

Figure S3. Structure of BODIPY-CP, a classic fluorescent probe for smoothened receptor ${ }^{2}$. 
A

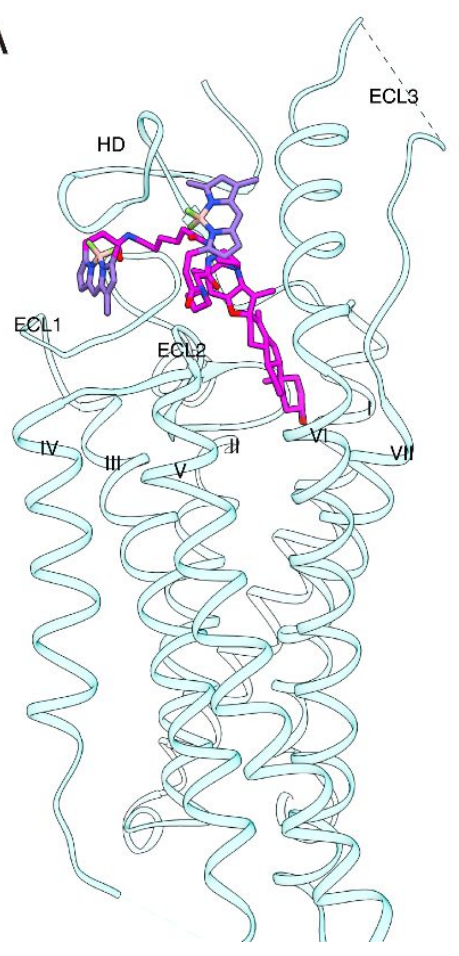

B

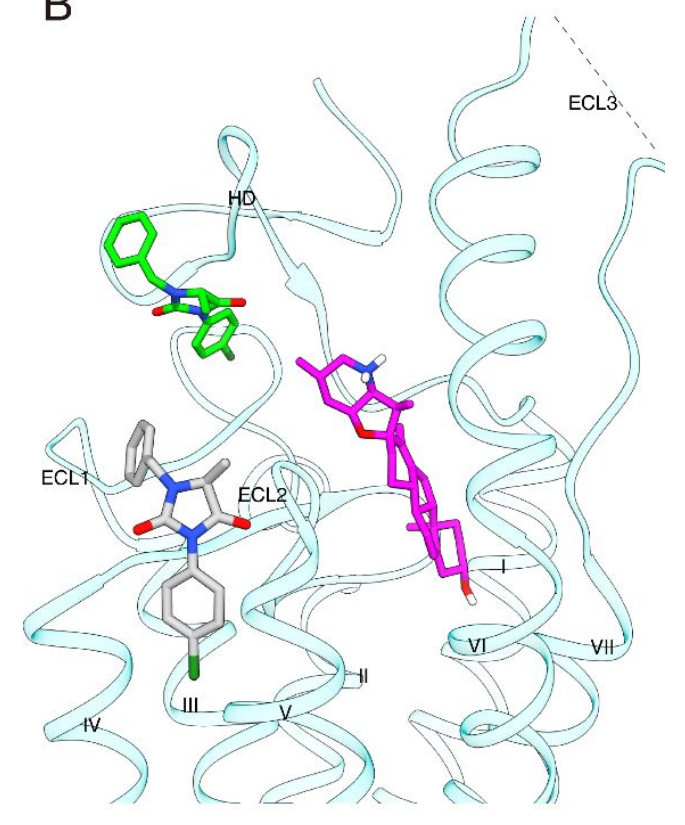

Figure S4. Allo-1 does not bind where BODIPY binds (PDB codes: 4O9R). (A) Docking of BODIPY-CP in the co-crystal structure of SMO with CP. BODIPY in probe BODIPY-CP was found floating in the outward vicinity of CP binding in SMO with a moderate score. Two possible binding poses of BODIPY were generated, as shown in violet. (B) When BODIPY was replaced with Allo-1, the docking pose (green) showed non-stable binding in a short molecular dynamics simulation (grey). 


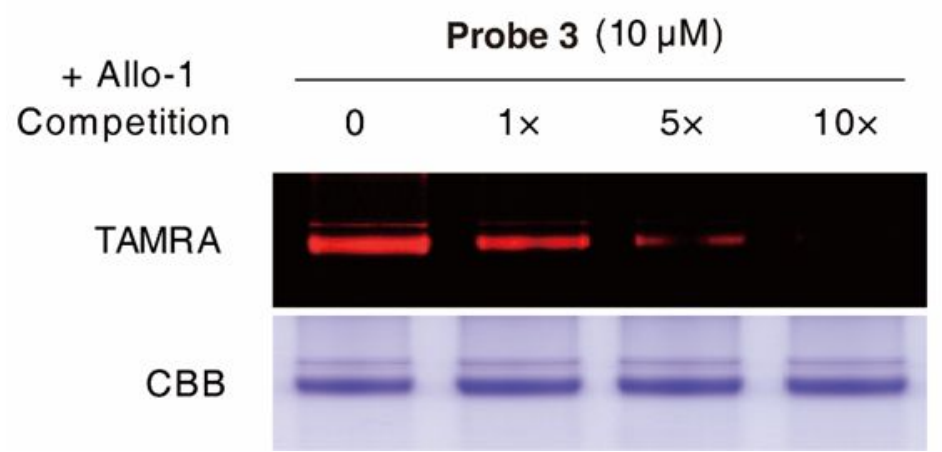

Figure S5. Specific binding to SMO of probe 3 was proved by competition test in the presence of various concentrations of Allo-1. 


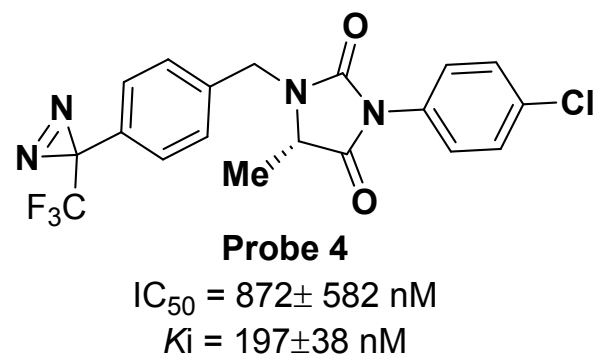

Figure S6. Diazirine equipped photoaffinity probe 4 exhibited losses of activity and binding affinity. 
Table S2. Distances between residues labeled by Probe $\mathbf{1}$ and Probe $\mathbf{2}$.

\begin{tabular}{cccccc}
\hline Probe 1 & E135 & K186 & L498 & K510 & E518 \\
\hline H103 & $20.7 \AA$ & $19.8 \AA$ & $15.6 \AA$ & $36.0 \AA$ & $49.3 \AA$ \\
E158 & $23.6 \AA$ & $27.5 \AA$ & $18.0 \AA$ & $22.5 \AA$ & $37.1 \AA$ \\
T349 & $101.9 \AA$ & $85.4 \AA$ & $78.5 \AA$ & $58.0 \AA$ & $41.9 \AA$ \\
G527 & $106.1 \AA$ & $90.5 \AA$ & $81.8 \AA$ & $61.0 \AA$ & $46.1 \AA$ \\
T528 & $80.1 \AA$ & $63.2 \AA$ & $53.9 \AA$ & $33.4 \AA$ & $14.4 \AA$ \\
G529 & $79.1 \AA$ & $63.3 \AA$ & $53.8 \AA$ & $34.4 \AA$ & $14.8 \AA$ \\
\hline
\end{tabular}




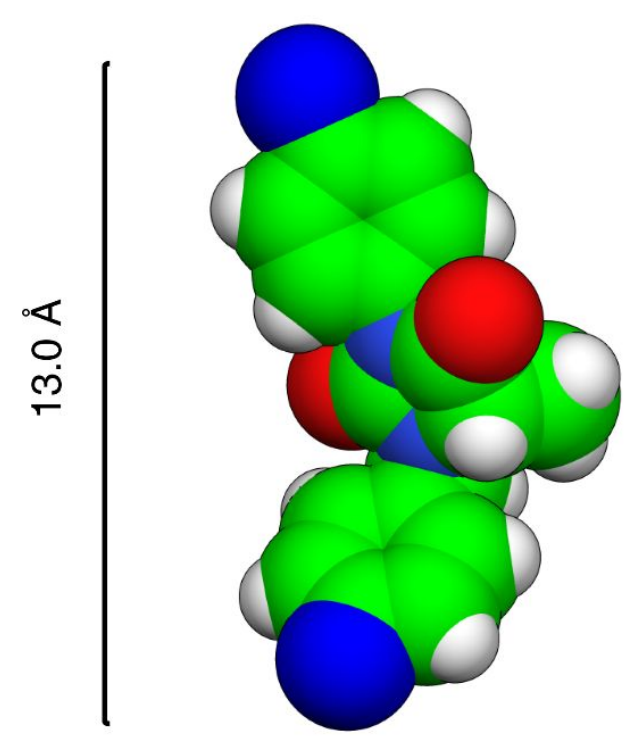

Figure S7. Distance between two nitrogens of probe $\mathbf{1}$ and probe $\mathbf{2}$ is $13.0 \AA$. 


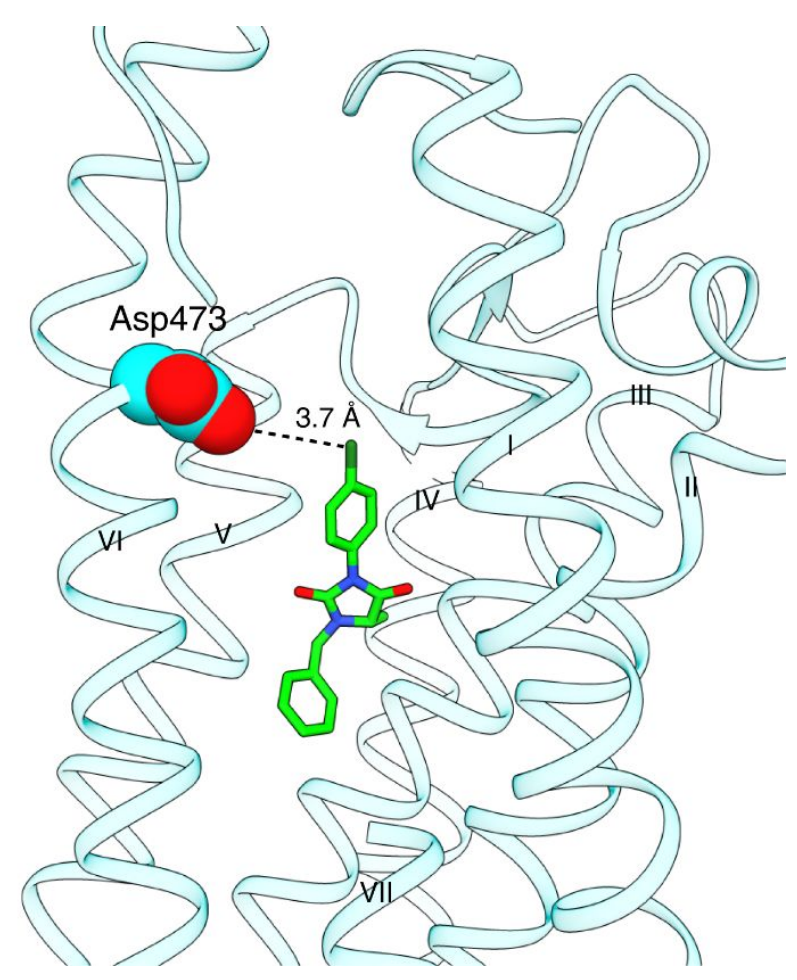

Figure S8. Allo-1 is about $3.7 \AA$ away from Asp473 (PDB code: 4N4W). 
Table S3. Computational calculation of binding free energy and docking scores for the Allo-1 analogs.

\begin{tabular}{|c|c|c|c|}
\hline Compds. & XP gScore & $\begin{array}{c}\text { MM-GBSA dG bind } \\
(\mathrm{kcal} / \mathrm{mol})\end{array}$ & $\mathrm{IC}_{50}(\mathrm{nM})$ \\
\hline Allo-1 & -11.405 & -88.45 & $59 \pm 9$ \\
\hline 5 & -10.945 & -76.77 & $383 \pm 109$ \\
\hline 6 & -11.371 & -79.88 & $7382 \pm 2618$ \\
\hline 7 & -10.635 & -80.30 & $547 \pm 453$ \\
\hline 8 & -11.737 & -85.26 & $92 \pm 38$ \\
\hline 9 & -10.557 & -69.95 & $8006 \pm 1994$ \\
\hline 10 & -11.213 & -73.49 & $1533 \pm 262$ \\
\hline 11 & -10.581 & -82.12 & $8097 \pm 1921$ \\
\hline 12 & -11.014 & -75.18 & $3791 \pm 673$ \\
\hline 13 & -11.246 & -85.19 & $4552 \pm 2245$ \\
\hline
\end{tabular}

Corresponding Structures:<smiles>C[C@H]1C(=O)N(c2ccc(Cl)cc2)C(=O)N1Cc1ccccc1</smiles>
Allo-1<smiles>C[C@H]1C(=O)N(c2ccc(Cl)cc2)C(=O)N1CC1CCCCC1</smiles><smiles>Cc1c(F)c(F)c(F)c(F)c1CN1C(=O)N(c2ccc(Cl)cc2)C(=O)[C@H]1C</smiles>

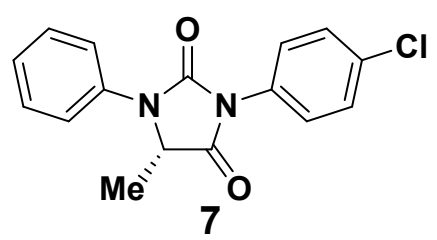<smiles>C[C@H]1C(=O)N(c2ccc(Cl)cc2)C(=O)N1CCc1ccccc1</smiles>

8<smiles>C[C@H]1C(=O)N(C2CCCCC2)C(=O)N1Cc1ccccc1</smiles>

9<smiles>C[C@H]1C(=O)N(c2c(F)c(F)c(F)c(F)c2F)C(=O)N1Cc1ccccc1</smiles><smiles>C[C@@H]1C(=O)N(Cc2ccc(Cl)cc2)C(=O)N1Cc1ccccc1</smiles><smiles>C[C@H]1C(=O)N(c2ccc(Cl)cc2)C(=S)N1Cc1ccccc1</smiles>

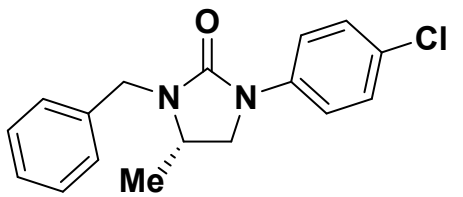

13 


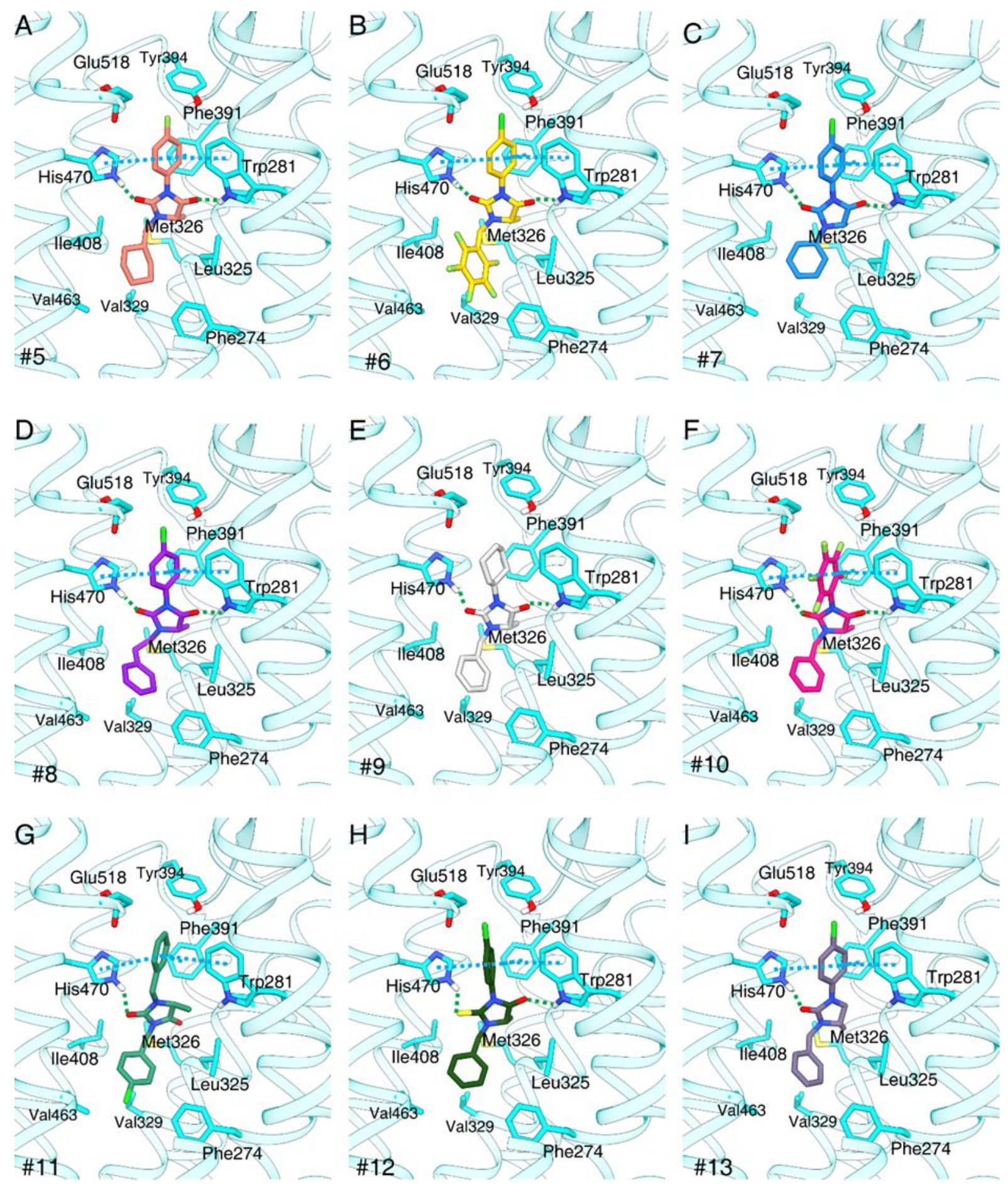

Figure S9. Docking study of Allo-1 analogs (PDB code: 4N4W). 


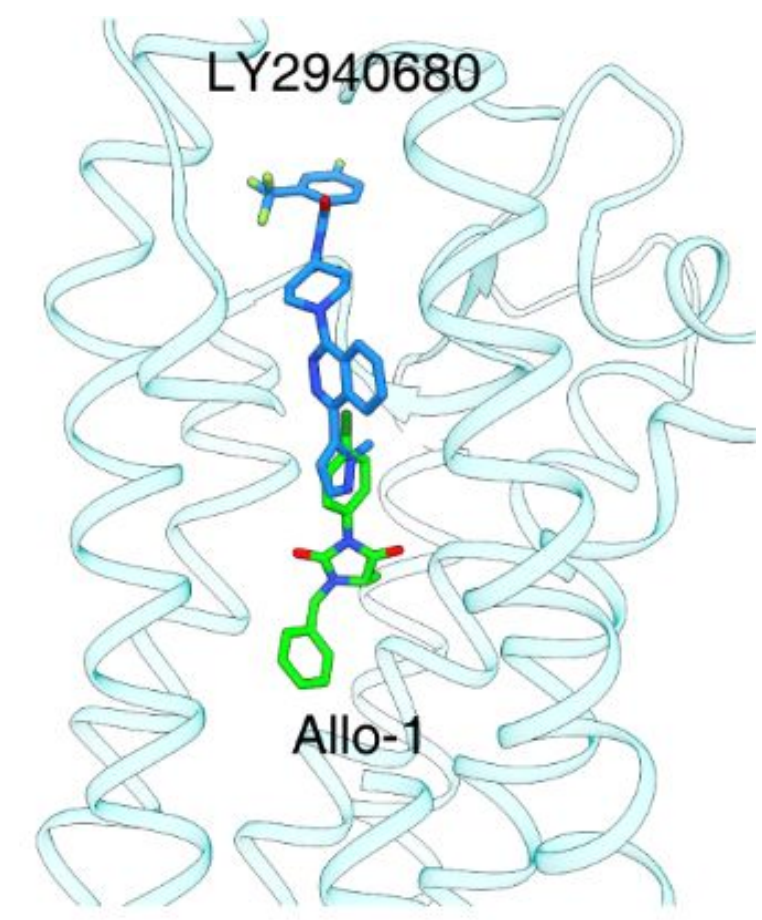

Figure S10. LY2940680 is partially overlapped with Allo-1 (PDB code: 4N4W). 
Flourescence based competitive binding test

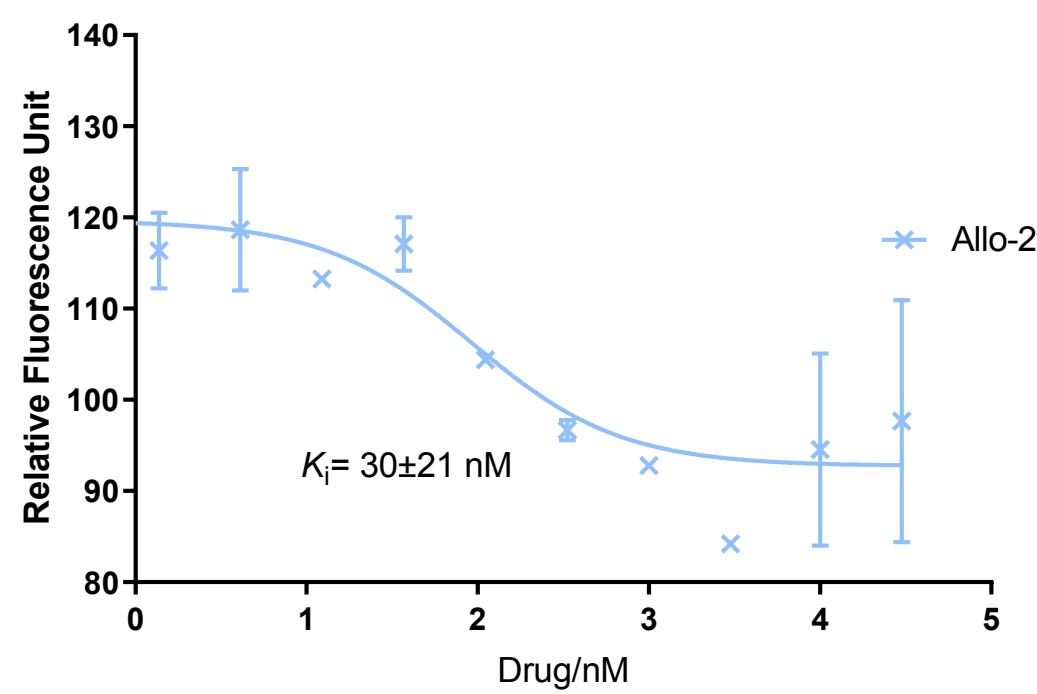

Figure S11. The competitive binding of Allo-2 with LY2940680 derived probe BODIPY-LY. 


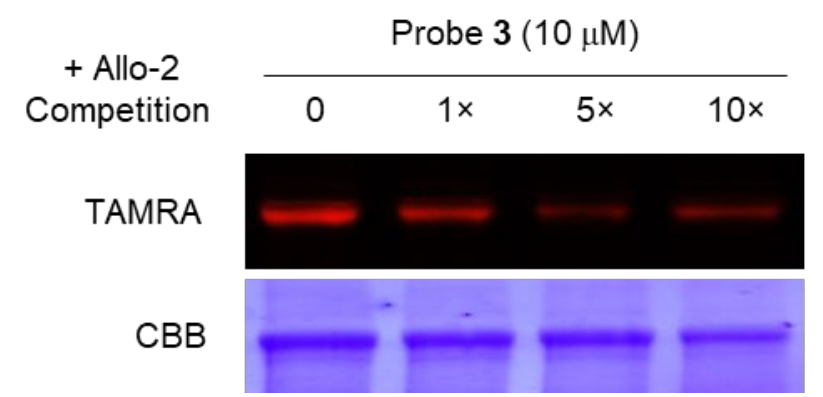

Figure S12. Probe 3 used for Allo-1 specific labeling was competed by the addition of Allo2. 


\section{Procedures for molecular docking}

Structures of SMO receptor (PDB code: $4 \mathrm{O}^{3} \mathrm{R}^{3}, 4 \mathrm{~N}^{4} \mathrm{~W}^{3}$ ) were obtained from RCSB PDB server, and fusion partners and non-ligand molecules were removed. Protein structures were processed by Prepwizard ${ }^{4}$ of Schrödinger 2015-4 suite ${ }^{5}$ with default parameters. Glu518 was neutralized by Propka of Schrödinger 2015-4 suite. Structures of Allo-1, BODIPY-CP and other small molecules were prepared by LigPrep of Schrödinger 2015-4 suite with default parameters. BODIPY-CP was docked into SMO (4O9R) by Glide $\mathrm{XP}^{6}$, with a core of heavy atoms of CP with RMSD less than $0.3 \AA$. Allo-1 was docked into SMO (4O9R) by Glide XP. Docking of allosteric site: Induced-Fit Docking ${ }^{7}$ workflow was used for initial docking of Allo1 into SMO (4N4W) with default parameters and Leu325 was restrained. Other Allo-1 analogs and Allo-2 were docked into the Induced-Fit docking trained conformation of SMO by Glide $\mathrm{XP}$, followed by Prime/MM-GBSA ${ }^{8}$ for free-energy scoring. 


\section{Procedures for molecular dynamic simulation}

Molecular dynamic simulation of two complexes, Allo-1/CP-SMO (4O9R), Allo-1-SMO (4N4W) were processed by GROMACS 5.1.2 ${ }^{9}$ in a local HPC cluster. Protein of these three complexes were parametrized by Amber99-SB-ILDN ${ }^{10}$ force field, and the N-terminal and Cterminal were capped by ACE and CT3 respectively, and Glu518 was neutralized. Ligands were parameterized by antechamber of AMBER14 ${ }^{11}$ with GAFF $^{12}$ and AM1-BCC charge model, and then converted to GROMACS format by ACPYPE ${ }^{13}$. Protein-membrane system was built by CHARMM-GUI ${ }^{14}$ server with $\sim 128$ POPC lipids in a rectangular box, and all POPC lipids were converted to Stockholm lipids force field ${ }^{15}$ format, which is an AMBER consistent force field for lipids. Model of water and ions are TIP3P, $\mathrm{Na}^{+}$and $\mathrm{Cl}^{-}$at a concentration of $0.15 \mathrm{M}$. The equilibration of molecular system included a 5000-step minimization, a short NVT equilibration, and 5 NPT equilibration with a decreasing restraint described as CHARMM-GUI. After equilibration, a 200 ns production molecular dynamics was launched. Long distance cut-off was $10 \AA$ and the covalent bond of $\mathrm{H}$ was constrained by LINCS $^{16}$ algorithm. The energy and RMSD analysis were analyzed by GROMACS 5.1.2, the interaction finger prints were calculated by ODDT ${ }^{17}$ library of Python for every $10 \mathrm{~ns}$ per frame from simulation trajectory. 


\section{Procedures for cell-based luciferase reporter assay}

The activities of newly synthesized Allo-1 analogs were measured with cell-based luciferase reporter assay. NIH3T3 cells expressed firefly luciferase gene with the regulation of Gli responsive. The cells were then cultured to confluency with DMEM consisting of $175 \mu \mathrm{g} / \mathrm{mL}$ hygromycin and 10\% (v/v) newborn calf serum in 96-well plates. After that, various concentrations of Allo-1 compounds in DMEM containing 0.5\% NCS was added. After 2 hours' incubation at $37^{\circ} \mathrm{C}$, SAG (commercial source) was added to the final concentration of 100 mM. After another 24 hours' incubation at $37{ }^{\circ} \mathrm{C}$, the intensity of the firefly luciferase was tested with Bright-Glo ${ }^{\circledR}$ Luciferase Assay System (Promega) on the Envision (PerkinElmer) under the guidance of description. The inhibition curve and $\mathrm{IC}_{50}$ of these antagonists were obtained with GraphPad Prism. Each point of data was the mean of the duplicated results. 


\section{Procedure for fluorescence-based competition assay}

The engineered SMO construct was expressed in HEK293F cells (Invitrogen) in the presence of $5 \mu \mathrm{M}$ vismodegib. HEK293F cells at a cell density of $1.0-1.3^{*} 10^{6}$ cells $\mathrm{mL}^{-1}$ were transiently transfected with PEI:DNA at a ratio of $2: 1$, and cultured at $37^{\circ} \mathrm{C}$. The cells were seeded into 96-well plates and subjected to BODIPY-LY in a $2 \mu \mathrm{M}$ final concentration. After incubation for 10 minutes at $4{ }^{\circ} \mathrm{C}$, the cells were subjected to various concentrations of tested ligand and incubated for another 15 minutes at $4{ }^{\circ} \mathrm{C}$. Unbound compounds were removed by centrifugation and wash. The cells were resuspended and analyzed by a flow cytometry. Data were plotted, and $K_{\mathrm{i}}$ values were determined using GraphPad Prism. Each data point represents the mean \pm s.d. repeated in triplicates. 


\section{Procedures for photoaffinity labeling}

Recombinant SMO protein $(10 \mu \mathrm{g}, 0.5 \mu \mathrm{g} / \mu \mathrm{L})$ was incubated with probe $\mathbf{1}$ or probe $\mathbf{2}$ (both 20 $\mu \mathrm{M})$ at room temperature for $3 \mathrm{~h}$, followed by UV irradiation (365 nm, 8 watt) for $15 \mathrm{~min}$ on ice. $4 \mu \mathrm{L}$ of ProteaseMax solution (Promega, $1 \%$ in $50 \mathrm{mM} \mathrm{NH}_{4} \mathrm{HCO}_{3}$ ) was added and incubated at room temperature for another $30 \mathrm{~min} .75 \mu \mathrm{L}$ of $50 \mathrm{mM} \mathrm{NH}_{4} \mathrm{HCO}_{3}$ was added and the samples were reduced with $20 \mathrm{mM}$ DTT at $56{ }^{\circ} \mathrm{C}$ for $15 \mathrm{~min}$ and alkylated with $50 \mathrm{mM}$ iodoacetamide at room temperature for $30 \mathrm{~min}$ in dark. $1 \mu \mathrm{L}$ of ProteaseMax solution (Promega) was added and the samples were subjected to in solution digestion with $1 \mu \mathrm{g}$ of trypsin/LysC mixture (Promega) at $37^{\circ} \mathrm{C}$ overnight. The digests were desalted by Ziptip desalting column (Pierce) and evaporated to dryness on a SpeedVac. The dried peptides were suspended in $8 \mu \mathrm{L}$ $\mathrm{ddH}_{2} \mathrm{O}$ containing $0.1 \%$ formic acid with sonication.

A volume of $3.0 \mu \mathrm{L}$ of each sample was desalted by loading on a Thermo C18 PepMap100 precolumn $(300 \mathrm{~mm} \times 5 \mathrm{~mm})$ and eluted on a Thermo Acclaim PepMap RSLC analytical column $(75 \mathrm{~mm} \times 15 \mathrm{~cm})$. Mobile phase $\mathrm{A}\left(0.1 \%\right.$ formic acid in $\left.\mathrm{H}_{2} \mathrm{O}\right)$ and mobile phase $\mathrm{B}(0.1 \%$ formic acid in acetonitrile) were used to establish the 120 min gradient comprised of 85 min of $4-30 \% \mathrm{~B}, 15 \mathrm{~min}$ of $30-50 \% \mathrm{~B}$, and $5 \mathrm{~min}$ of $90 \% \mathrm{~B}$, followed by re-equilibrating at $4 \% \mathrm{~B}$ for $15 \mathrm{~min}$. The flow rate was $0.3 \mathrm{~mL} / \mathrm{min}$. Peptides were then analyzed on a Thermo Orbitrap Fusion Lumos proteomic mass spectrometer (Thermo Scientific) in a data-dependent manner, with automatic switching between MS and MS/MS scans using a top 10 method. MS spectra were acquired at a resolution of 70000 with a target value of $3 \times 10^{6}$ ions or a maximum integration time of $50 \mathrm{~ms}$. The scan range was limited from 375 to $1400 \mathrm{~m} / \mathrm{z}$. Peptide fragmentation was performed via higher-energy collision dissociation (HCD) with the energy set at $32 \mathrm{NCE}$. The MS/MS spectra were acquired at a resolution of 35000 with a target value of $1 \times 10^{5}$ ions or a maximum integration time of $100 \mathrm{~ms}$. The fixed first $\mathrm{m} / z$ was 100 , and the isolation window was $1.2 \mathrm{~m} / \mathrm{z}$.

Data processing was performed using Proteome Discoverer 2.1 software (Thermo Scientific) and peptide sequences were determined by matching protein database with the acquired fragmentation pattern by SEQUEST HT algorithm. The precursor mass tolerance was set to 10 ppm and fragment ion mass tolerance to $0.02 \mathrm{Da}$. Two missed cleavage site of trypsin was 
allowed. Probe 1 or probe $\mathbf{2}$ (any amino acids), Carbamidomethyl (C), and Oxidation (M) were used as variable modifications. All spectra were searched against protein sequence of SMO protein using a target false discovery rate (FDR) of $1 \%$. Manual verification was performed to ensure confident peptide identification. 


\section{Procedures of photoaffinity labeling and fluorescent gel-based analysis}

Recombinant human SMO protein was diluted to a final concentration of $0.1 \mu \mathrm{g} / \mu \mathrm{L}$ in buffer (25 mM HEPES, $100 \mathrm{mM} \mathrm{NaCl}, \quad 0.01 \%$ n-Dodecyl- $\beta$-D-Maltoside (DDM), $0.002 \%$ Cholesteryl Hemisuccinate (CHS), 5\% glycerol) and incubated with probe $\mathbf{3}$ as indicated for 1 $\mathrm{h}$ at room temperature. Samples were transferred to 96-well plate and irradiated with UV (365 $\mathrm{nm}, 8 \mathrm{Watt}$ ) on ice for 20 minutes. Each of $20 \mu \mathrm{L}$ protein samples were transferred to $0.6 \mathrm{~mL}$ tube and added with freshly prepared $0.25 \mu \mathrm{L}$ each of TAMRA-N ${ }_{3}(10 \mathrm{mM}$ stock in DMSO, Lumiprobe), $\mathrm{CuSO}_{4}$ (100 mM stock in $\mathrm{H}_{2} \mathrm{O}$ ), THPTA (Tris(3-hydroxypropyltriazolylmethyl) amine, $10 \mathrm{mM}$ stock in $\mathrm{H}_{2} \mathrm{O}$, Sigma) and sodium ascorbate $\left(100 \mathrm{mM}\right.$ stock in $\left.\mathrm{H}_{2} \mathrm{O}\right)$. The samples were incubated at room temperature for $1 \mathrm{~h}$ and the reaction was quenched by addition of $5 \mu \mathrm{L}$ of SDS-PAGE loading buffer. $20 \mu \mathrm{L}$ of each sample was applied to SDS-PAGE and detected by FUJIFILM FLA 9000 plus DAGE fluorescence scanner. Finally, the gel was visualized by coomassie blue staining. 


\section{Chemical synthesis}

Scheme S1. Synthesis of photoaffinity probe 1-4
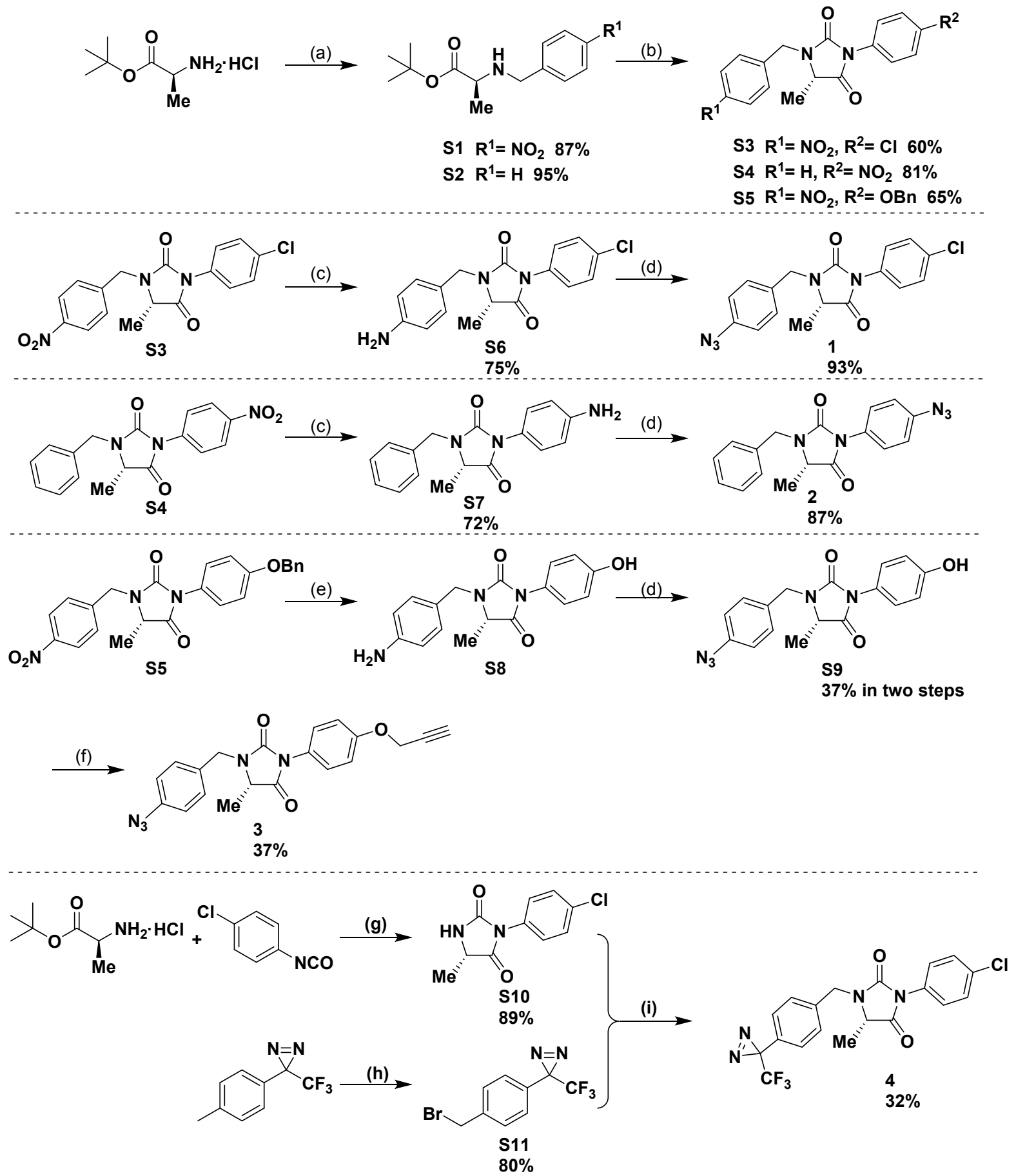

Reagents and Conditions: (a) benzyl bromide, DIPEA, $\mathrm{CH}_{3} \mathrm{CN}$; (b) i. phenyl isocyanate, $\mathrm{CH}_{3} \mathrm{CN}$, r.t., overnight; ii. $12 \mathrm{~N} \mathrm{HCl}$, r.t., 10 h; (c) Fe, $\mathrm{NH}_{4} \mathrm{Cl}, \mathrm{MeOH}, \mathrm{H}_{2} \mathrm{O}$; (d) $\mathrm{NaNO}_{2}$, $\mathrm{NaN}_{3}, 6 \mathrm{~N} \mathrm{HCl}, 0{ }^{\circ} \mathrm{C}$ to r.t., 1.5 h; (e) $\mathrm{H}_{2}, \mathrm{Pd} / \mathrm{C}, \mathrm{MeOH}$, overnight; (f) 3-bromopropyne, $\mathrm{K}_{2} \mathrm{CO}_{3}$, acetone, r.t., overnight; (g) i. 4-chlorophenyl isocyanate, $\mathrm{CH}_{3} \mathrm{CN}$, r.t., overnight; ii. $12 \mathrm{~N} \mathrm{HCl}$, r.t., 10 h; (h) NBS, AIBN, $\mathrm{CCl}_{4}$, reflux, 2h; (i) $\mathrm{Cs}_{2} \mathrm{CO}_{3}, \mathrm{CH}_{3} \mathrm{CN}$, r.t., overnight. 
Scheme S2. Synthesis of Allo-1 analogs
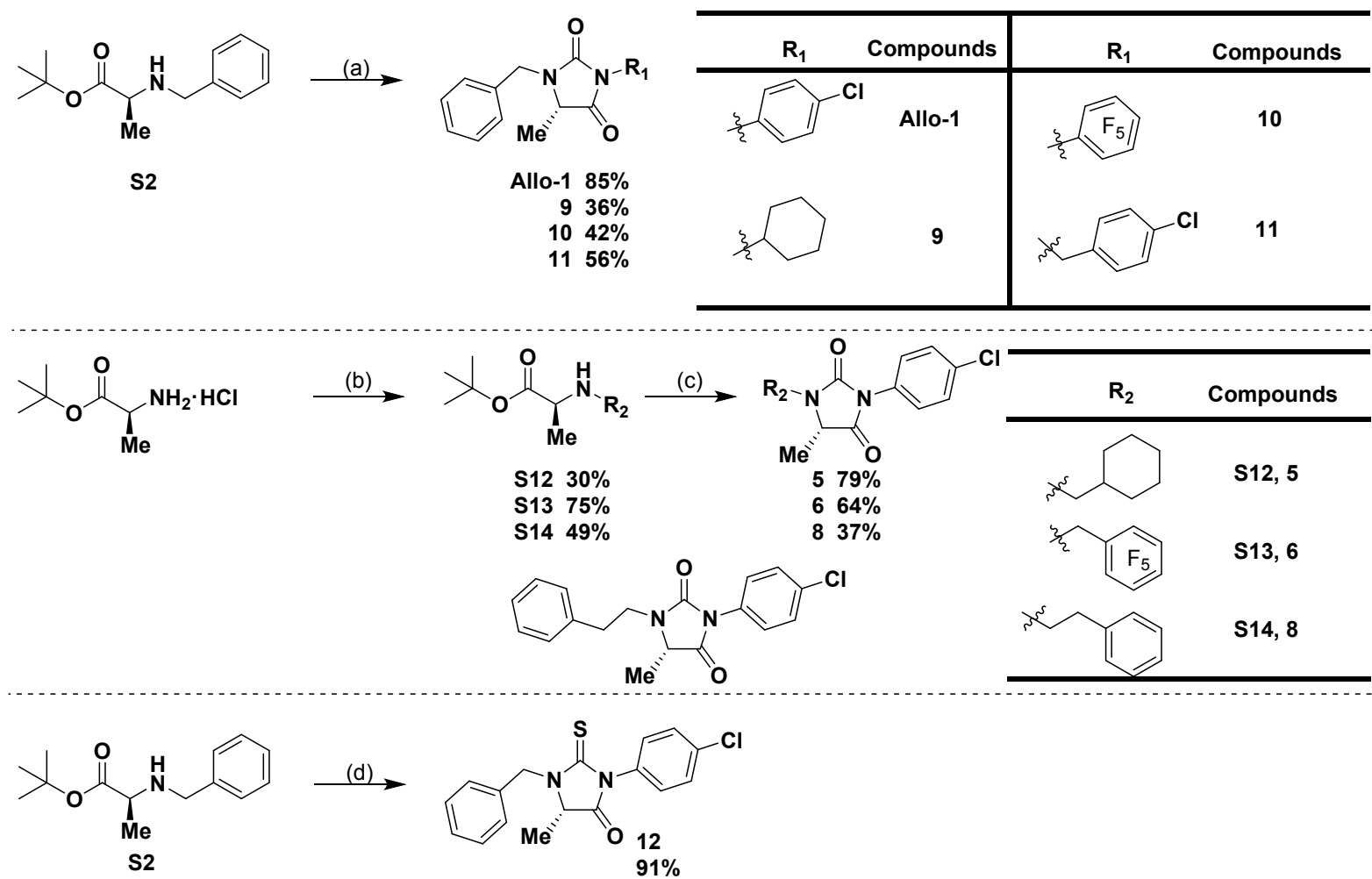

$>_{0} \underbrace{\mathrm{O}}_{\mathrm{Me}} \mathrm{NH}_{2} \cdot \mathrm{HCl}$<smiles>CC(C)(C)OC(=O)C(=O)NC(=O)c1ccccc1</smiles>
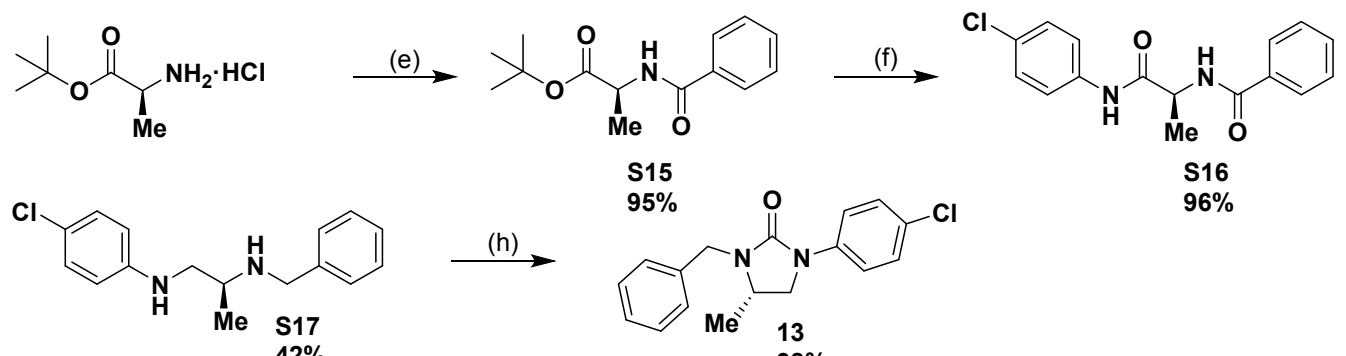

(h)

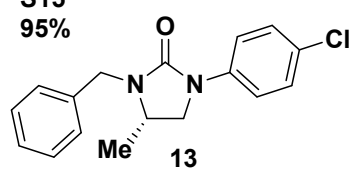

$96 \%$<smiles>CC(C)(C)OC(=O)C(N)NCl</smiles><smiles>C[13C](C)NC(Nc1ccccc1)C(=O)OC(C)(C)C</smiles>

Reagents and Conditions: (a) i. isocyanate, $\mathrm{CH}_{3} \mathrm{CN}$, r.t., overnight; ii. $12 \mathrm{~N} \mathrm{HCl}$, r.t., $10 \mathrm{~h}$; (b) $\mathrm{K}_{2} \mathrm{CO}_{3}$, alkyl bromides, $\mathrm{CH}_{3} \mathrm{CN}, 70{ }^{\circ} \mathrm{C}$, overnight; (c) i. 4-chlorophenyl isocyanate, $\mathrm{CH}_{3} \mathrm{CN}$, r.t., overnight; ii. $12 \mathrm{~N} \mathrm{HCl}$, r.t., 10 h; (d) i. 1-chloro-4-isothiocyanatobenzene, $\mathrm{CH}_{3} \mathrm{CN}$, r.t., overnight; ii. $12 \mathrm{~N} \mathrm{HCl}$, r.t., 10 h; (e) benzoyl chloride, $\mathrm{Et}_{3} \mathrm{~N}, \mathrm{CH}_{2} \mathrm{Cl}_{2}$, r.t., 2h; (f) i. TFA, $\mathrm{CH}_{2} \mathrm{Cl}_{2}$, r.t., 2h; ii. 4-chloroaniline, DIPEA, HATU, DMF, $70{ }^{\circ} \mathrm{C}, 4 \mathrm{~h}$; (g) LiAlH 4 , THF, $0{ }^{\circ} \mathrm{C}$ to reflux, overnight; (h) triphosgene, THF, r.t., 2 h; (i) phenylboronic acid, $\mathrm{O}_{2}, \mathrm{Cu}(\mathrm{OAc})_{2}$, $\mathrm{Et}_{3} \mathrm{~N}, 4 \AA$ molecular sieve, $\mathrm{CH}_{2} \mathrm{Cl}_{2}$ r.t., overnight. 
Scheme S3. Synthesis of BODIPY-LY for the competition assay with Allo-1

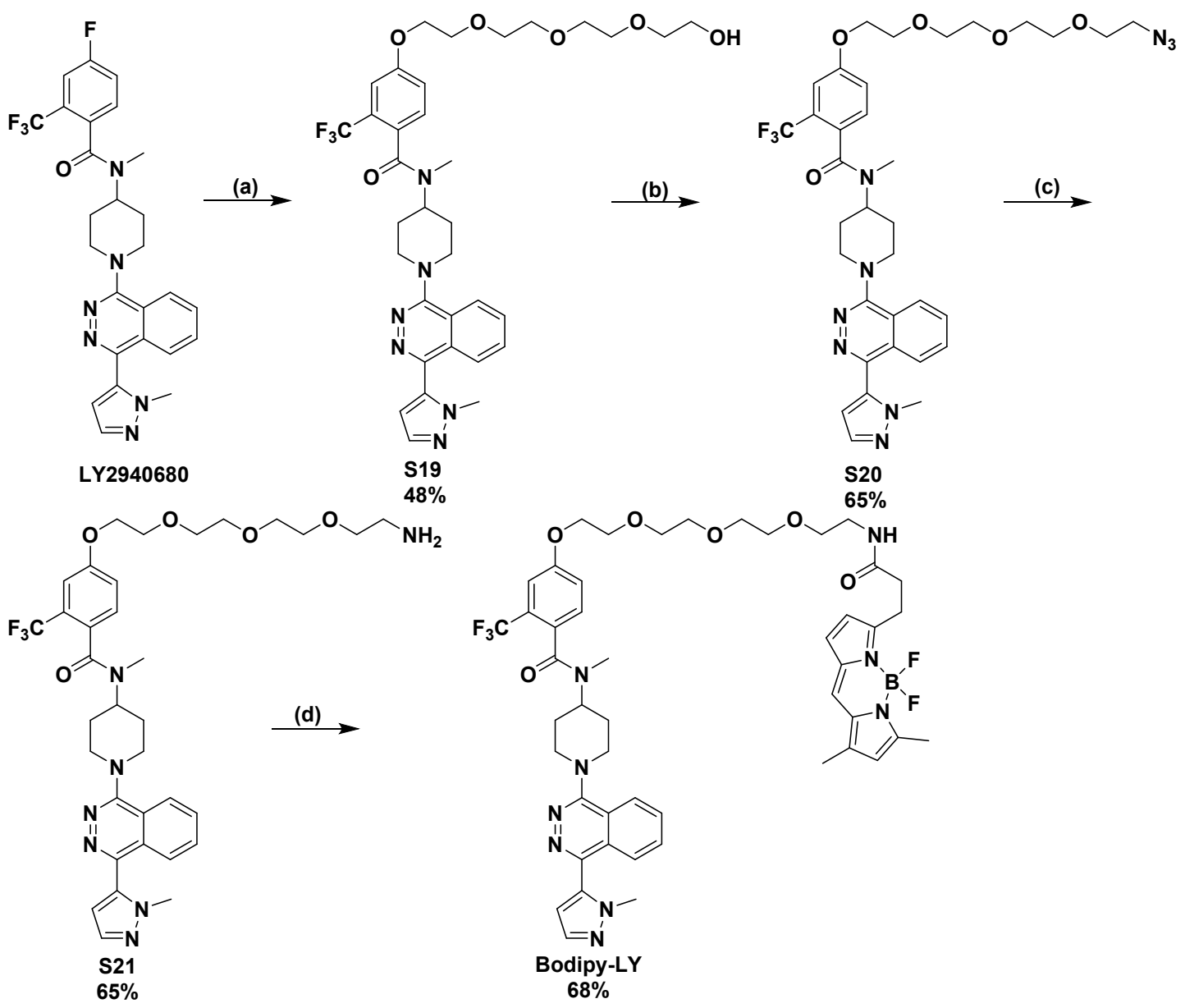

Reagents and Conditions: (a) tetraethylene glycol, $\mathrm{NaH}, \mathrm{DMF}, 120{ }^{\circ} \mathrm{C}$, overnight; (b) DPPA, DBU, THF, r.t. to reflux, 18-24 h; (c) $\mathrm{H}_{2}$, $\mathrm{Pd} / \mathrm{C}$, MeOH, r.t. 4 h; (d) Bodipy NHS ester, DIPEA, $\mathrm{CH}_{3} \mathrm{CN}, 1.5 \mathrm{~h}$. 


\section{Procedures for the synthesis of photoaffinity probe 1-4}

\section{General procedure for the synthesis of tert-butyl benzylalaninate (S1, S2)}

To a solution of tert-butyl $L$-alaninate hydrochloride (27.6 mmol, $5.0 \mathrm{~g}$ ) in $30 \mathrm{~mL} \mathrm{CH}{ }_{3} \mathrm{CN}$ was added DIPEA (55.2 mmol, $7.1 \mathrm{~g}$ ) and benzyl bromide $(24.8 \mathrm{mmol})$. After the mixture was stirred overnight at room temperature, the reaction was quenched with saturated $\mathrm{NaHCO}_{3}$ solution, extracted with EtOAc for three times. The combined organic layer was washed with saturated $\mathrm{NaHCO}_{3}$ solution and brine, dried over $\mathrm{Na}_{2} \mathrm{SO}_{4}$. The reaction was concentrated and purified by flash column chromatography (EtOAc/PE from 1:5 to 1:1) on silica gel to obtain $\mathbf{S 1}$ and $\mathbf{S 2}$ respectively.

\section{General procedure for the synthesis of hydatoin compounds (S3, S4 and S5)}

To a solution of tert-butyl benzylalaninate $(1.0 \mathrm{mmol})$ in $\mathrm{CH}_{3} \mathrm{CN}$ was added corresponding phenyl isocyanate. The reaction mixture was stirred at room temperature overnight, then 0.5 $\mathrm{mL}$ concentrated hydrochloric acid was added followed by another $10 \mathrm{~h}$ stirring. The reaction was quenched with saturated $\mathrm{NaHCO}_{3}$ solution, extracted with EtOAc for three times. The combined organic layer was washed with brine and dried over $\mathrm{Na}_{2} \mathrm{SO}_{4}$. The reaction was filtered, concentrated and purified with column chromatography (EtOAc/PE from 1:10 to 1:3) to obtain the S3, S4 and S5.

\section{General procedure for the synthesis of amine compounds (S6, S7)}

A solution of nitro containing Allo-1 analogs $(\mathbf{S 3}, \mathbf{S 4})(0.76 \mathrm{mmol})$ in $3 \mathrm{~mL} \mathrm{MeOH}$ and $1 \mathrm{~mL}$ $\mathrm{H}_{2} \mathrm{O}$ was added $\mathrm{Fe}(3.8 \mathrm{mmol}, 213 \mathrm{mg})$ and $\mathrm{NH}_{4} \mathrm{Cl}(7.6 \mathrm{mmol}, 420 \mathrm{mg})$. The reaction was stirred at $60{ }^{\circ} \mathrm{C}$ overnight. The reaction was quenched with saturated $\mathrm{NaHCO}_{3}$ solution, extracted with EtOAc for three times. The combined organic layer was washed with brine and dried over $\mathrm{Na}_{2} \mathrm{SO}_{4}$. The reaction was filtered, concentrated and purified with column chromatography (EtOAc/PE 1:3) to obtain the S6 and S7.

\section{General procedure for the synthesis of S8}

A solution of nitro containing Allo-1 analogs $\mathbf{S 5}(1.0 \mathrm{mmol})$ in $5 \mathrm{~mL} \mathrm{MeOH}$ was treated with $\mathrm{Pd} / \mathrm{C}(10 \mathrm{wt} \%)$ respectively. The reaction was degased under vacuum and filled with $\mathrm{H}_{2}$ atmosphere. The reaction was stirred at r.t. overnight before being filtered and concentrated for further use without purification.

\section{Synthesis of Compound S9}

S9 were obtained with the same procedure as the synthesis of compound $\mathbf{1}$ and $\mathbf{2}$.

\section{Synthesis of S10}


To a solution of $L$-alaninate hydrochloride $(1.6 \mathrm{mmol}, 300 \mathrm{mg})$ in $10 \mathrm{~mL} \mathrm{CH}_{3} \mathrm{CN}$ was added 4-chlorophenyl isocyanate $(1.8 \mathrm{mmol}, 280 \mathrm{mg})$ and $\mathrm{Et}_{3} \mathrm{~N}(2.5 \mathrm{mmol}, 250 \mathrm{mg})$. The reaction mixture was stirred at room temperature overnight before being treated with $0.5 \mathrm{~mL} 12 \mathrm{~N}$ hydrochloric acid, followed by another $10 \mathrm{~h}$ stirring. The reaction was quenched with saturated $\mathrm{NaHCO}_{3}$ solution, extracted with EtOAc for three times. The combined organic layer was washed with brine and dried over $\mathrm{Na}_{2} \mathrm{SO}_{4}$. The reaction was filtered, concentrated and purified with column chromatography (EtOAc/PE 1:3) to obtain $\mathbf{S 1 0}$.

\section{Synthesis of S11}

S11 was synthesized according to literature procedure with slight modification ${ }^{18}$.

\section{Synthesis of Compound 4}

To a solution of $\mathbf{S 1 0}(0.67 \mathrm{mmol}, 150 \mathrm{mg})$ and $\mathbf{S 1 1}(1.0 \mathrm{mmol}, 280 \mathrm{mg})$ in $5 \mathrm{~mL} \mathrm{CH}{ }_{3} \mathrm{CN}$ was added $\mathrm{Cs}_{2} \mathrm{CO}_{3}(0.89 \mathrm{mmol}, 200 \mathrm{mg})$. The mixture was stirred at room temperature overnight. The reaction was quenched with saturated $\mathrm{NH}_{4} \mathrm{Cl}$ solution and extracted with EtOAc for three times. The combined organic layer was washed with saturated $\mathrm{NH}_{4} \mathrm{Cl}$ solution and brine, dried over $\mathrm{Na}_{2} \mathrm{SO}_{4}$. Finally, the reaction was filtered, concentrated and purified with column chromatography (EtOAc/PE 1:5) to obtain compound 4. 


\section{Procedures for the synthesis of Allo-1 analogs to study the interaction between Allo-1 and SMO}

General procedure for the synthesis of Allo-1, compound 9, compound 10 and compound 11

Allo-1, compound 9, compound 10, and compound $\mathbf{1 1}$ were obtained with the same procedure as the synthesis of hydatoin compounds.

\section{Synthesis of compound 12}

To a solution of $\mathbf{S 2}(0.85 \mathrm{mmol}, 200 \mathrm{mg})$ in $2 \mathrm{~mL} \mathrm{CH} \mathrm{CH}_{3} \mathrm{CN}$ was added 1-chloro-4isothiocyanatobenzene $(0.71 \mathrm{mmol}, 120 \mathrm{mg})$. The reaction mixture was stirred at room temperature overnight. After adding $0.5 \mathrm{~mL}$ concentrated hydrochloric acid, the reaction was stirred for another $10 \mathrm{~h}$. The reaction was quenched with saturated $\mathrm{NaHCO}_{3}$ solution, extracted with EtOAc for three times. The combined organic layer was washed with saturated $\mathrm{NaHCO}_{3}$ solution and brine, dried over $\mathrm{Na}_{2} \mathrm{SO}_{4}$. The reaction was filtered, concentrated and purified with column chromatography (EtOAc/PE 1:5) to obtain compound 12.

\section{General procedure for the synthesis of S12, S13, S14}

To a solution of tert-butyl $L$-analinate hydrochloride $\left(2.8 \mathrm{mmol}, 509 \mathrm{mg}\right.$ ) in $\mathrm{CH}_{3} \mathrm{CN}, \mathrm{K}_{2} \mathrm{CO}_{3}$ ( $2.8 \mathrm{mmol}, 390 \mathrm{mg})$, and corresponding bromide $(2.2 \mathrm{mmol})$ was added. The reaction mixture was stirred at $70{ }^{\circ} \mathrm{C}$ overnight before being quenched with saturated $\mathrm{NH}_{4} \mathrm{Cl}$ solution. The reaction mixture was extracted with EtOAc for three times. The combined organic layer was washed with saturated $\mathrm{NH}_{4} \mathrm{Cl}$ solution and brine, dried over $\mathrm{Na}_{2} \mathrm{SO}_{4}$. Finally, the reaction was filtered, concentrated and purified with column chromatography (EtOAc/PE 1:1) to obtain S12, S13 and S14.

\section{General procedure for the synthesis of compound 5, compound 6 and compound 8}

Compound 5, compound $\mathbf{6}$ and compound $\mathbf{8}$ were obtained with the same procedure as the synthesis of hydatoin compounds.

\section{Synthesis of S15}

To a solution of tert-butyl $L$-analinate hydrochloride (5.5 mmol, $1.0 \mathrm{~g}), \mathrm{NEt}_{3}(11 \mathrm{mmol} 1.1 \mathrm{~g}$ ) in $8 \mathrm{~mL}$ anhydrous $\mathrm{CH}_{2} \mathrm{Cl}_{2}$, benzoyl chloride $(6.0 \mathrm{mmol}, 856 \mathrm{mg})$ in $8 \mathrm{~mL} \mathrm{CH}_{2} \mathrm{Cl}_{2}$ was added. The reaction mixture was stirred for $6 \mathrm{~h}$ at room temperature before being quenched with saturated $\mathrm{NH}_{4} \mathrm{Cl}$ solution. The reaction was extracted with EtOAc for three times and washed with saturated $\mathrm{NH}_{4} \mathrm{Cl}$ solution and brine sequentially, dried over $\mathrm{Na}_{2} \mathrm{SO}_{4}$. The reaction was filtered, concentrated and purified with column chromatography (EtOAc/PE 1:3) to obtain S15. 


\section{Synthesis of S16}

To a solution of $\mathbf{S 1 5}(2.6 \mathrm{mmol}, 655 \mathrm{mg})$ in $5 \mathrm{~mL} \mathrm{CH}_{2} \mathrm{Cl}_{2}$ was added $2 \mathrm{~mL}$ TFA. The mixture was stirred at room temperature for $4 \mathrm{~h}$ and then concentrated for further use. The reaction was added a solution of 4-chloroaniline ( $2.9 \mathrm{mmol}, 365 \mathrm{mg}), 2$-(7-aza- $1 H$-benzotriazole-1-yl)1,1,3,3-tetramethyluronium hexafluorophosphate (3.1 mmol, $1.2 \mathrm{~g}$ ), DIPEA (5.2 mmol, 860 $\mathrm{uL}$ ) in $5 \mathrm{~mL}$ DMF. The reaction was stirred at $70{ }^{\circ} \mathrm{C}$ for $4 \mathrm{~h}$ before being quenched with saturated $\mathrm{NH}_{4} \mathrm{Cl}$ solution. The reaction was extracted with EtOAc for three times and washed with saturated $\mathrm{NH}_{4} \mathrm{Cl}$ solution and brine sequentially, dried over $\mathrm{Na}_{2} \mathrm{SO}_{4}$. The reaction was filtered, concentrated and purified with column chromatography (EtOAc/PE 1:5) to obtain S16.

\section{Synthesis of S17}

To a solution of S16 (2.0 mmol, $604 \mathrm{mg})$ in anhydrous THF was slowly added $\mathrm{LiAlH}_{4}(4.0$ mmol, $152 \mathrm{mg}$ ). The reaction was refluxed overnight before being quenched with $\mathrm{NaHCO}_{3}$ solution. The mixture was extracted with EtOAc for three times and washed with saturated $\mathrm{NaHCO}_{3}$ solution and brine, dried over $\mathrm{Na}_{2} \mathrm{SO}_{4}$. The reaction was filtered, concentrated and purified with column chromatography (MeOH/DCM 1:20) to obtain S17.

\section{Synthesis of compound 13}

To a solution of $\mathbf{S 1 7}(0.07 \mathrm{mmol}, 20 \mathrm{mg})$ in anhydrous THF was added triphosgene $(0.05 \mathrm{mmol}$, $15 \mathrm{mg}$ ). The mixture was stirred at r.t. for $1 \mathrm{~h}$ before the reaction was concentrated and then purified with column chromatography (EtOAc/PE 1:5) to obtain compound $\mathbf{1 3}$.

\section{Synthesis of S18}

To a mixture of tert-butyl $L$-analinate hydrochloride $(5 \mathrm{mmol}, 905 \mathrm{mg})$, phenylboronic acid $(10.0 \mathrm{mmol}, 1.2 \mathrm{~g}), \mathrm{Cu}(\mathrm{OAc})_{2}(5.5 \mathrm{mmol}, 990 \mathrm{mg})$ and $4 \AA$ molecular sieve in $\mathrm{CH}_{2} \mathrm{Cl}_{2}$ under $\mathrm{O}_{2}$, was added a solution of $\mathrm{Et}_{3} \mathrm{~N}(10.0 \mathrm{mmol}, 1.0 \mathrm{~g})$ in $\mathrm{CH}_{2} \mathrm{Cl}_{2}$. The mixture was stirred at room temperature overnight before being quenched with saturated $\mathrm{NH}_{4} \mathrm{Cl}$ solution. The reaction was extracted with EtOAc for three times and washed with saturated $\mathrm{NH}_{4} \mathrm{Cl}$ solution and brine, dried over $\mathrm{Na}_{2} \mathrm{SO}_{4}$. The reaction was filtered, concentrated and purified with column chromatography (EtOAc/PE 1:5) to obtain $\mathbf{S 1 8 .}$

\section{Synthesis of compound 7}

Compound 7 was obtained with the same procedure as the synthesis of hydatoin compounds. 


\section{Procedures for the synthesis of BODIPY-LY}

\section{Synthesis of S19}

To a solution of tetraethylene glycol $(3.0 \mathrm{mmol}, 582 \mathrm{mg})$ in $10 \mathrm{~mL}$ DMF was added $60 \%$ sodium hydride $(1.5 \mathrm{mmol}, 60 \mathrm{mg})$. The reaction mixture was stirred at room temperature for $30 \mathrm{~min}$ before LY2940680 (1.0 mmol, $512 \mathrm{mg}$ ) was added. The reaction mixture was heated at $120{ }^{\circ} \mathrm{C}$ and stirred overnight. The reaction was cooled and quenched by the addition of saturated $\mathrm{NH}_{4} \mathrm{Cl}$ solution. The reaction mixture was extracted 3 times with $\mathrm{CH}_{2} \mathrm{Cl}_{2}$. The combined organic layer was washed with saturated $\mathrm{NH}_{4} \mathrm{Cl}$ solution and brine sequentially, dried over $\mathrm{Na}_{2} \mathrm{SO}_{4}$. After filtration, the solution was concentrated in vacuum and the crude product was purified by flash column chromatography (MeOH/DCM 1:7) on silica gel to obtain S19.

\section{Synthesis of S20}

To a solution of $\mathbf{S 1 9}(0.5 \mathrm{mmol}, 343 \mathrm{mg})$ in $5 \mathrm{~mL}$ THF was added Diphenylphosphoryl azide (DPPA, $2.0 \mathrm{mmol}, 550 \mathrm{mg}$ ) and 1,8-diazabicyclo[5,4,0]-7-undecene (DBU, $1.5 \mathrm{mmol}, 228 \mathrm{mg}$ ). The reaction mixture was stirred at room temperature overnight and then heat at reflux for 6 hours. The reaction was quenched by the addition of brine. The reaction mixture was extracted 3 times with $\mathrm{CH}_{2} \mathrm{Cl}_{2}$. The combined organic layer was washed with brine, dried over $\mathrm{Na}_{2} \mathrm{SO}_{4}$. After filtration, the solution was concentrated in vacuum and the crude product was purified by flash column chromatography (MeOH/DCM 1:10) on silica gel to obtain $\mathbf{S 2 0}$.

\section{Synthesis of S21}

A solution of $\mathbf{S 2 0}(0.035 \mathrm{mmol}, 25 \mathrm{mg})$ in $5 \mathrm{~mL} \mathrm{MeOH}$ was treated with $\mathrm{Pd} / \mathrm{C}(10 \mathrm{wt} \%)$. The reaction was degased under vacuum and filled with $\mathrm{H}_{2}$ atmosphere. The reaction was stirred at r.t. overnight. After that, the reaction was filtered and concentrated for further use.

\section{Synthesis of BODIPY-LY}

To a solution of $\mathbf{S 2 1}(0.014 \mathrm{mmol}, 10 \mathrm{mg})$ and Bodipy NHS ester $(0.015 \mathrm{mmol}, 6 \mathrm{mg})$ in $1 \mathrm{~mL}$ $\mathrm{CH}_{3} \mathrm{CN}$ was added DIPEA $(0.014 \mathrm{mmol}, 2.5 \mathrm{ul})$. The reaction was stirred at room temperature for $1.5 \mathrm{~h}$ before being quenched with saturated $\mathrm{NH}_{4} \mathrm{Cl}$ solution. The reaction was extracted with EtOAc for three times and washed with saturated $\mathrm{NH}_{4} \mathrm{Cl}$ solution and brine sequentially, dried over $\mathrm{Na}_{2} \mathrm{SO}_{4}$. The organic layer was combined and filtered, concentrated and purified by $\mathrm{HPLC}\left(\mathrm{CH}_{3} \mathrm{CN} / \mathrm{H}_{2} \mathrm{O}\right.$, gradient elution) to obtain BODIPY-LY. 
(S)-3-(4-chlorophenyl)-5-methyl-1-(4-(3-(trifluoromethyl)-3H-diazirin-3-

yl)benzyl)imidazolidine-2,4-dione (Compound 4), white solid. ${ }^{1} \mathrm{H}$ NMR (500 $\mathrm{MHz}$, Chloroform- $d$ ), $\delta$ (ppm) 7.45-7.42 (m, 4H), $7.38(\mathrm{~d}, J=8.0 \mathrm{~Hz}, 2 \mathrm{H}), 7.21(\mathrm{~d}, J=8.0 \mathrm{~Hz}, 2 \mathrm{H})$, $5.00(\mathrm{~d}, J=15.4 \mathrm{~Hz}, 1 \mathrm{H}), 4.30(\mathrm{~d}, J=15.4 \mathrm{~Hz}, 1 \mathrm{H}), 3.94$ (q, $J=6.9 \mathrm{~Hz}, 1 \mathrm{H}), 1.47$ (d, $J=6.9$ $\mathrm{Hz}, 3 \mathrm{H}) .{ }^{13} \mathrm{C}$ NMR (126 MHz, Chloroform- $d$ ), $\delta$ (ppm) 171.9, 155.0, 137.5, 133.9, 130.3, 129.4, 129.3, 128.7, 127.3, 127.1, 55.0, 44.5, 15.6. HRMS calcd for $\mathrm{C}_{19} \mathrm{H}_{14} \mathrm{ClF}_{3} \mathrm{~N}_{4} \mathrm{O}_{2}[\mathrm{M}+\mathrm{H}]^{+}$: 423.0836; found: 423.0832. HPLC: $t_{\mathrm{R}} 11.9 \mathrm{~min}$, purity $>95 \%$.

(S)-3-(4-chlorophenyl)-1-(cyclohexylmethyl)-5-methylimidazolidine-2,4-dione

(Compound 5), white solid. ${ }^{1} \mathrm{H}$ NMR (800 MHz, Chloroform- $d$ ), $\delta$ (ppm) 7.41 (m, 4H), 4.09 $(\mathrm{q}, J=7.0 \mathrm{~Hz}, 1 \mathrm{H}), 3.54(\mathrm{~m}, 1 \mathrm{H}), 3.01(\mathrm{~m}, 1 \mathrm{H}), 1.80-1.58(\mathrm{~m}, 6 \mathrm{H}), 1.52(\mathrm{~d}, J=7.0 \mathrm{~Hz}, 3 \mathrm{H})$, 1.29-1.17 (m, 3H), 1.08-0.94 (m, 2H). ${ }^{13} \mathrm{C}$ NMR (201 MHz, Chloroform- $d$ ), $\delta$ (ppm) 172.4, 154.8, 133.5, 130.4, 129.1, 127.0, 55.5, 47.0, 36.4, 30.9, 30.6, 26.2, 25.7, 25.6, 15.5. HRMS calcd for $\mathrm{C}_{17} \mathrm{H}_{21} \mathrm{ClN}_{2} \mathrm{O}_{2}[\mathrm{M}+\mathrm{H}]^{+}: 321.1370$; found: 321.1368 . HPLC: $t_{\mathrm{R}} 11.4$ min, purity $>95 \%$. (S)-3-(4-chlorophenyl)-5-methyl-1-((perfluorophenyl)methyl)imidazolidine-2,4-dione (Compound 6), white solid. ${ }^{1} \mathrm{H}$ NMR (500 MHz, Chloroform- $d$ ), $\delta$ (ppm) 7.42-7.26 (m, 4H), $5.14(\mathrm{~d}, J=15.3,1 \mathrm{H}), 4.40(\mathrm{~d}, J=15.3,1 \mathrm{H}), 4.00(\mathrm{q}, J=6.9 \mathrm{~Hz}, 1 \mathrm{H}), 1.59$ (d, $J=6.9 \mathrm{~Hz}, 3 \mathrm{H})$. ${ }^{13} \mathrm{C}$ NMR (126 MHz, Chloroform- $d$ ), $\delta$ (ppm) 171.5, 154.3, 134.0, 130.1, 129.3, 129.1, 127.1, 55.3, 32.5, 15.5. HRMS calcd for $\mathrm{C}_{17} \mathrm{H}_{10} \mathrm{ClF}_{5} \mathrm{~N}_{2} \mathrm{O}_{2}[\mathrm{M}+\mathrm{H}]^{+}:$405.0429; found: 405.0428. HPLC: $t_{\mathrm{R}} 11.5 \mathrm{~min}$, purity $>95 \%$.

(S)-3-(4-chlorophenyl)-5-methyl-1-phenylimidazolidine-2,4-dione (Compound 7), white solid. ${ }^{1} \mathrm{H}$ NMR (500 MHz, Chloroform- $d$ ), $\delta(\mathrm{ppm})$ 7.50-7.40 (m, 8H), 7.30-7.22 (m, 1H), 4.73 $(\mathrm{q}, J=6.9 \mathrm{~Hz}, 1 \mathrm{H}), 1.57(\mathrm{~d}, J=6.9 \mathrm{~Hz}, 3 \mathrm{H}) .{ }^{13} \mathrm{C}$ NMR $(126 \mathrm{MHz}$, Chloroform- $d), \delta$ (ppm) 171.5, 152.8, 135.4, 134.1, 130.1, 129.6, 129.4, 127.5, 126.0, 122.3, 56.2, 16.0. HRMS calcd for $\mathrm{C}_{16} \mathrm{H}_{13} \mathrm{ClN}_{2} \mathrm{O}_{2}[\mathrm{M}+\mathrm{H}]^{+}:$301.0744; found: 301.0741 . HPLC: $t_{\mathrm{R}} 11.3 \mathrm{~min}$, purity $>95 \%$.

(S)-3-(4-chlorophenyl)-5-methyl-1-phenethylimidazolidine-2,4-dione (Compound 8), white solid. ${ }^{1} \mathrm{H}$ NMR (500 MHz, Chloroform- $d$ ), $\delta(\mathrm{ppm})$ 7.36-7.28 (m, 4H), 7.26-7.24 (m, 2H), 7.20-7.15 (m, 3H), 3.92-3.86 (m, 1H), 3.79 (q, $J=7.0 \mathrm{~Hz}, 1 \mathrm{H}), 3.38-3.31(\mathrm{~m}, 1 \mathrm{H}), 2.95-$ $2.83(\mathrm{~m}, 2 \mathrm{H}), 1.34(\mathrm{~d}, J=7.0 \mathrm{~Hz}, 3 \mathrm{H}) .{ }^{13} \mathrm{C}$ NMR (126 MHz, Chloroform- $d$ ), $\delta$ (ppm) 172.3, 154.6, 138.1, 133.7, 130.4, 129.3, 128.9, 128.8, 127.2, 127.1, 55.7, 42.6, 34.5, 15.5. HRMS calcd for $\mathrm{C}_{18} \mathrm{H}_{17} \mathrm{ClN}_{2} \mathrm{O}_{2}[\mathrm{M}+\mathrm{H}]^{+}: 329.1057$; found: 329.1055 . HPLC: $t_{\mathrm{R}} 11.4$ min, purity $>95 \%$. (S)-1-benzyl-3-cyclohexyl-5-methylimidazolidine-2,4-dione (Compound 9), white solid. ${ }^{1} \mathrm{H}$ NMR (500 MHz, Chloroform- $d$ ), $\delta(\mathrm{ppm})$ 7.37-7.28 (m, 3H), 7.27-7.21 (m, 2H), 4.94 (d, $J=$ $15.3 \mathrm{~Hz}, 1 \mathrm{H}), 4.14$ (d, $J=15.3 \mathrm{~Hz}, 1 \mathrm{H}), 3.96-3.89$ (m, 1H), 3.69 (q, $J=7.0 \mathrm{~Hz}, 1 \mathrm{H}), 2.19-2.10$ $(\mathrm{m}, 2 \mathrm{H}), 1.84-1.82(\mathrm{~m}, 2 \mathrm{H}), 1.70-1.64(\mathrm{~m}, 3 \mathrm{H}), 1.33-1.21(\mathrm{~m}, 6 \mathrm{H}) .{ }^{13} \mathrm{C}$ NMR $(126 \mathrm{MHz}$, Chloroform- $d$ ), $\delta$ (ppm) 173.8, 156.4, 136.1, 129.0, 128.2, 128.1, 54.3, 51.8, 44.7, 29.56, 29.53, 26.0, 25.98, 25.2, 15.4. HRMS calcd for $\mathrm{C}_{17} \mathrm{H}_{22} \mathrm{~N}_{2} \mathrm{O}_{2}[\mathrm{M}+\mathrm{H}]^{+}:$287.1760; found: 287.1757. HPLC: $t_{\mathrm{R}} 11.6 \mathrm{~min}$, purity $>95 \%$.

(S)-1-benzyl-5-methyl-3-(perfluorophenyl)imidazolidine-2,4-dione (Compound 10), white 
solid. ${ }^{1} \mathrm{H}$ NMR (500 MHz, Chloroform- $d$ ), $\delta(\mathrm{ppm})$ 7.42-7.33 (m, 3H), 7.32-7.28 (m, 2H), 5.07 $(\mathrm{d}, J=15.3 \mathrm{~Hz}, 1 \mathrm{H}), 4.24(\mathrm{~d}, J=15.3 \mathrm{~Hz}, 1 \mathrm{H}), 4.05(\mathrm{~d}, J=7.0 \mathrm{~Hz}, 1 \mathrm{H}), 1.50(\mathrm{~d}, J=7.0 \mathrm{~Hz}$, $3 \mathrm{H}) .{ }^{13} \mathrm{C}$ NMR (126 MHz, Chloroform- $d$ ), $\delta$ (ppm) 170.9, 152.9, 135.0, 129.3, 128.6, 128.2, 55.6, 45.2, 15.5. HRMS calcd for $\mathrm{C}_{17} \mathrm{H}_{11} \mathrm{~F}_{5} \mathrm{~N}_{2} \mathrm{O}_{2}[\mathrm{M}+\mathrm{H}]^{+}:$371.0819; found: 371.0819. HPLC: $t_{\mathrm{R}} 11.5 \mathrm{~min}$, purity $>95 \%$.

(S)-1-benzyl-3-(4-chlorobenzyl)-5-methylimidazolidine-2,4-dione (Compound 11), white solid. ${ }^{1} \mathrm{H}$ NMR (500 MHz, Chloroform- $d$ ), $\delta(\mathrm{ppm})$ 7.36-7.29 (m, 7H), 7.24-7.22 (m, 2H), 4.96 $(\mathrm{d}, J=15.2 \mathrm{~Hz}, 1 \mathrm{H}), 4.64$ (q, $J=14.5 \mathrm{~Hz}, 2 \mathrm{H}), 4.14$ (d, $J=15.2 \mathrm{~Hz}, 1 \mathrm{H}), 3.78$ (q, $J=7.0 \mathrm{~Hz}$, $1 \mathrm{H}), 1.34(\mathrm{~d}, J=7.0 \mathrm{~Hz}, 3 \mathrm{H}) .{ }^{13} \mathrm{C}$ NMR (126 MHz, Chloroform- $d$ ), $\delta$ (ppm) 173.3, 156.0, 135.7, 134.8, 134.0, 130.2, 129.1, 129.0, 128.3, 128.2, 55.0, 44.8, 42.0, 15.2. HRMS calcd for $\mathrm{C}_{18} \mathrm{H}_{17} \mathrm{ClN}_{2} \mathrm{O}_{2},[\mathrm{M}+\mathrm{H}]^{+}: 329.1057$; found: 329.1055 . HPLC: $t_{\mathrm{R}} 11.5$ min, purity $>95 \%$.

(S)-1-benzyl-3-(4-chlorophenyl)-5-methyl-2-thioxoimidazolidin-4-one (Compound 12), white solid. ${ }^{1} \mathrm{H}$ NMR (800 MHz, Chloroform- $d$ ), $\delta$ (ppm) 7.62 (d, $\left.J=8.2 \mathrm{~Hz}, 2 \mathrm{H}\right), 7.40-7.35$ $(\mathrm{m}, 5 \mathrm{H}), 7.30(\mathrm{~d}, J=8.2 \mathrm{~Hz}, 2 \mathrm{H}), 5.77(\mathrm{~d}, J=15.1 \mathrm{~Hz}, 1 \mathrm{H}), 4.64$ (d, $J=15.1 \mathrm{~Hz}, 1 \mathrm{H}), 4.06$ (q, $J=7.0 \mathrm{~Hz}, 1 \mathrm{H}), 1.53$ (d, $J=7.0 \mathrm{~Hz}, 3 \mathrm{H}) ;{ }^{13} \mathrm{C}$ NMR (201 MHz, Chloroform- $d$ ), $\delta$ (ppm) 182.1, 173.3, 135.2, 134.8, 131.9, 129.9, 129.4, 129.2, 128.6, 128.4, 57.3, 48.7, 15.4. HRMS calcd for $\mathrm{C}_{17} \mathrm{H}_{15} \mathrm{ClN}_{2} \mathrm{OS}[\mathrm{M}+\mathrm{H}]^{+}:$331.0666; found: 331.0666. HPLC: $t_{\mathrm{R}} 11.7 \mathrm{~min}$, purity $>95 \%$.

(S)-3-benzyl-1-(4-chlorophenyl)-4-methylimidazolidin-2-one (Compound 13), white solid. ${ }^{1} \mathrm{H}$ NMR (800 MHz, Chloroform- $d$ ), $\delta$ (ppm) 7.53-7.52 (m, 2H), 7.34-7.31 (m, 4H), 7.29-7.28 $(\mathrm{m}, 3 \mathrm{H}), 4.85$ (d, $J=15.3 \mathrm{~Hz}, 1 \mathrm{H}), 4.15(\mathrm{~d}, J=15.3 \mathrm{~Hz}, 1 \mathrm{H}), 3.86$ (t, $J=8.7 \mathrm{~Hz}, 1 \mathrm{H}), 3.65-$ $3.62(\mathrm{~m}, 1 \mathrm{H}), 3.34-3.32(\mathrm{~m}, 1 \mathrm{H}), 1.27(\mathrm{~d}, J=6.2 \mathrm{~Hz}, 3 \mathrm{H}) .{ }^{13} \mathrm{C}$ NMR $(201 \mathrm{MHz}$, Chloroformd), $\delta$ (ppm) 157.4, 139.3, 137.1, 128.9, 128.8, 128.3, 127.7, 127.4, 118.6, 50.3, 47.4, 45.4, 18.9. HRMS calcd for $\mathrm{C}_{17} \mathrm{H}_{17} \mathrm{ClN}_{2} \mathrm{O},[\mathrm{M}+\mathrm{H}]^{+}:$301.1108; found: 301.1108. HPLC: $t_{\mathrm{R}} 12.0 \mathrm{~min}$, purity $>95 \%$.

(S)-3-(4-chlorophenyl)-5-methyl-1-(4-nitrobenzyl)imidazolidine-2,4-dione (S3), white solid. ${ }^{1} \mathrm{H}$ NMR (500 MHz, Chloroform- $d$ ), $\delta$ (ppm) 8.26 (d, $\left.J=8.7 \mathrm{~Hz}, 2 \mathrm{H}\right), 7.52$ (d, $J=8.7$ $\mathrm{Hz}, 2 \mathrm{H}), 7.46-7.42(\mathrm{~m}, 4 \mathrm{H}), 5.00(\mathrm{~d}, J=15.8 \mathrm{~Hz}, 1 \mathrm{H}), 4.49$ (d, $J=15.8 \mathrm{~Hz}, 1 \mathrm{H}), 4.01$ (q, $J=$ $7.0 \mathrm{~Hz}, 1 \mathrm{H}), 1.49$ (d, $J=7.0 \mathrm{~Hz}, 3 \mathrm{H}) ;{ }^{13} \mathrm{C}$ NMR (126 MHz, Chloroform- $d$ ), $\delta$ (ppm) 171.6, 155.0, 147.9, 143.0, 134.0, 130.0, 129.3, 128.9, 127.0, 124.3, 55.3, 44.5, 15.6. HRMS calcd for $\mathrm{C}_{17} \mathrm{H}_{14} \mathrm{ClN}_{3} \mathrm{O}_{4},[\mathrm{M}+\mathrm{H}]^{+}: 360.0751$; found: 360.0751 .

(S)-3-(4-(benzyloxy)phenyl)-5-methyl-1-(4-nitrobenzyl)imidazolidine-2,4-dione (S5) , yellow solid. ${ }^{1} \mathrm{H}$ NMR (800 MHz, Chloroform- $d$ ), $\delta(\mathrm{ppm}) 8.25(\mathrm{~d}, J=8.7 \mathrm{~Hz}, 2 \mathrm{H}), 7.52(\mathrm{~d}, J$ $=8.7 \mathrm{~Hz}, 2 \mathrm{H}), 7.43-7.42(\mathrm{~m}, 2 \mathrm{H}), 7.38-7.40(\mathrm{~m}, 2 \mathrm{H}), 7.34-7.33(\mathrm{~m}, 3 \mathrm{H}), 7.06(\mathrm{~d}, J=8.9 \mathrm{~Hz}$, 2H), $5.09(\mathrm{~s}, 2 \mathrm{H}), 4.98(\mathrm{~d}, J=15.8 \mathrm{~Hz}, 1 \mathrm{H}), 4.48(\mathrm{~d}, J=15.8 \mathrm{~Hz}, 1 \mathrm{H}), 3.99(\mathrm{q}, J=6.9 \mathrm{~Hz}$, $1 \mathrm{H}), 1.48(\mathrm{~d}, J=6.9 \mathrm{~Hz}, 3 \mathrm{H}) .{ }^{13} \mathrm{C}$ NMR (126 MHz, Chloroform- $d$ ), $\delta$ (ppm) 172.2, 158.6, 155.8, 148.0, 143.4, 136.7, 129.0, 128.8, 128.2, 127.6, 127.5, 124.5, 124.4, 115.5, 70.4, 55.5, 44.6, 15.8. HRMS calcd for $\mathrm{C}_{24} \mathrm{H}_{21} \mathrm{~N}_{3} \mathrm{O}_{5}[\mathrm{M}+\mathrm{H}]^{+}$: 432.1559 ; found: 432.1553 . 
(S)-1-(4-aminobenzyl)-3-(4-chlorophenyl)-5-methylimidazolidine-2,4-dione (S6), yellow solid. ${ }^{1} \mathrm{H}$ NMR (500 MHz, Chloroform- $d$ ), $\delta$ (ppm) 7.44-7.40 (m, 4H), 7.10 (d, J=8.2 Hz, 2H), $6.67(\mathrm{~d}, J=8.2 \mathrm{~Hz}, 2 \mathrm{H}), 4.98(\mathrm{~d}, J=15.0 \mathrm{~Hz}, 1 \mathrm{H}), 4.06$ (d, $J=15.0 \mathrm{~Hz}, 1 \mathrm{H}), 3.93(\mathrm{q}, J=7.0$ $\mathrm{Hz}, 1 \mathrm{H}), 3.73(\mathrm{~s}, 2 \mathrm{H}), 1.47$ (d, $J=7.0 \mathrm{~Hz}, 3 \mathrm{H}) ;{ }^{13} \mathrm{C}$ NMR (126 MHz, Chloroform- $d$ ), $\delta$ (ppm) $172.5,154.8,146.6,133.7,130.5,129.8,129.3,127.2,125.1,115.5,54.4,44.5,15.4$. HRMS calcd for $\mathrm{C}_{17} \mathrm{H}_{16} \mathrm{ClN}_{3} \mathrm{O}_{2}[\mathrm{M}+\mathrm{H}]^{+}: 330.1004$; found: 330.1012 .

(S)-3-(4-chlorophenyl)-5-methylimidazolidine-2,4-dione (S10), white solid. ${ }^{1} \mathrm{H}$ NMR (500 MHz, Chloroform- $d$ ), $\delta$ (ppm) 7.46-7.43 (m, 2H), 7.40-7.389 (m, 2H), 6.39 (s, 1H), 4.26 (q, $J$ $=7.0 \mathrm{~Hz}, 1 \mathrm{H}), 1.55(\mathrm{~d}, J=7.0 \mathrm{~Hz}, 3 \mathrm{H}) ;{ }^{13} \mathrm{C}$ NMR (126 MHz, Chloroform- $d$ ), $\delta$ (ppm) 173.3, 156.1, 134.1, 130.1, 129.4, 127.4, 53.0, 28.7, 17.9. HRMS calcd for $\mathrm{C}_{10} \mathrm{H}_{9} \mathrm{ClN}_{2} \mathrm{O}_{2}[\mathrm{M}+\mathrm{H}]^{+}$: 225.0425; found: 225.0422 .

tert-butyl (cyclohexylmethyl)-L-alaninate (S12), white solid. ${ }^{1} \mathrm{H}$ NMR $(500 \mathrm{MHz}$, Chloroform- $d$ ), $\delta$ (ppm) 3.14 (q, $J=6.9 \mathrm{~Hz}, 1 \mathrm{H}), 2.41-2.28$ (m, 2H), 1.80-1.59 (m, 6H), 1.45 $(\mathrm{s}, 9 \mathrm{H}), 1.46-1.32(\mathrm{~m}, 1 \mathrm{H}), 1.29-1.08(\mathrm{~m}, 5 \mathrm{H}), 0.98-0.81(\mathrm{~m}, 2 \mathrm{H}) .{ }^{13} \mathrm{C}$ NMR $(126 \mathrm{MHz}$, Chloroform- $d$ ), $\delta$ (ppm) 175.3, 80.6, 57.5, 54.7, 38.2, 31.5, 31.2, 28.0, 26.5, 26.0, 25.9, 19.0. HRMS calcd for $\mathrm{C}_{14} \mathrm{H}_{27} \mathrm{NO}_{2}[\mathrm{M}+\mathrm{H}]^{+}: 242.2120$; found: 242.2119 .

tert-butyl phenethyl-L-alaninate (S14), colorless oil. ${ }^{1} \mathrm{H}$ NMR $(500 \mathrm{MHz}$, Chloroform- $d)$, $\delta$ (ppm) 7.29 (td, $J=7.2,1.6 \mathrm{~Hz}, 2 \mathrm{H}), 7.23-7.17$ (m, 3H), 3.23 (q, $J=7.0 \mathrm{~Hz}, 1 \mathrm{H}), 2.90-2.81$ (m, $2 \mathrm{H}), 2.79-2.72(\mathrm{~m}, 2 \mathrm{H}), 1.43(\mathrm{~s}, 9 \mathrm{H}), 1.24(\mathrm{~d}, J=7.0 \mathrm{~Hz}, 3 \mathrm{H}) .{ }^{13} \mathrm{C}$ NMR $(126 \mathrm{MHz}$, Chloroform- $d$ ), $\delta$ (ppm) 174.8, 139.7, 128.5, 128.3, 126.0, 80.7, 57.2, 49.1, 36.5, 27.9, 18.9 . HRMS calcd for $\mathrm{C}_{15} \mathrm{H}_{23} \mathrm{NO}_{2}[\mathrm{M}+\mathrm{H}]^{+}: 250.1807$; found: 250.1808 .

(S)-N2-benzyl-N1-(4-chlorophenyl)propane-1,2-diamine (S17), yellow solid. ${ }^{1} \mathrm{H}$ NMR (800 MHz, Chloroform- $d$ ), $\delta$ (ppm) 7.35-7.29 (m, 4H), 7.26-7.24 (m, 1H), 7.11-7.08 (m, 2H), 6.53$6.49(\mathrm{~m}, 2 \mathrm{H}), 3.87(\mathrm{~d}, J=13.1 \mathrm{~Hz}, 1 \mathrm{H}), 3.74(\mathrm{~d}, J=13.1 \mathrm{~Hz}, 1 \mathrm{H}), 3.14-3.08$ (m, 1H), 3.01$2.96(\mathrm{~m}, 1 \mathrm{H}), 2.92(\mathrm{ddd}, J=12.1,7.0,5.2 \mathrm{~Hz}, 1 \mathrm{H}), 1.18$ (d, $J=6.3 \mathrm{~Hz}, 3 \mathrm{H}) .{ }^{13} \mathrm{C}$ NMR $(201$ MHz, Chloroform- $d$ ), $\delta$ (ppm) 147.2, 140.4, 129.0, 128.5, 128.0, 127.0, 121.7, 114.0, 51.4, 51.1, 49.3, 18.9. HRMS calcd for $\mathrm{C}_{16} \mathrm{H}_{19} \mathrm{ClN}_{2}[\mathrm{M}+\mathrm{H}]^{+}: 275.1315$; found: 275.1319 .

\section{4-(2-(2-(2-(2-hydroxyethoxy)ethoxy)ethoxy)ethoxy)-N-methyl-N-(1-(4-(1-methyl-1H-}

pyrazol-5-yl)phthalazin-1-yl)piperidin-4-yl)-2-(trifluoromethyl)benzamide

(S19),

colorless oil. ${ }^{1} \mathrm{H}$ NMR (500 MHz, Chloroform- $d$ ), $\delta(\mathrm{ppm})$ major rotamer, $\delta(\mathrm{ppm})$ 8.14-8.03 (m, 2H), 7.91-7.82 (m, 2H), $7.66(\mathrm{~d}, J=2.0 \mathrm{~Hz}, 1 \mathrm{H}), 7.39-7.25(\mathrm{~m}, 2 \mathrm{H}), 7.17(\mathrm{~d}, J=1.5 \mathrm{~Hz}$, $1 \mathrm{H}), 6.60(\mathrm{~d}, J=2.0 \mathrm{~Hz}, 1 \mathrm{H}), 4.94-4.90(\mathrm{~m}, 1 \mathrm{H}), 4.24-4.20(\mathrm{~m}, 4 \mathrm{H}), 4.06(\mathrm{~s}, 3 \mathrm{H}), 3.91-3.88$ (m, 2H), 3.75-3.67 (m, 12H), $3.61(\mathrm{~d}, J=4.0 \mathrm{~Hz}, 2 \mathrm{H}), 3.39-3.37$ (m, 2H,), 2.77 (s, 3H), 2.26$1.76(\mathrm{~m}, 4 \mathrm{H})$; minor rotamer, $\delta(\mathrm{ppm}) 8.14-8.03(\mathrm{~m}, 2 \mathrm{H}), 7.91-7.82(\mathrm{~m}, 2 \mathrm{H}), 7.64(\mathrm{~d}, J=2.0$ $\mathrm{Hz}, 1 \mathrm{H}), 7.39-7.25(\mathrm{~m}, 2 \mathrm{H}), 7.15(\mathrm{~d}, J=1.5 \mathrm{~Hz}, 1 \mathrm{H}), 6.58(\mathrm{~d}, J=2.0 \mathrm{~Hz}, 1 \mathrm{H}), 4.18-4.11$ (m, $4 \mathrm{H}), 4.02(\mathrm{~s}, 3 \mathrm{H}), 3.91-3.88(\mathrm{~m}, 2 \mathrm{H}), 3.75-3.67(\mathrm{~m}, 12 \mathrm{H}), 3.61(\mathrm{~d}, J=4.0 \mathrm{~Hz}, 2 \mathrm{H}), 3.52-3.49$ (m, 1H), 3.10 (s, 3H), 2.99-2.93 (m, 2H), 2.24-1.76 (m, 4H); ${ }^{13} \mathrm{C}$ NMR (126 MHz, Chloroform- 
d), $\delta(\mathrm{ppm})$ major rotamer, $\delta$ 171.0, 168.8, 159.4, 158.7, 147.2, 138.0, 136.6, 131.9, 131.4, $128.4,127.7,127.4(\mathrm{q}, J=31.4 \mathrm{~Hz}), 126.0,124.8(\mathrm{q}, J=2.5 \mathrm{~Hz}), 124.5,123.6(\mathrm{q}, J=272.2$ $\mathrm{Hz}), 121.2,118.0,112.8$ (q, $J=4.5 \mathrm{~Hz}$ ), 108.9, 72.4, 70.6, 70.4, 70.3, 70.0, 69.2, 67.7, 61.4, 56.7, 51.0, 50.7, 38.0, 31.6, 28.5, 27.9, 27.4, 20.9; minor rotamer, $\delta$ (ppm) 171.0, 168.7, 159.3, 158.8, 147.5, 138.0, 136.5, 132.0, 131.5, 128.0, 127.4, 127.4 (q, $J=31.4$ Hz), 126.0, 124.3, $124.0(\mathrm{q}, J=2.1 \mathrm{~Hz}), 123.6(\mathrm{q}, J=272.2 \mathrm{~Hz}), 121.2,117.9,113.0(\mathrm{q}, J=4.5 \mathrm{~Hz}), 109.0,72.4$, 70.6, 70.4, 70.3, 70.0, 69.2, 67.7, 60.2, 53.3, 50.9, 50.2, 49.9, 38.0, 29.5, 29.0, 14.0; HRMS calcd for $\mathrm{C}_{34} \mathrm{H}_{41} \mathrm{~F}_{3} \mathrm{~N}_{6} \mathrm{O}_{6}[\mathrm{M}+\mathrm{H}]^{+}$: 687.3112; found: 687.3135 .

\section{4-(2-(2-(2-(2-azidoethoxy)ethoxy)ethoxy)ethoxy)-N-methyl-N-(1-(4-(1-methyl-1H-}

pyrazol-5-yl)phthalazin-1-yl)piperidin-4-yl)-2-(trifluoromethyl)benzamide

(S20),

colorless oil. ${ }^{1} \mathrm{H}$ NMR (500 MHz, Chloroform- $d$ ), $\delta(\mathrm{ppm})$ major rotamer, $\delta(\mathrm{ppm})$ 8.12-8.04 $(\mathrm{m}, 2 \mathrm{H}), 7.89-7.80(\mathrm{~m}, 2 \mathrm{H}), 7.66(\mathrm{~d}, J=2.0 \mathrm{~Hz}, 1 \mathrm{H}), 7.27-7.24(\mathrm{~m}, 2 \mathrm{H}), 7.14(\mathrm{~d}, J=1.5 \mathrm{~Hz}$, $1 \mathrm{H}), 6.59(\mathrm{~d}, J=2.0 \mathrm{~Hz}, 1 \mathrm{H}), 4.96-4.90(\mathrm{~m}, 1 \mathrm{H}), 4.22-4.19(\mathrm{~m}, 4 \mathrm{H}), 4.06(\mathrm{~s}, 3 \mathrm{H}), 3.91-3.88$ $(\mathrm{m}, 2 \mathrm{H}), 3.74-3.66(\mathrm{~m}, 10 \mathrm{H}), 3.40-3.38(\mathrm{~m}, 4 \mathrm{H}), 2.75(\mathrm{~s}, 3 \mathrm{H}), 2.27-1.74(\mathrm{~m}, 4 \mathrm{H}), 1.66-1.63(\mathrm{~m}$, $2 \mathrm{H})$; minor rotamer, $\delta(\mathrm{ppm}) 8.12-8.04(\mathrm{~m}, 2 \mathrm{H}), 7.89-7.88(\mathrm{~m}, 2 \mathrm{H}), 7.65(\mathrm{~d}, J=2.0 \mathrm{~Hz}, 1 \mathrm{H})$, 7.27-7.24 (m, 2H), 7.13 (d, $J=1.5 \mathrm{~Hz}, 1 \mathrm{H}), 6.58$ (d, $J=2.0 \mathrm{~Hz}, 1 \mathrm{H}), 4.22-4.19(\mathrm{~m}, 4 \mathrm{H}), 4.02$ $(\mathrm{s}, 3 \mathrm{H}), 3.91-3.88(\mathrm{~m}, 2 \mathrm{H}), 3.74-3.66(\mathrm{~m}, 10 \mathrm{H}), 3.54-3.47(\mathrm{~m}, 1 \mathrm{H}), 3.10(\mathrm{~s}, 3 \mathrm{H}), 2.98-2.91(\mathrm{~m}$, $2 \mathrm{H}), 2.24-1.76(\mathrm{~m}, 4 \mathrm{H}), 1.66-1.63(\mathrm{~m}, 2 \mathrm{H}) ;{ }^{13} \mathrm{C} \mathrm{NMR}$ (126 MHz, Chloroform- $d$ ), $\delta$ (ppm) major rotamer, $\delta 168.6,159.2,158.5,147.0,137.7,136.4,131.7,131.2,129.4,128.3,127.7,127.4$ $(\mathrm{q}, J=31.4 \mathrm{~Hz}), 126.4,125.0(\mathrm{q}, J=2.5 \mathrm{~Hz}), 124.9,123.1(\mathrm{q}, J=272.2 \mathrm{~Hz}), 121.0,117.7$, $112.7(\mathrm{q}, J=4.5 \mathrm{~Hz}), 108.7,70.9,70.4,70.24,70.21$ 70.20, 69.6, 69.0, 67.6, 56.4, 50.8, 50.6, 50.4, 50.2, 49.8, 42.4, 37.8, 31.4, 29.2, 28.8, 28.4, 27.7, 27.2; minor rotamer, $\delta$ (ppm) 168.4, 159.0, 158.7, 147.2, 137.7, 136.3, 131.8, 131.3, 129.2, 128.3, 127.4, 127.4 (q, $J=31.4 \mathrm{~Hz}$ ), $126.3,124.3,124.0$ (q, $J=2.1 \mathrm{~Hz}), 123.1$ (q, $J=272.2 \mathrm{~Hz}), 120.9,117.6,112.9$ (q, $J=4.5 \mathrm{~Hz})$, 109.0, 72.4, 70.6, 70.4, 70.3, 70.0, 69.2, 67.7, 60.2, 53.3, 50.9, 50.2, 49.9, 37.8, 29.5, 29.0, 14.0; HRMS calcd for $\mathrm{C}_{34} \mathrm{H}_{40} \mathrm{~F}_{3} \mathrm{~N}_{9} \mathrm{O}_{5}[\mathrm{M}+\mathrm{H}]^{+}:$: 712.3177; found: 712.3178 .

\section{4-((15-(5,5-difluoro-7,9-dimethyl-5H-4l4,5l4-dipyrrolo[1,2-c:2',1'-f][1,3,2]diazaborinin-}

3-yl)-13-oxo-3,6,9-trioxa-12-azapentadecyl)oxy)-N-methyl-N-(1-(4-(1-methyl-1H-

pyrazol-5-yl)phthalazin-1-yl)piperidin-4-yl)-2-(trifluoromethyl)benzamide (BODIPY-

LY), yellow solid. ${ }^{1} \mathrm{H}$ NMR (600 MHz, Chloroform- $d$ ), $\delta$ (ppm) 8.14-8.13 (m, 1H), 8.09$8.06(\mathrm{~m}, 2 \mathrm{H}), 7.90-7.83(\mathrm{~m}, 3 \mathrm{H}), 7.68-7.67(\mathrm{~m}, 1 \mathrm{H}), 7.24$ (br, 1H), 7.21 (d, J=4 Hz, 1H), 7.12$7.10(\mathrm{~m}, 1 \mathrm{H}), 6.88-6.87(\mathrm{~m}, 1 \mathrm{H}), 6.60-6.58(\mathrm{~m}, 1 \mathrm{H}), 6.33-6.29(\mathrm{~m}, 2 \mathrm{H}), 6.10(\mathrm{~s}, 1 \mathrm{H}), 4.96-4.90$ $(\mathrm{m}, 1 \mathrm{H}), 4.17-4.15(\mathrm{~m}, 4 \mathrm{H}), 4.06-4.02(\mathrm{~m}, 3 \mathrm{H}), 3.86-3.85(\mathrm{~m}, 2 \mathrm{H}), 3.73-3.71(\mathrm{~m}, 2 \mathrm{H}), 3.67-$ $3.58(\mathrm{~m}, 6 \mathrm{H}), 3.54-3.47(\mathrm{~m}, 2 \mathrm{H}), 3.43-3.38(\mathrm{~m}, 3 \mathrm{H}), 3.29-3.27(\mathrm{~m}, 2 \mathrm{H}), 3.10(\mathrm{~s}, 1 \mathrm{H}), 2.74(\mathrm{~s}$, $1 \mathrm{H}), 2.64-2.62(\mathrm{~m}, 2 \mathrm{H}), 2.56-2.55(\mathrm{~m}, 2 \mathrm{H}), 2 . .25-2.20(\mathrm{~m}, 4 \mathrm{H}), 2.01(\mathrm{~s}, 3 \mathrm{H})$. HRMS calcd for $\mathrm{C}_{44} \mathrm{H}_{53} \mathrm{BF}_{5} \mathrm{~N}_{9} \mathrm{O}_{6}[\mathrm{M}+\mathrm{H}]^{+}$: 960.4367 ; found: 960.4368 . 


\section{NMR Spectra}

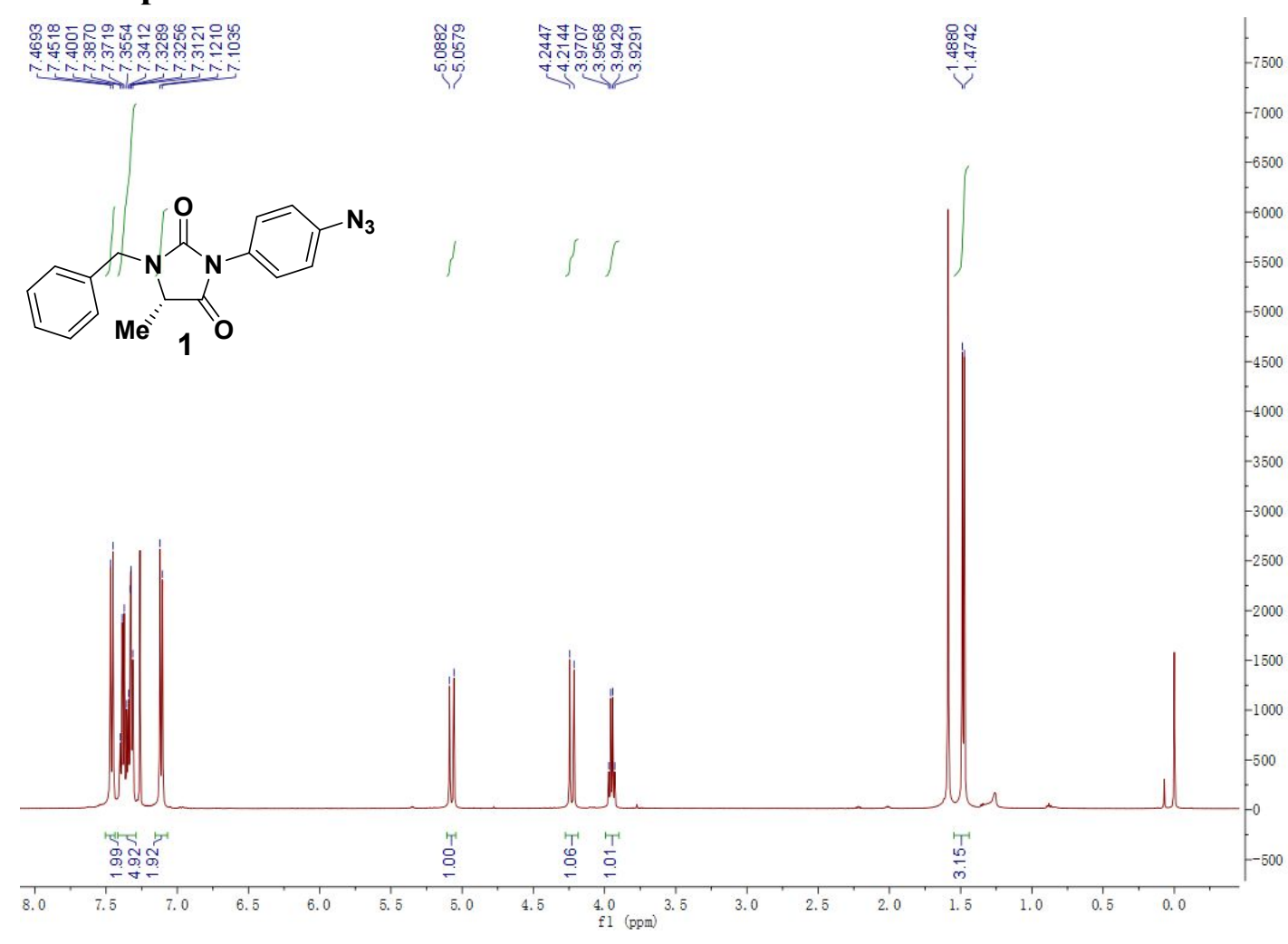

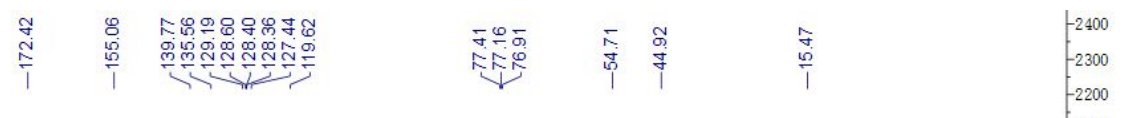

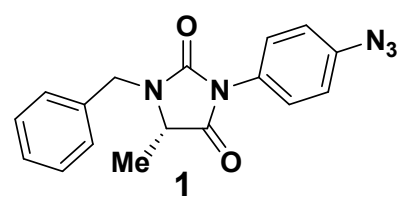




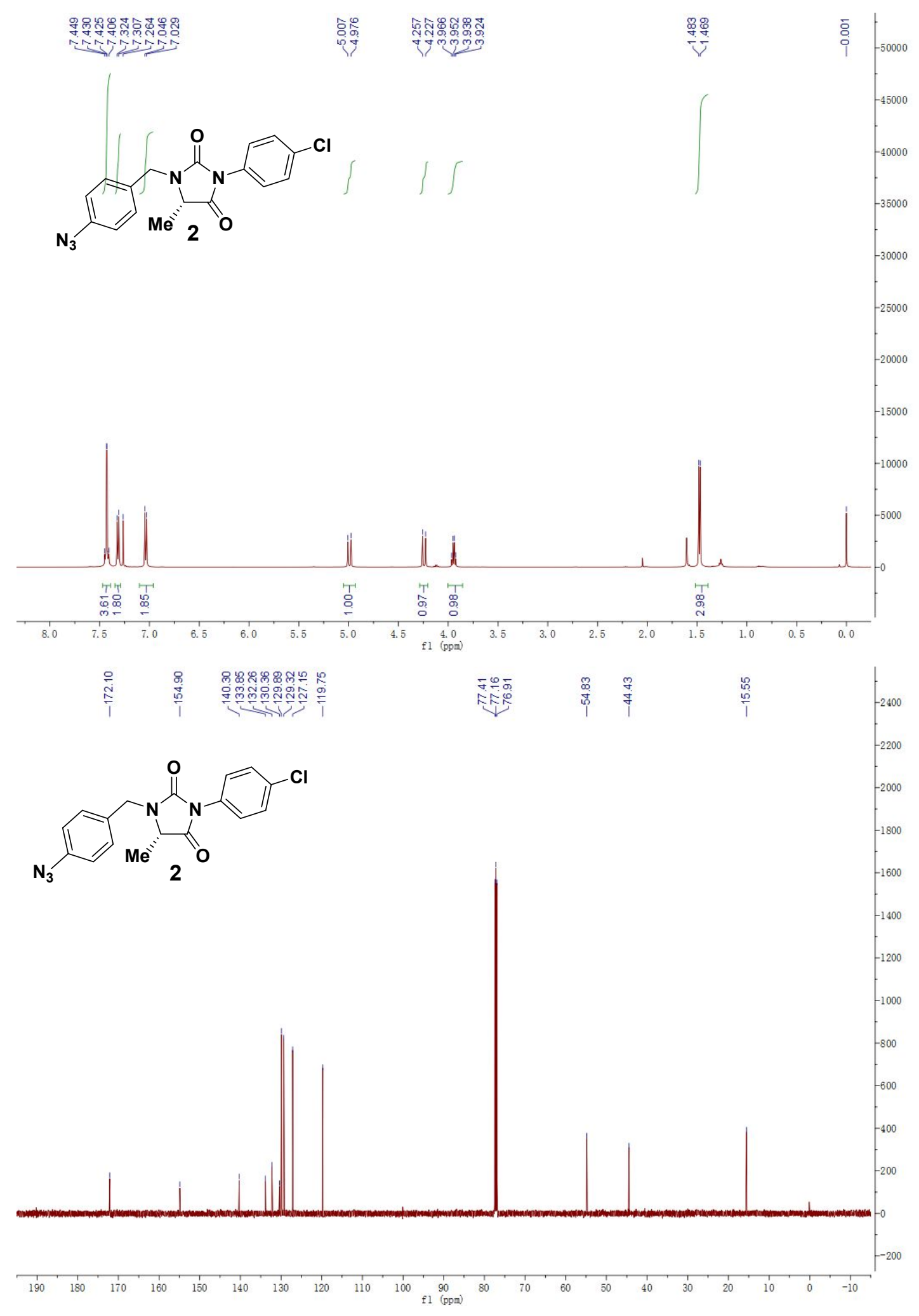




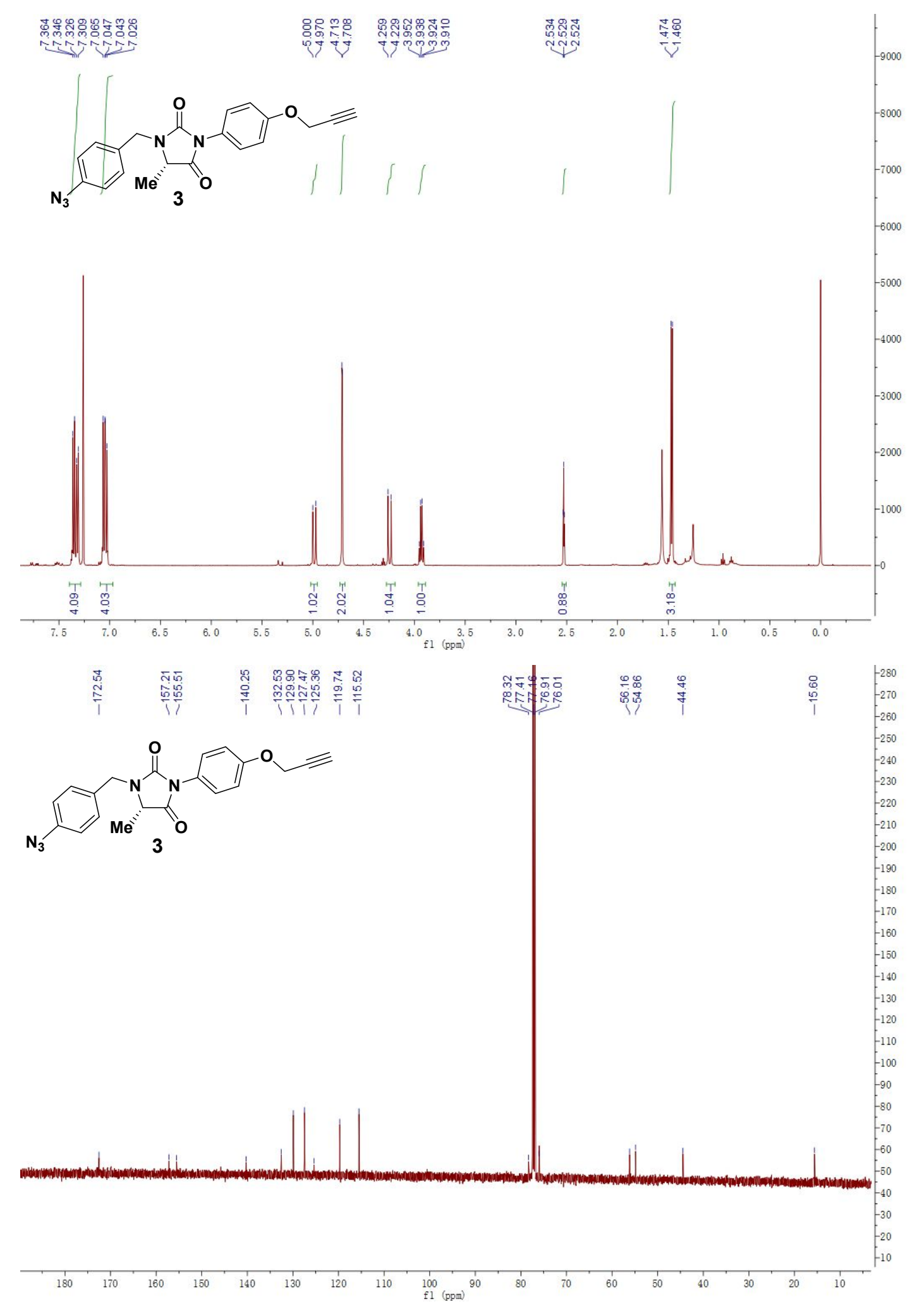



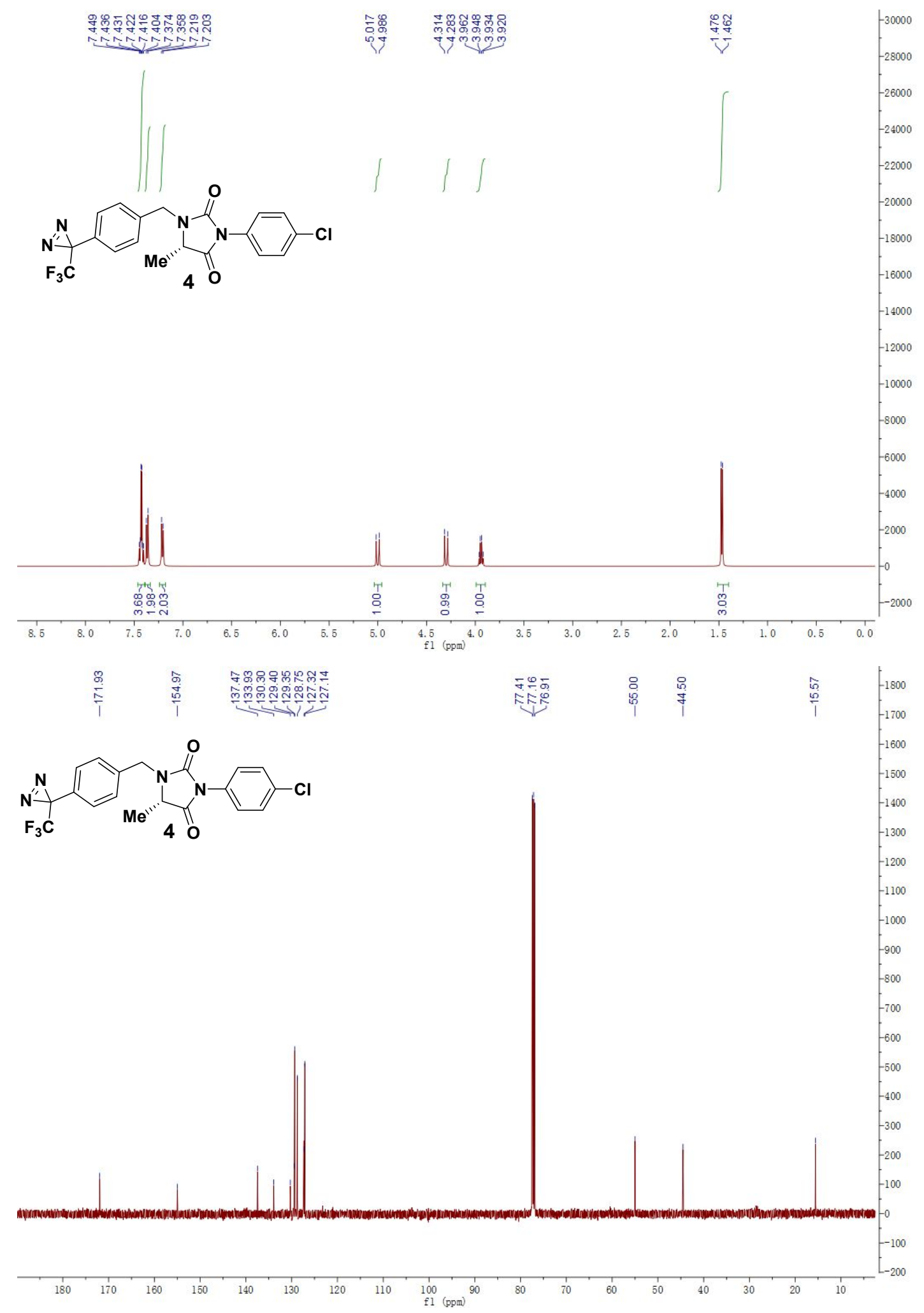

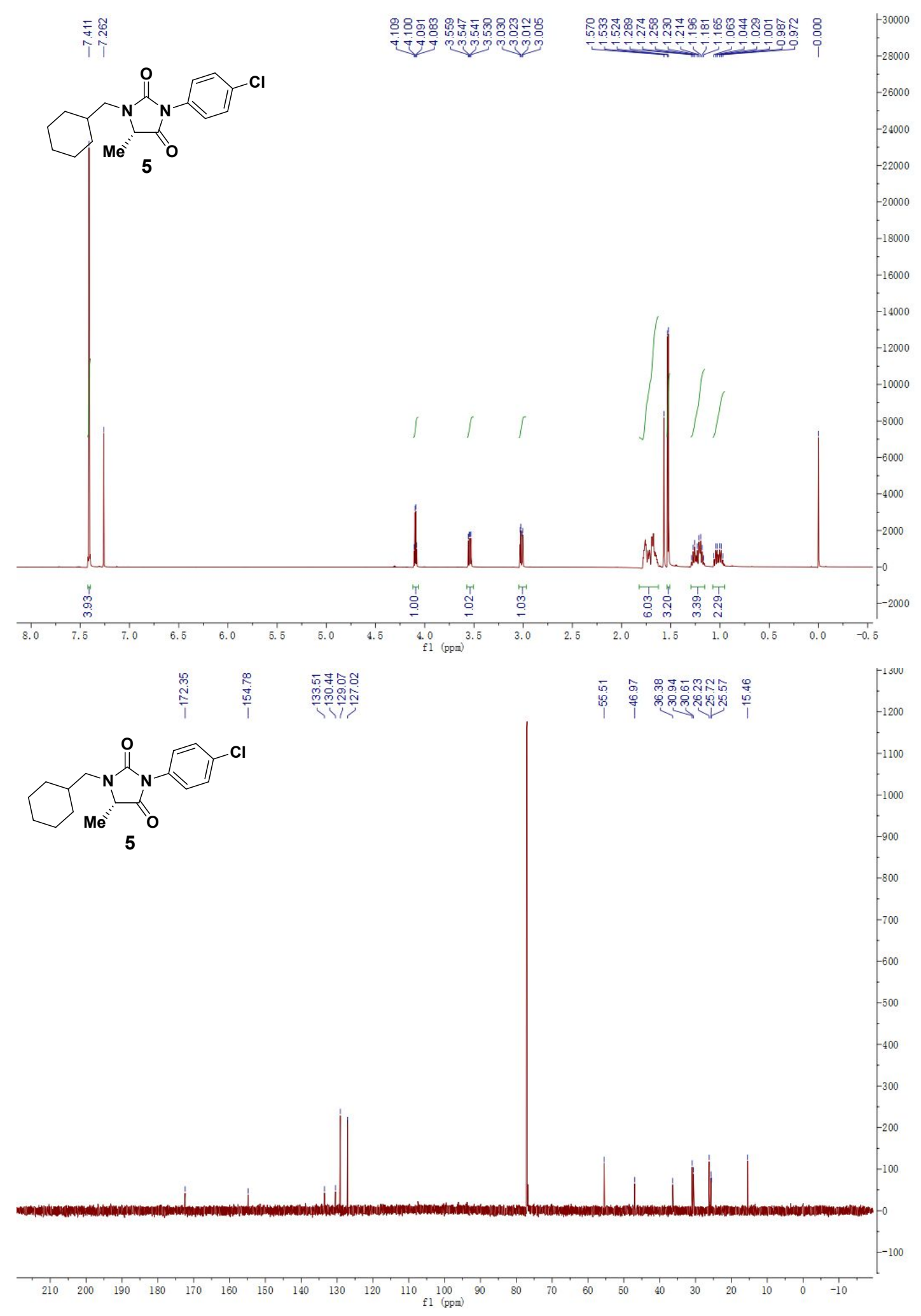


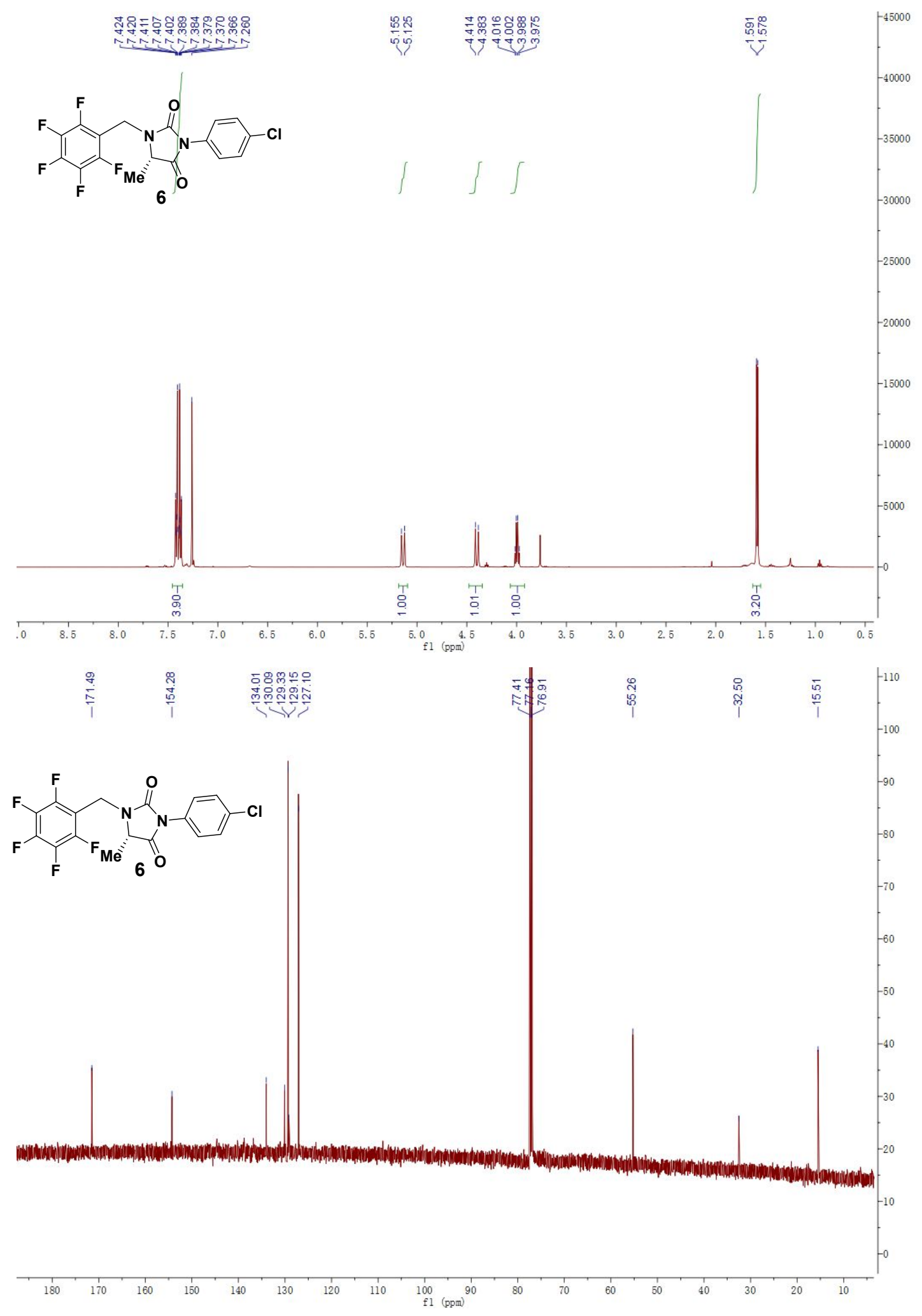



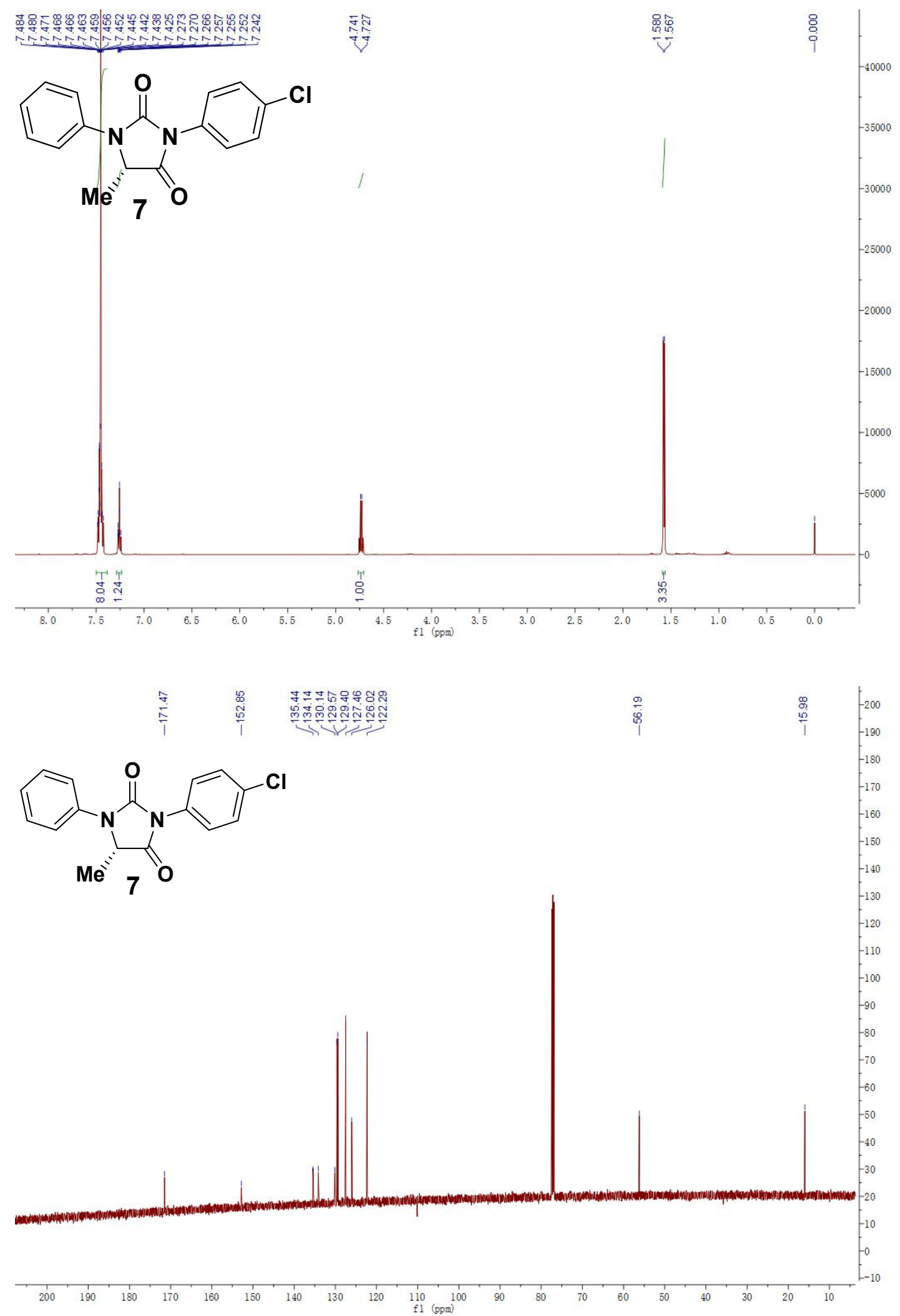


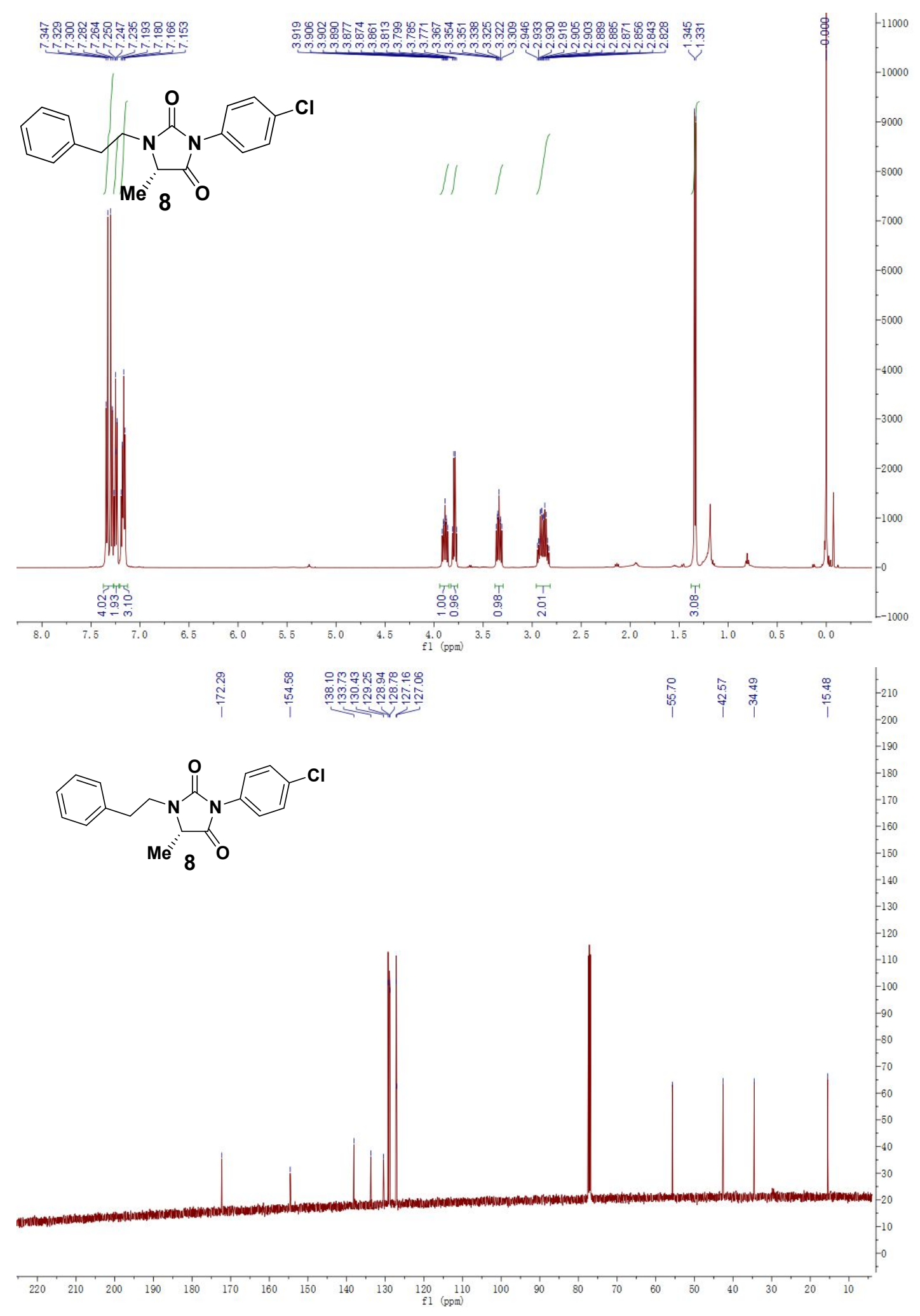



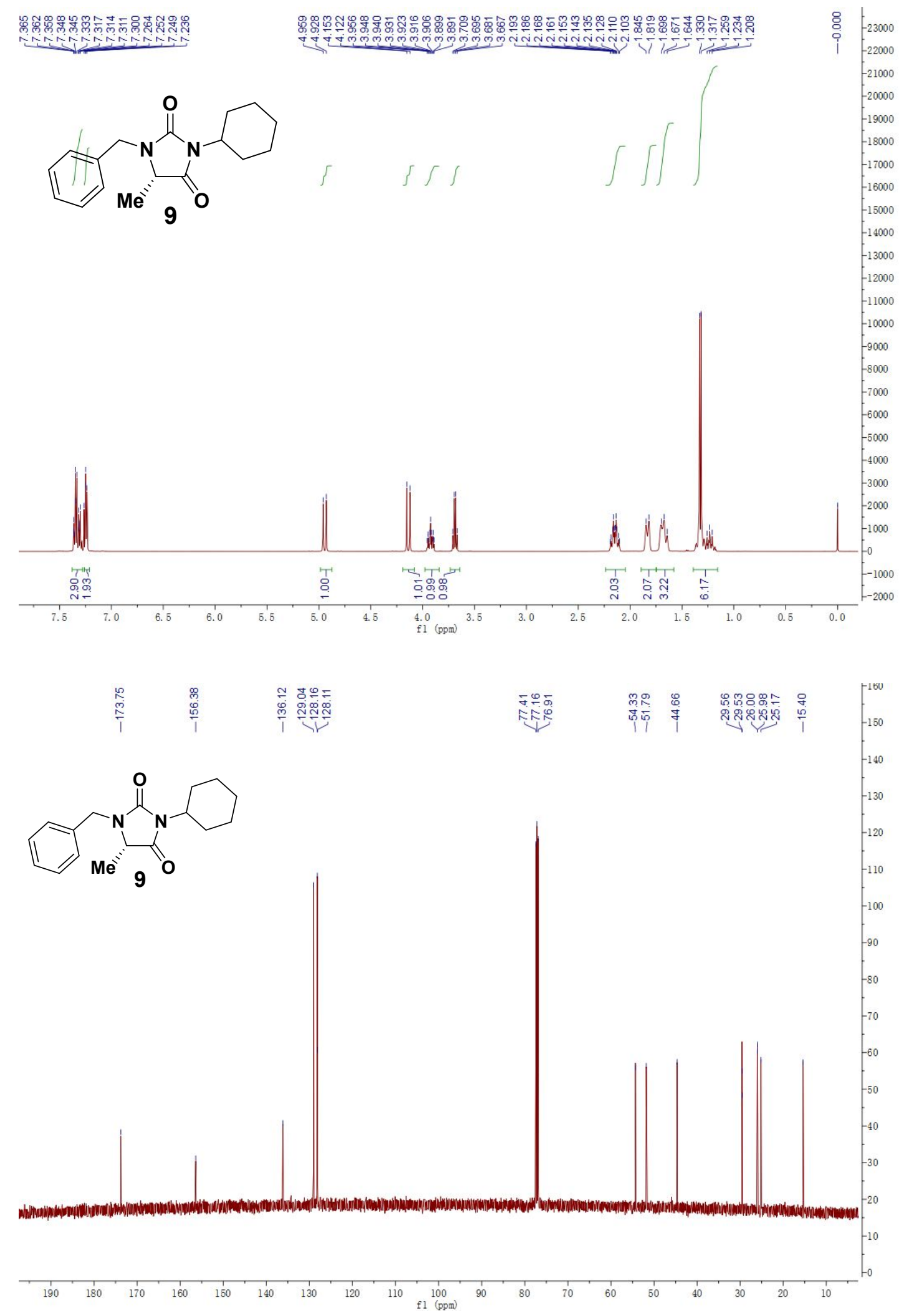

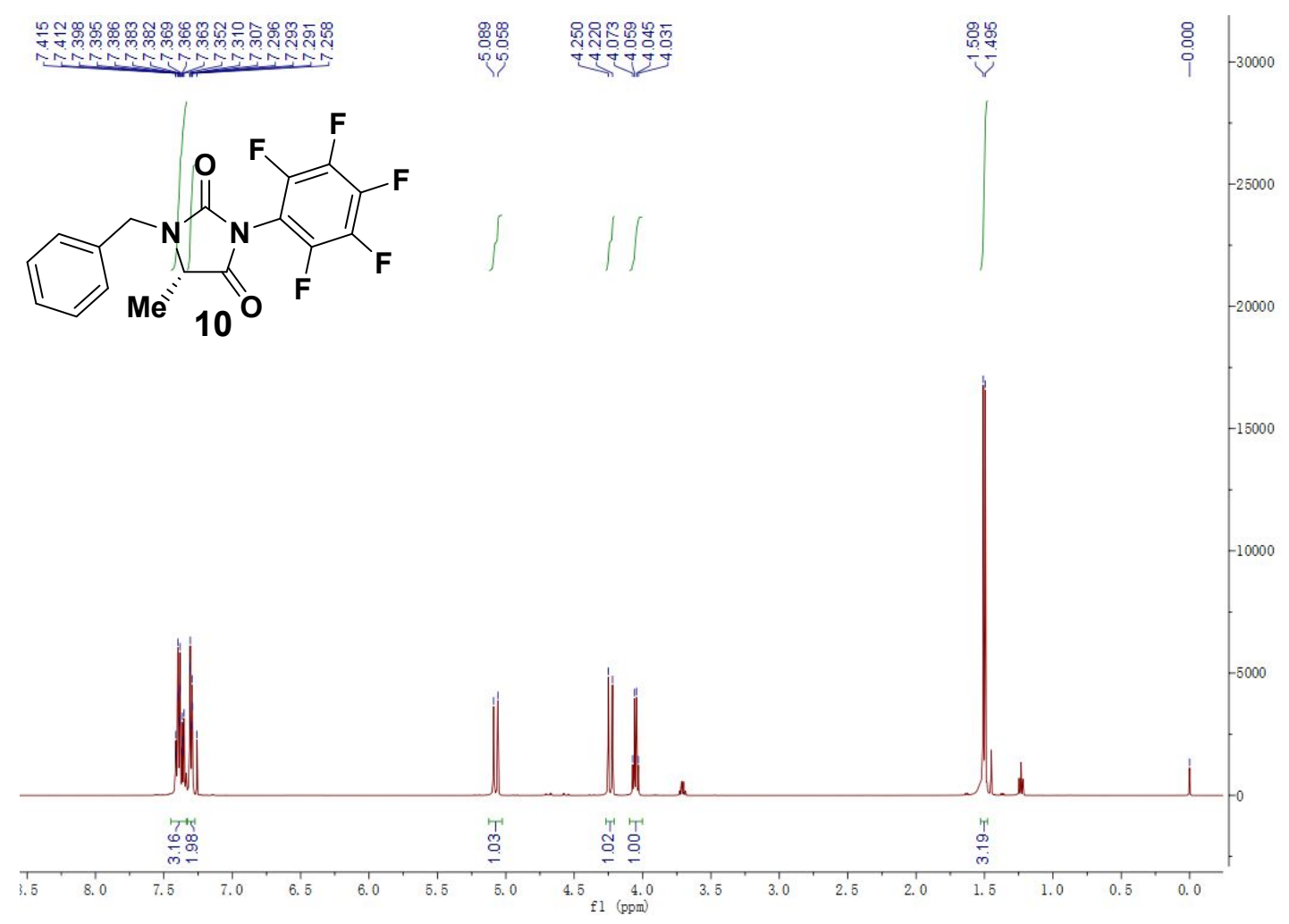

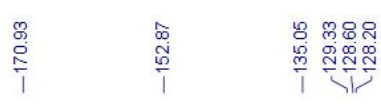

永尔
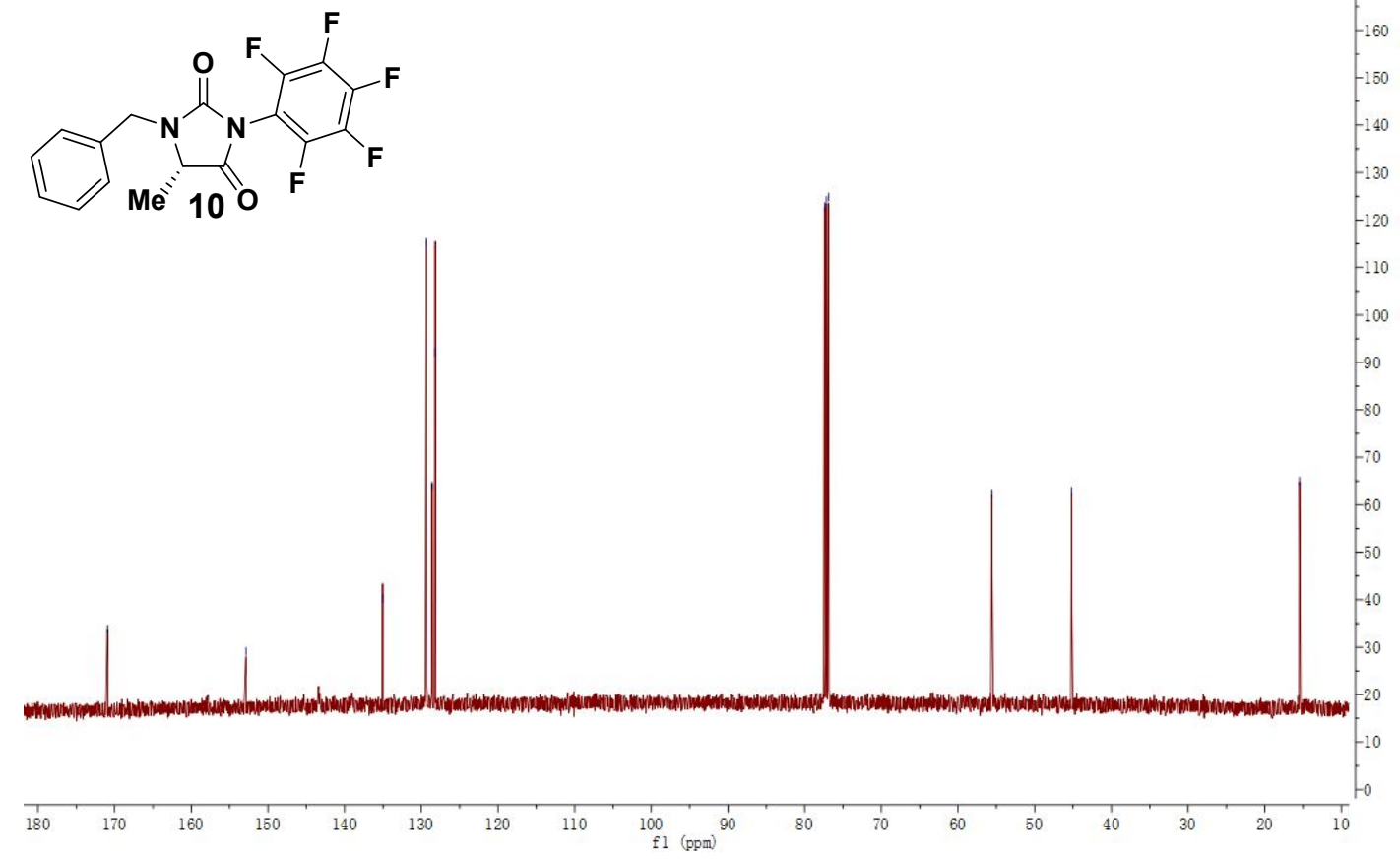


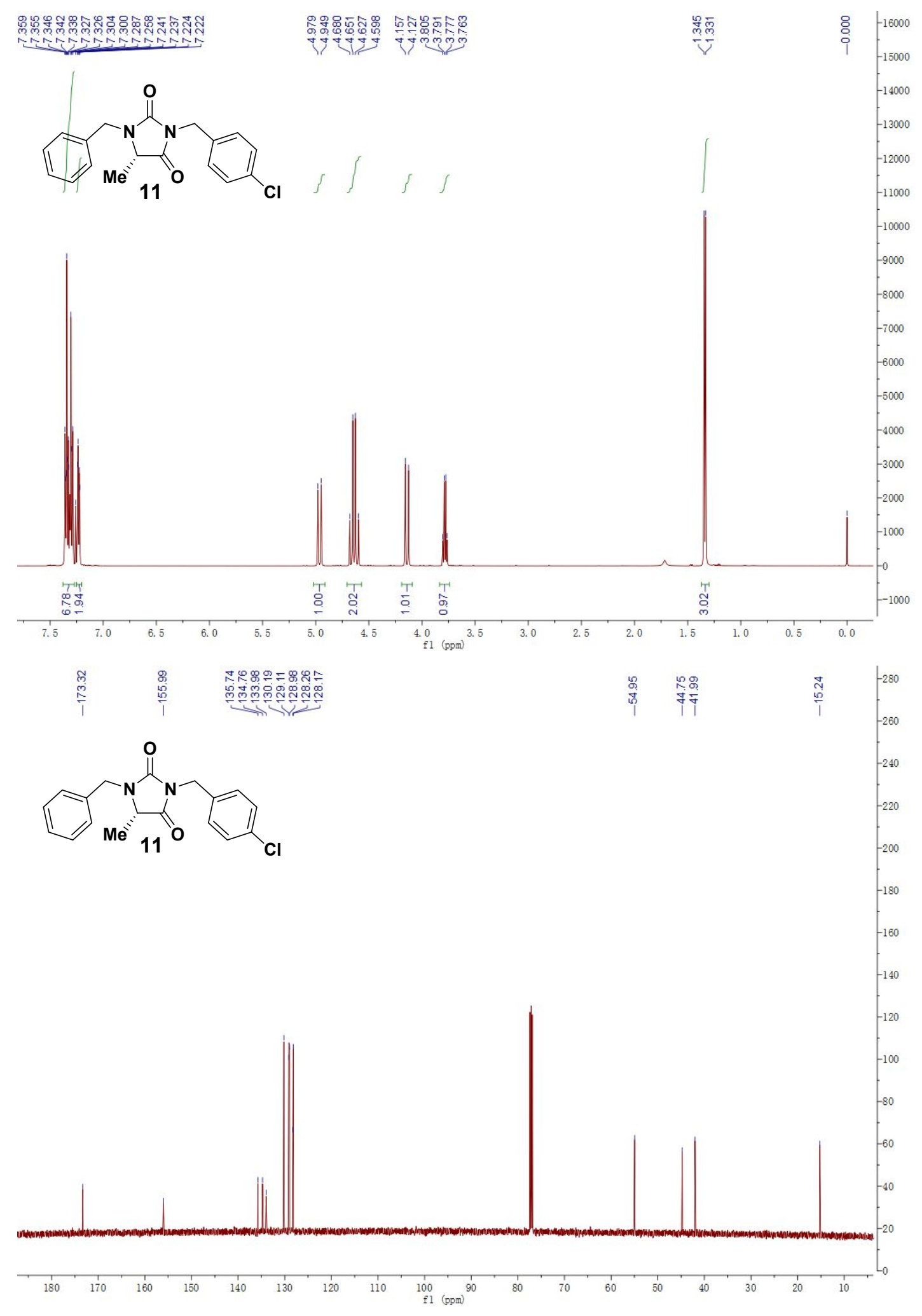



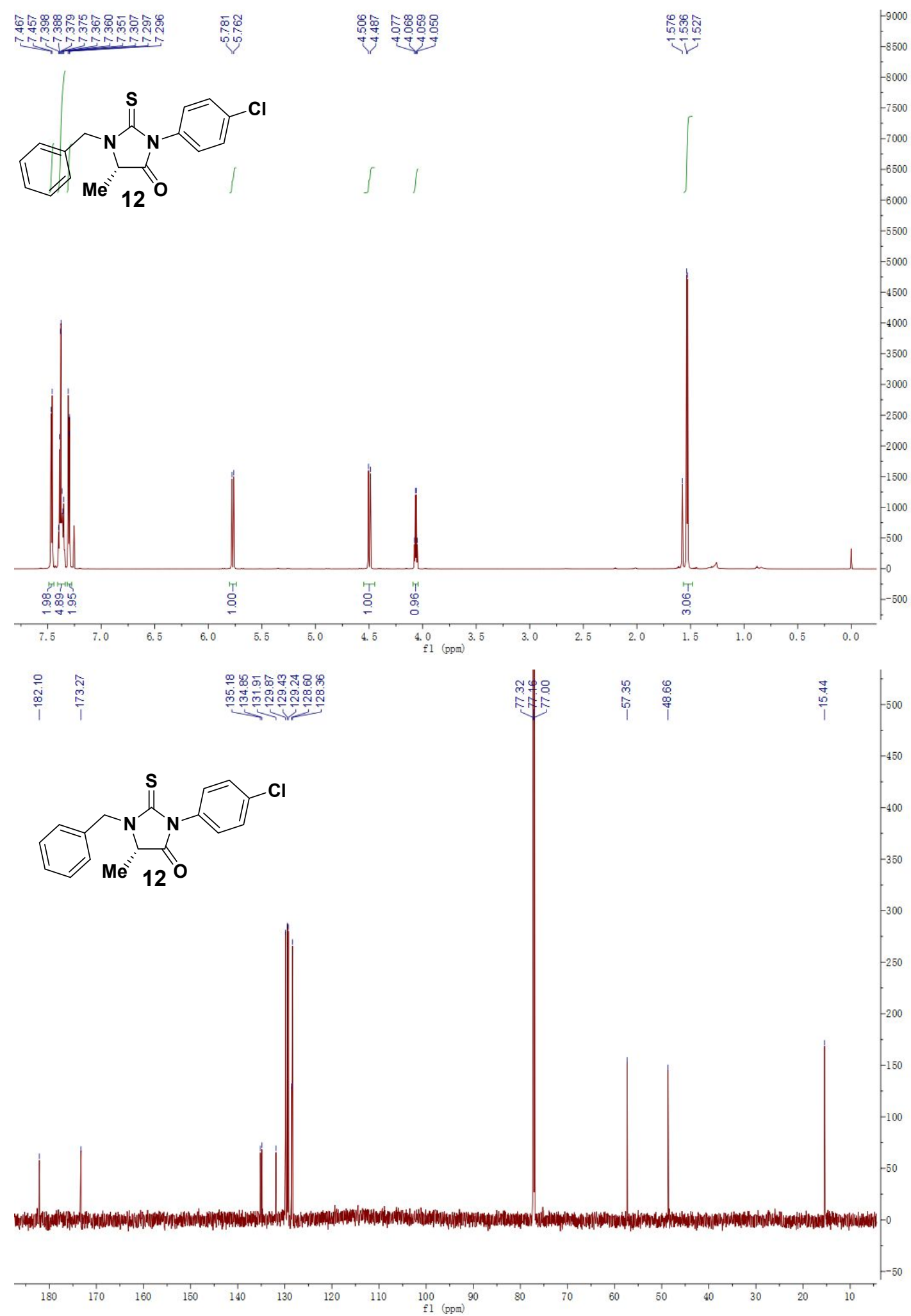

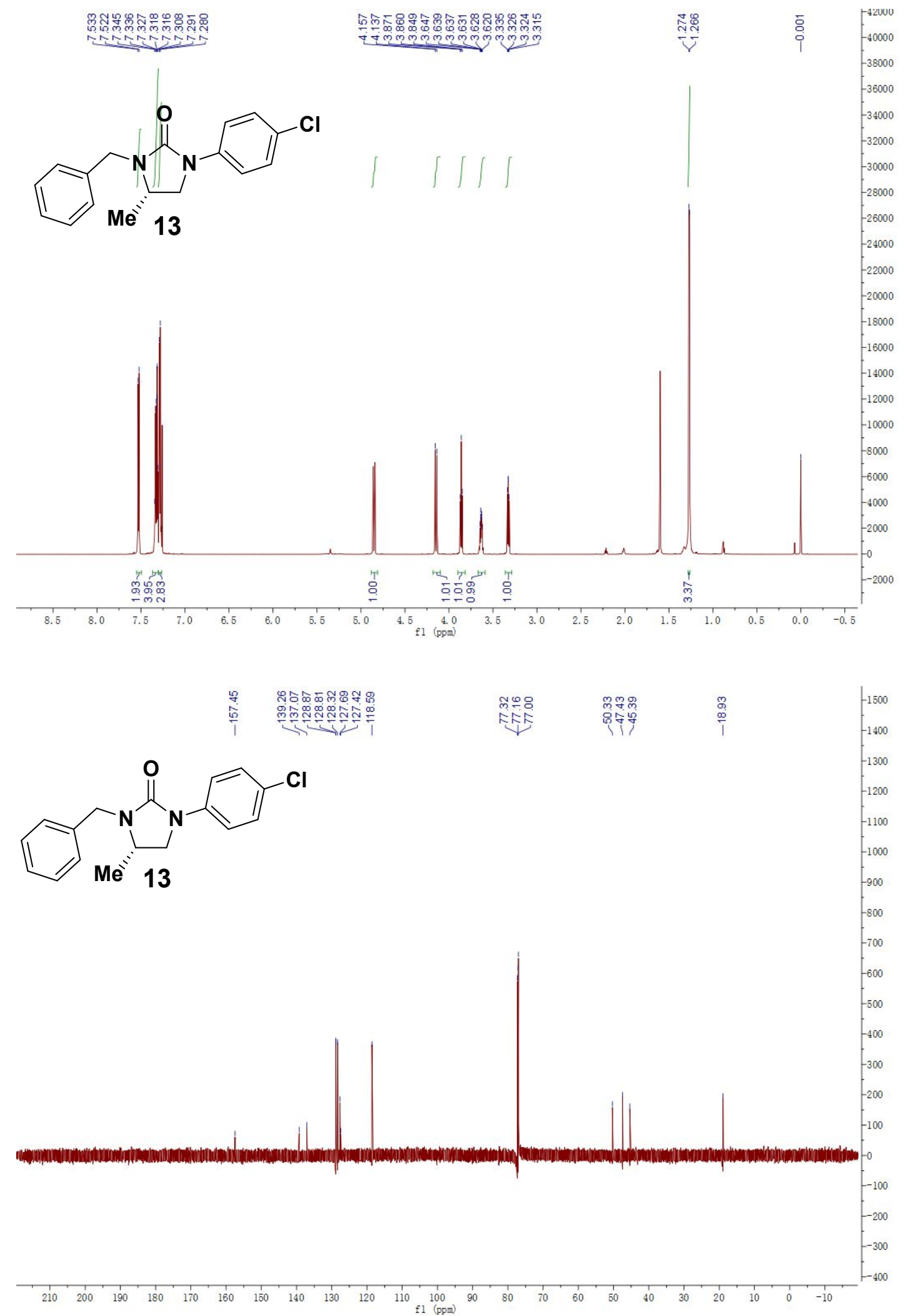


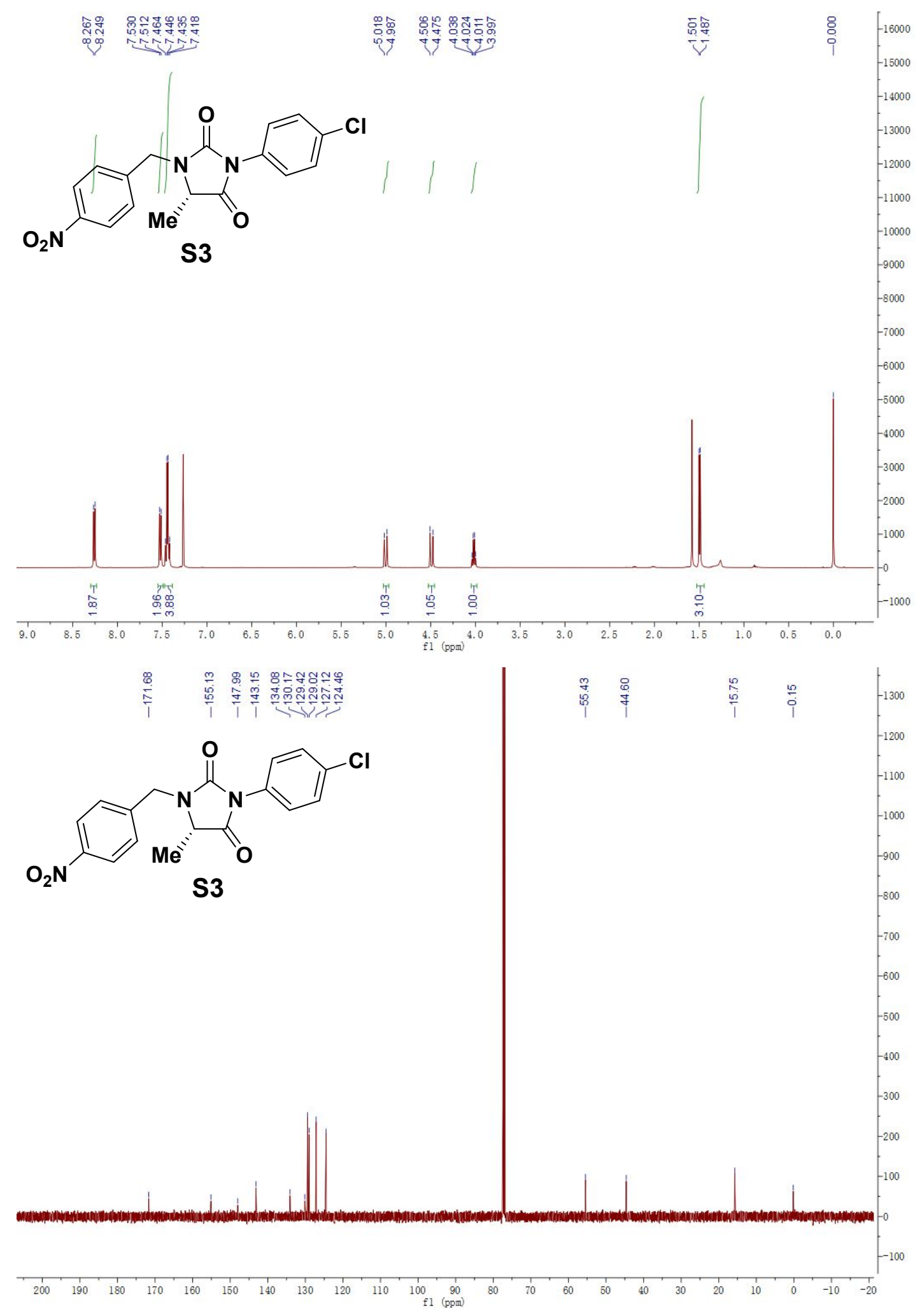




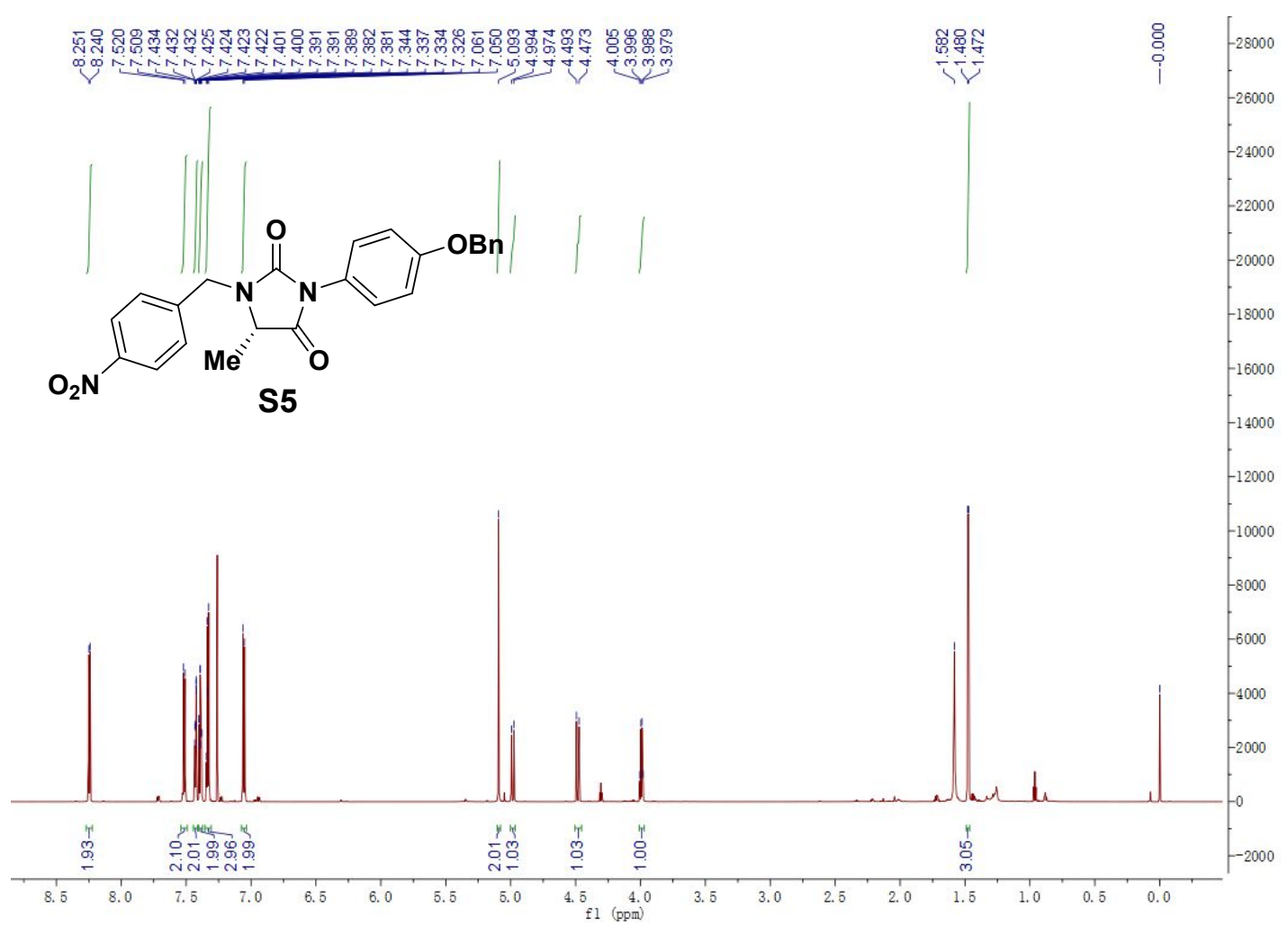

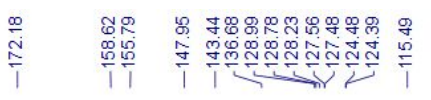

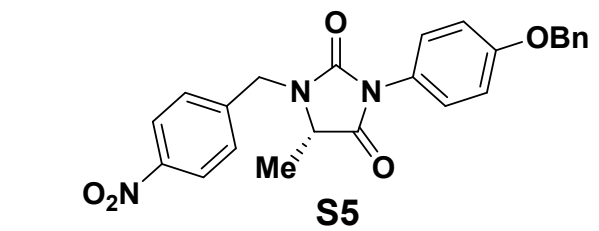

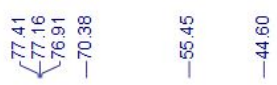

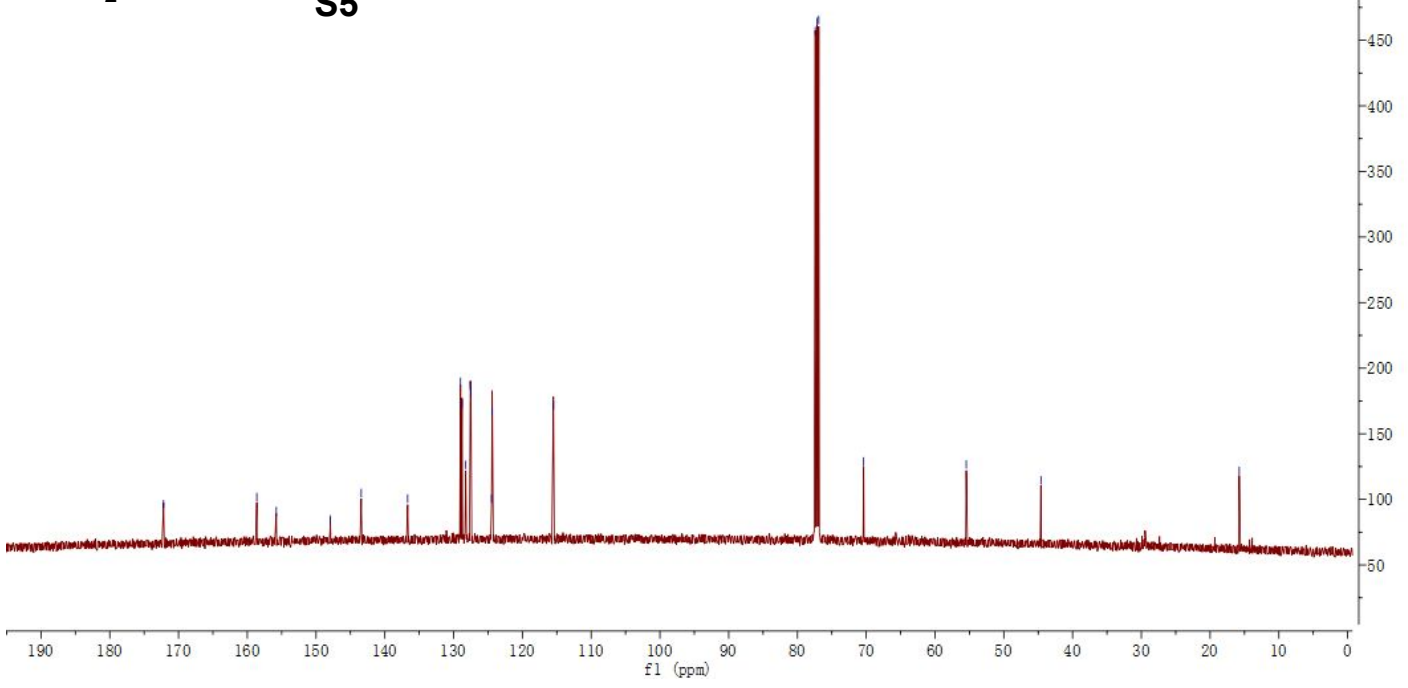



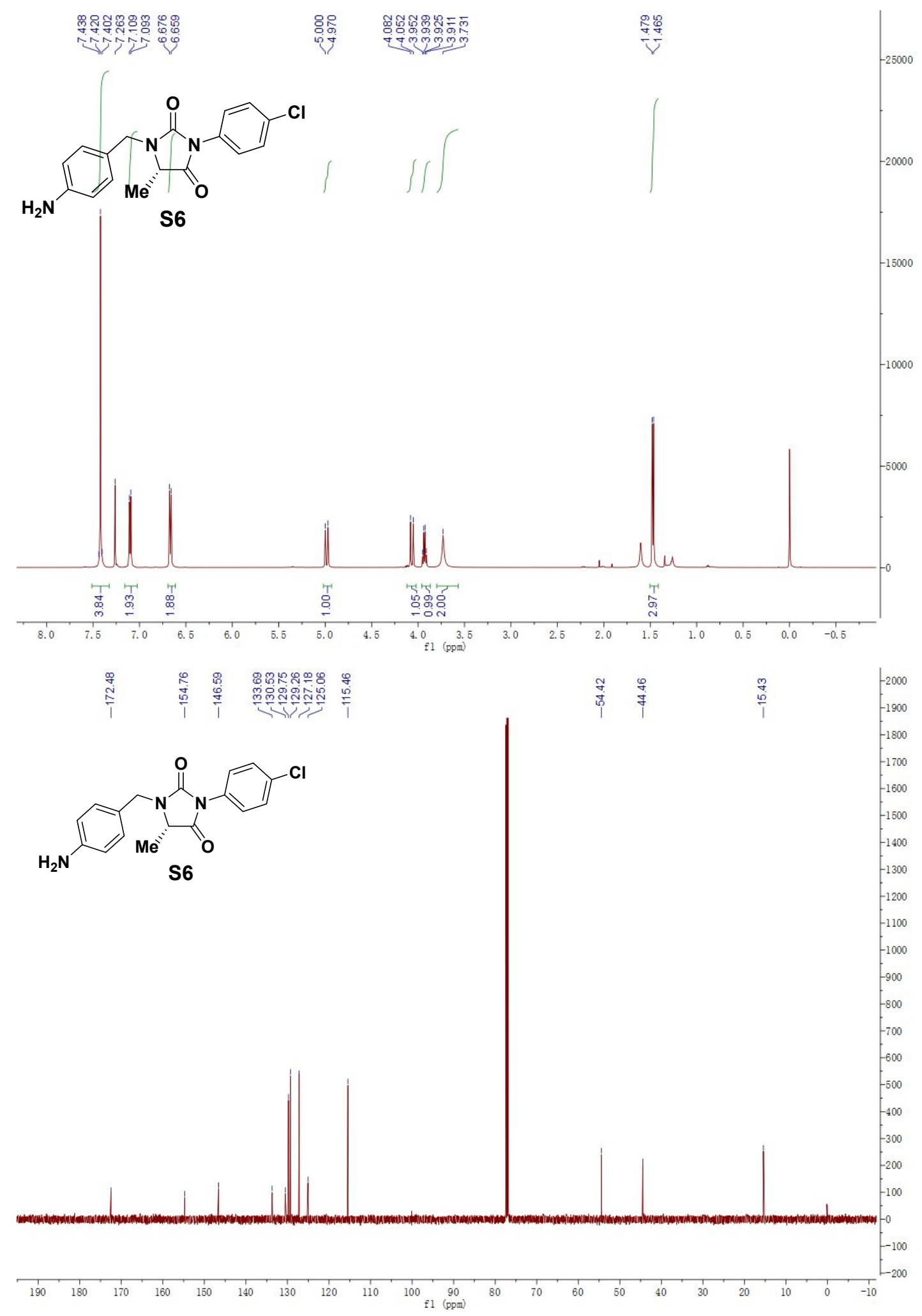


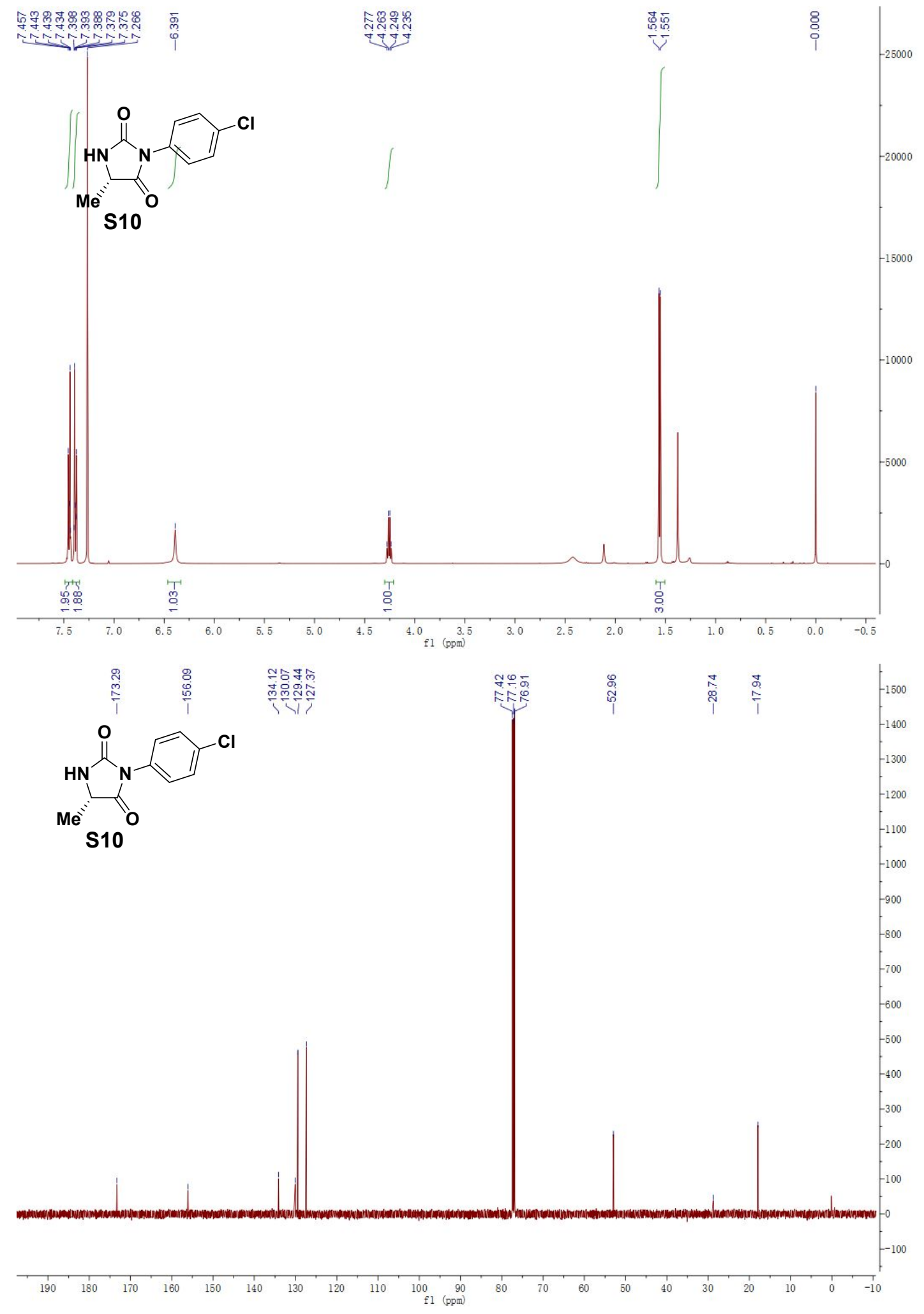



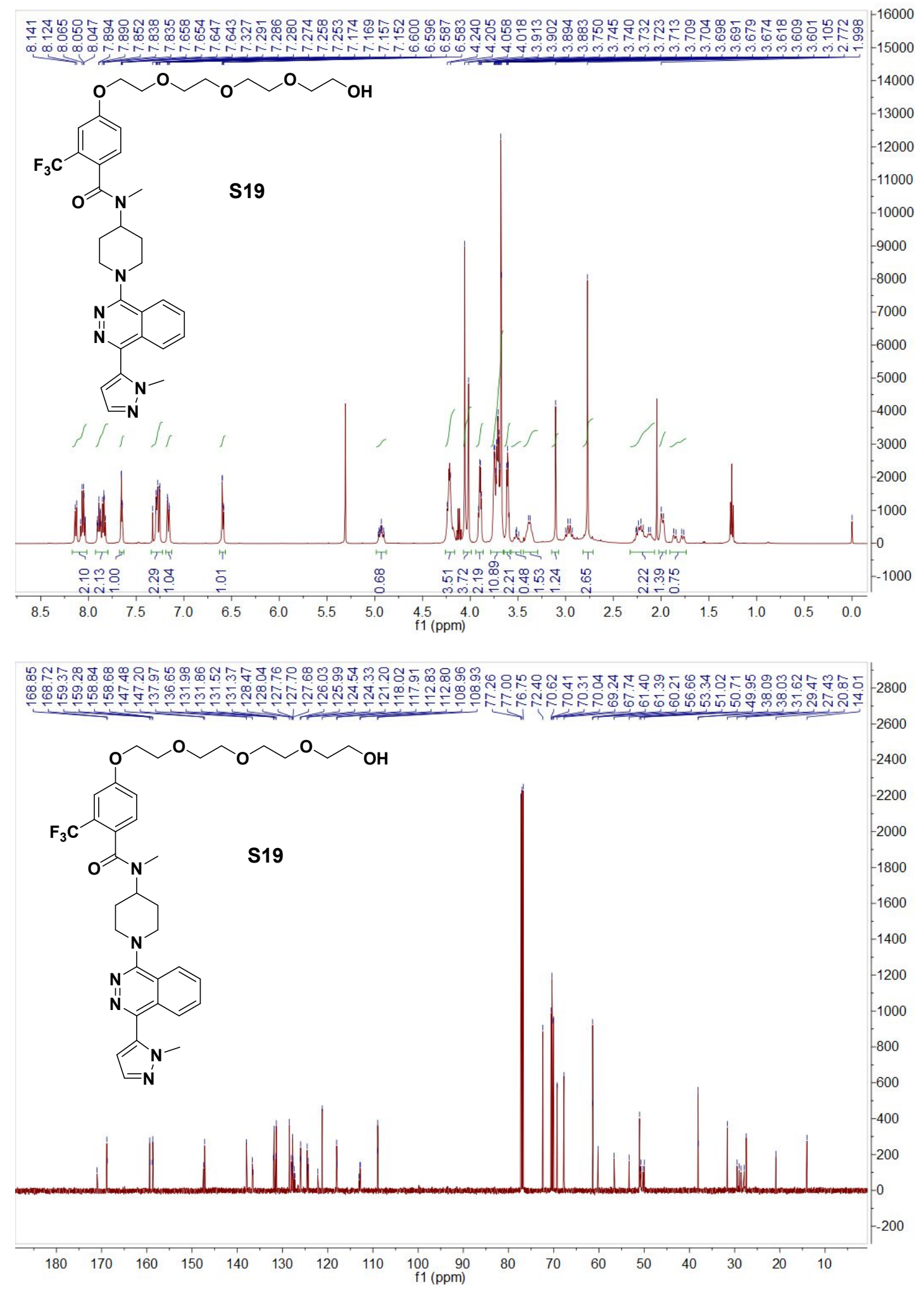

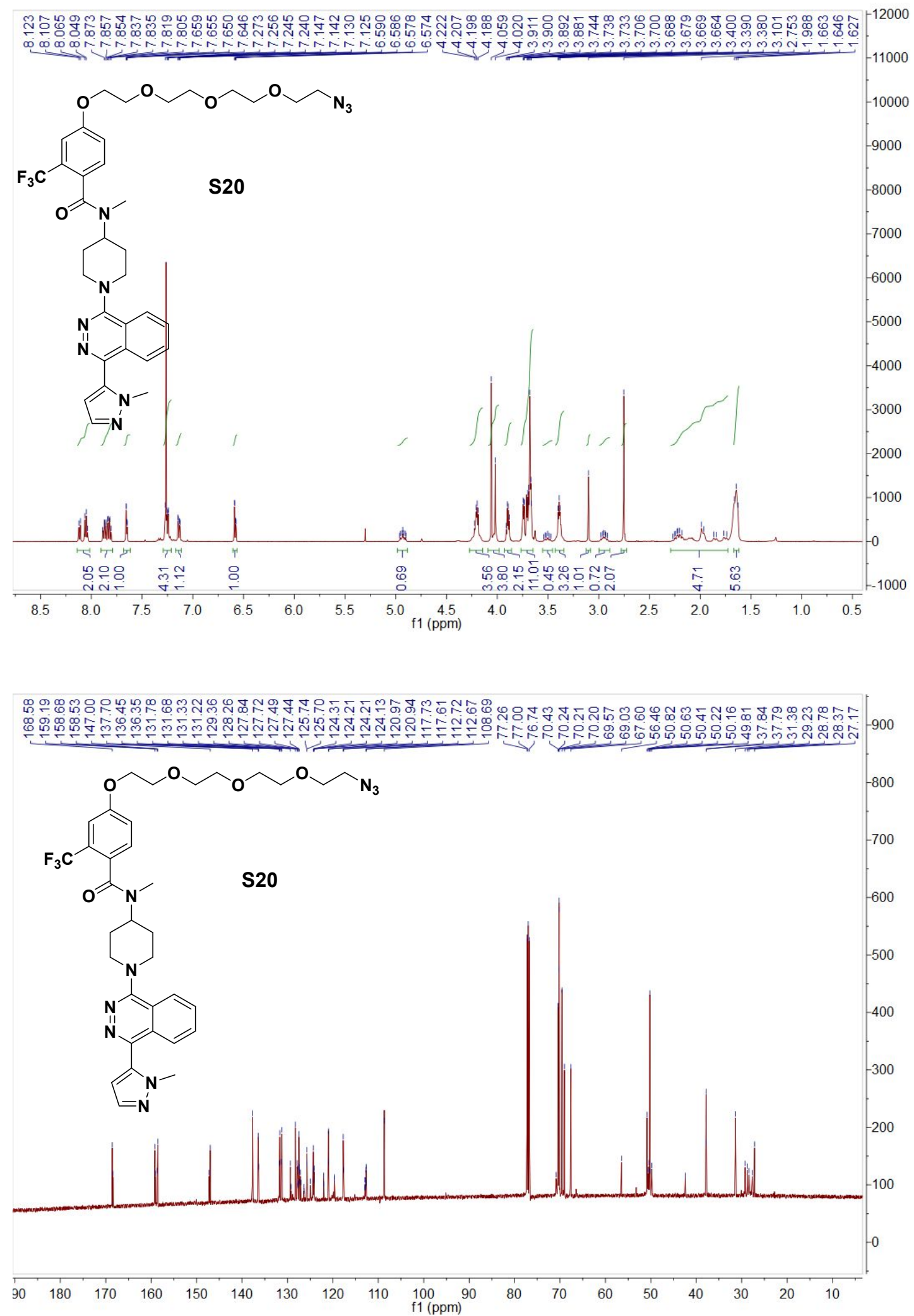


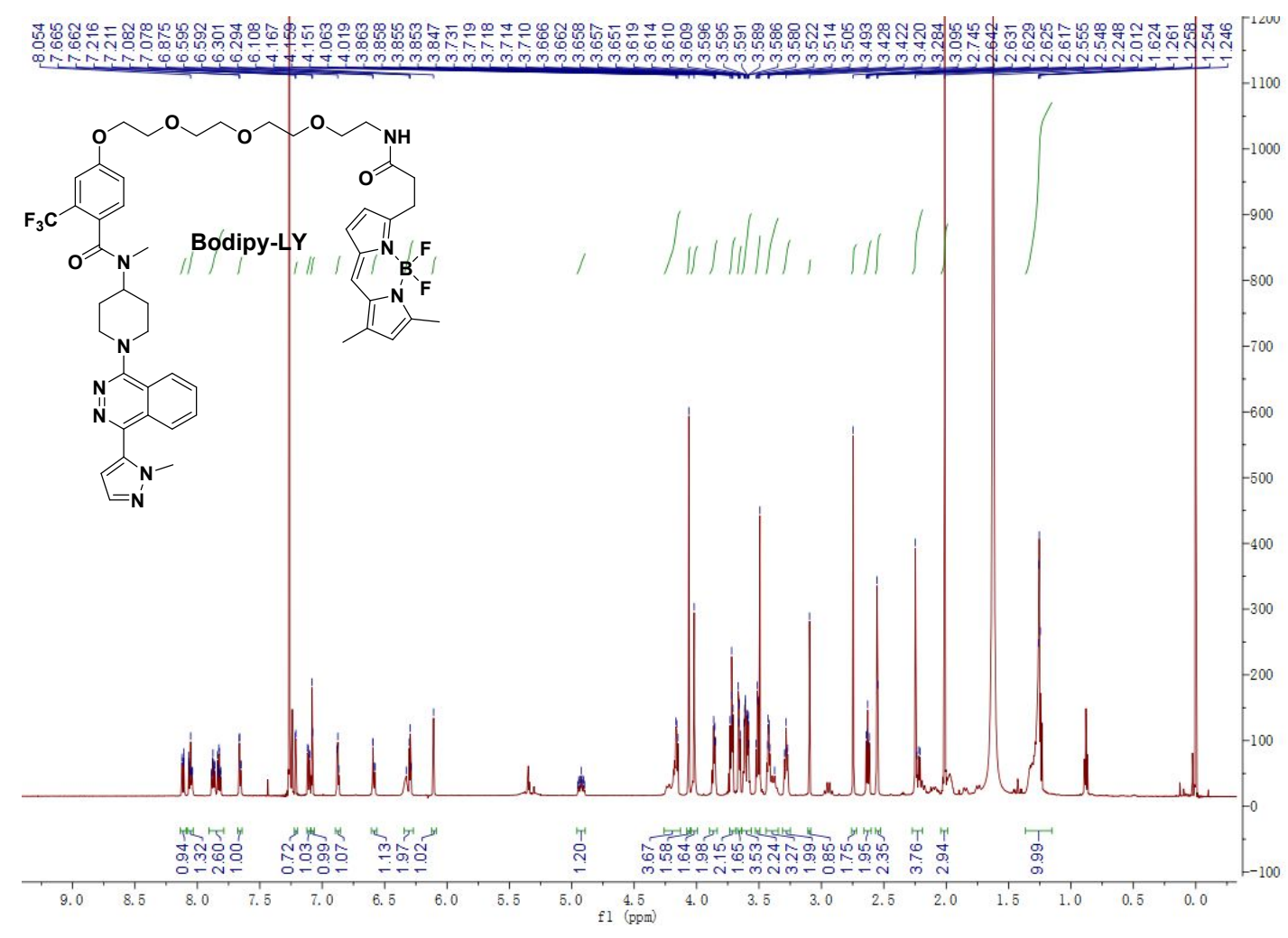




\section{Purity characterization}

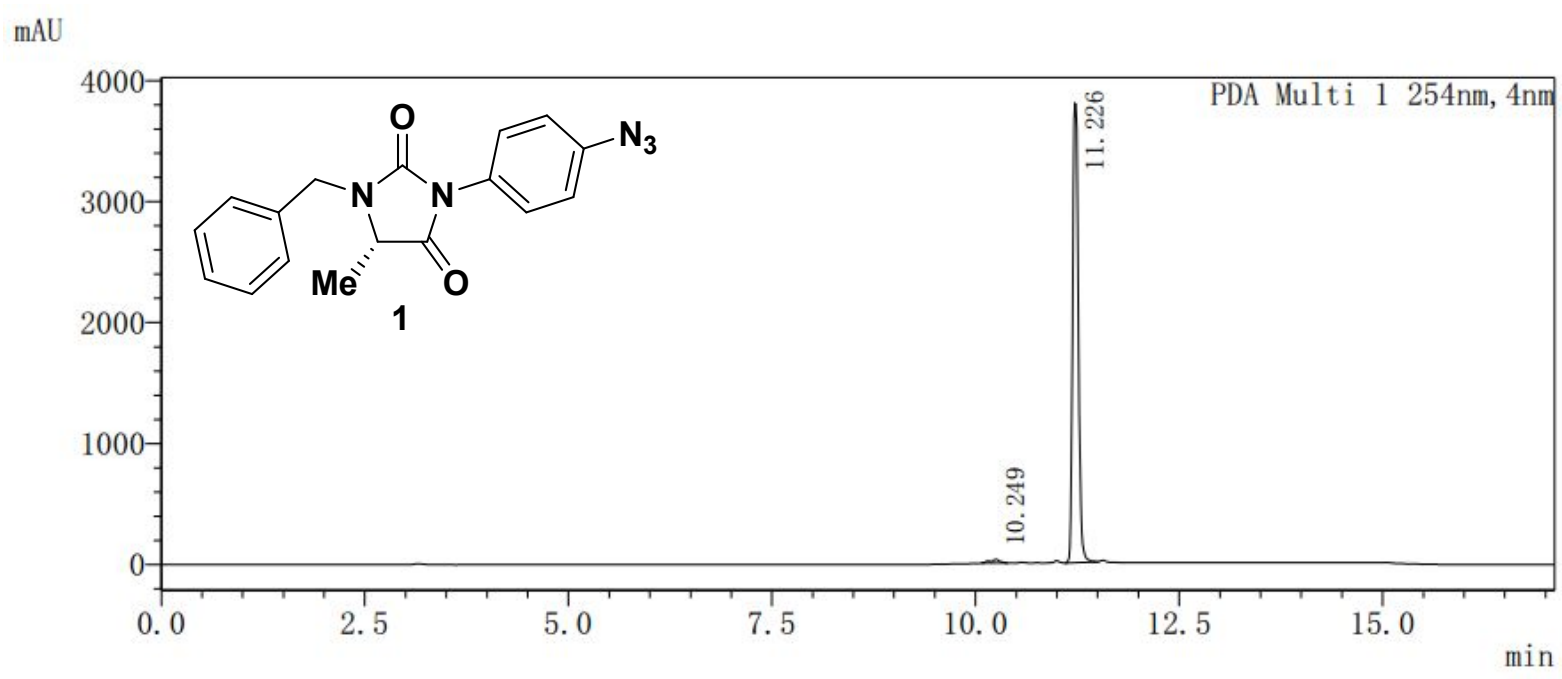

PDA Ch1 254nm

\begin{tabular}{|c|c|c|c|c|c|}
\hline Peak\# & Ret. Time $(\mathrm{min})$ & Height(mAU) & Height $\%$ & Area(mAU*s & Area $\%$ \\
\hline 1 & 10.249 & 28484 & 0.745 & 230836 & 1.223 \\
\hline 2 & 11.226 & 3793439 & 99.255 & 18648782 & 98.777 \\
\hline 总计 & & 3821924 & 100.000 & 18879617 & 100.000 \\
\hline
\end{tabular}

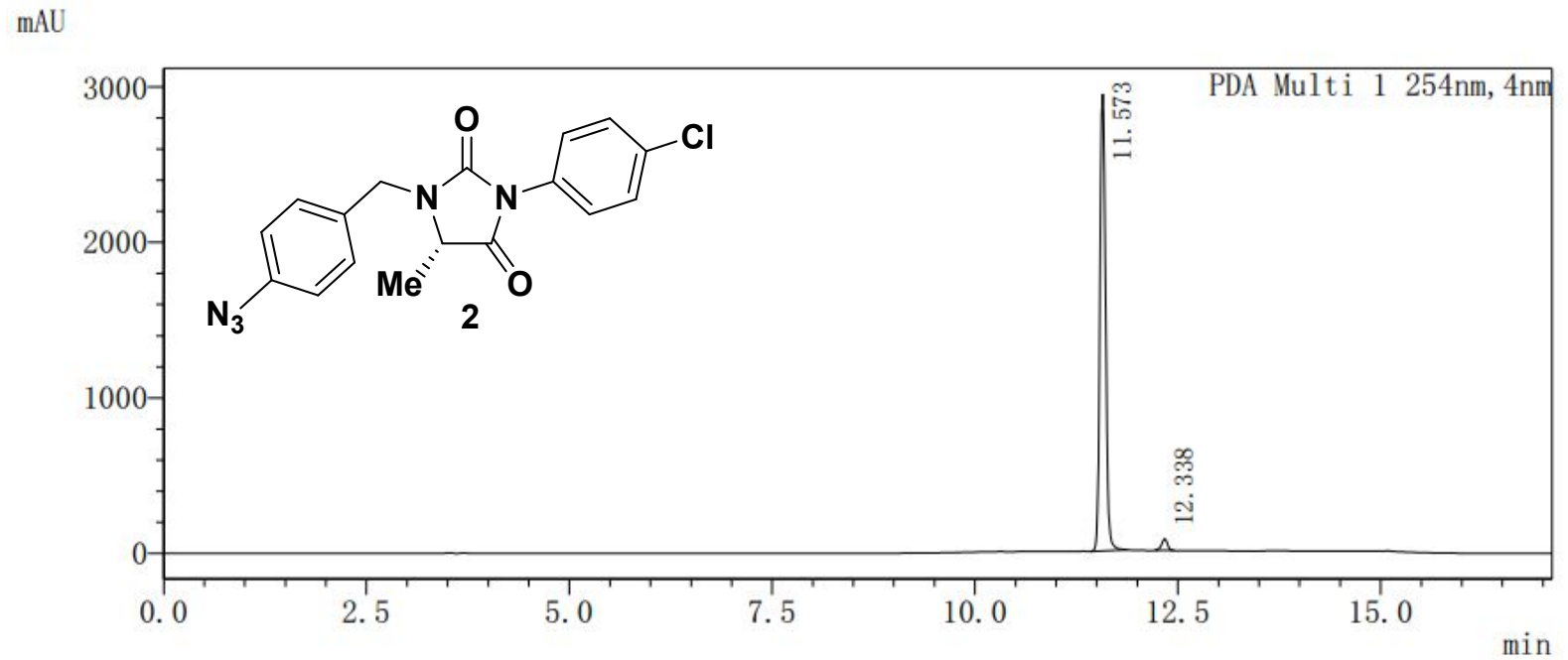

PDA Ch1 254nm

\begin{tabular}{|c|c|c|c|c|c|}
\hline Peak\# & Ret. Time (min) & Height(mAU) & Height $\%$ & Area(mAU*s) & Area\% \\
\hline 1 & 11.573 & 2938069 & 97.549 & 14381767 & 97.537 \\
\hline 2 & 12.338 & 73813 & 2.451 & 363120 & 2.463 \\
\hline 总计 & & 3011882 & 100.000 & 14744887 & 100.000 \\
\hline
\end{tabular}




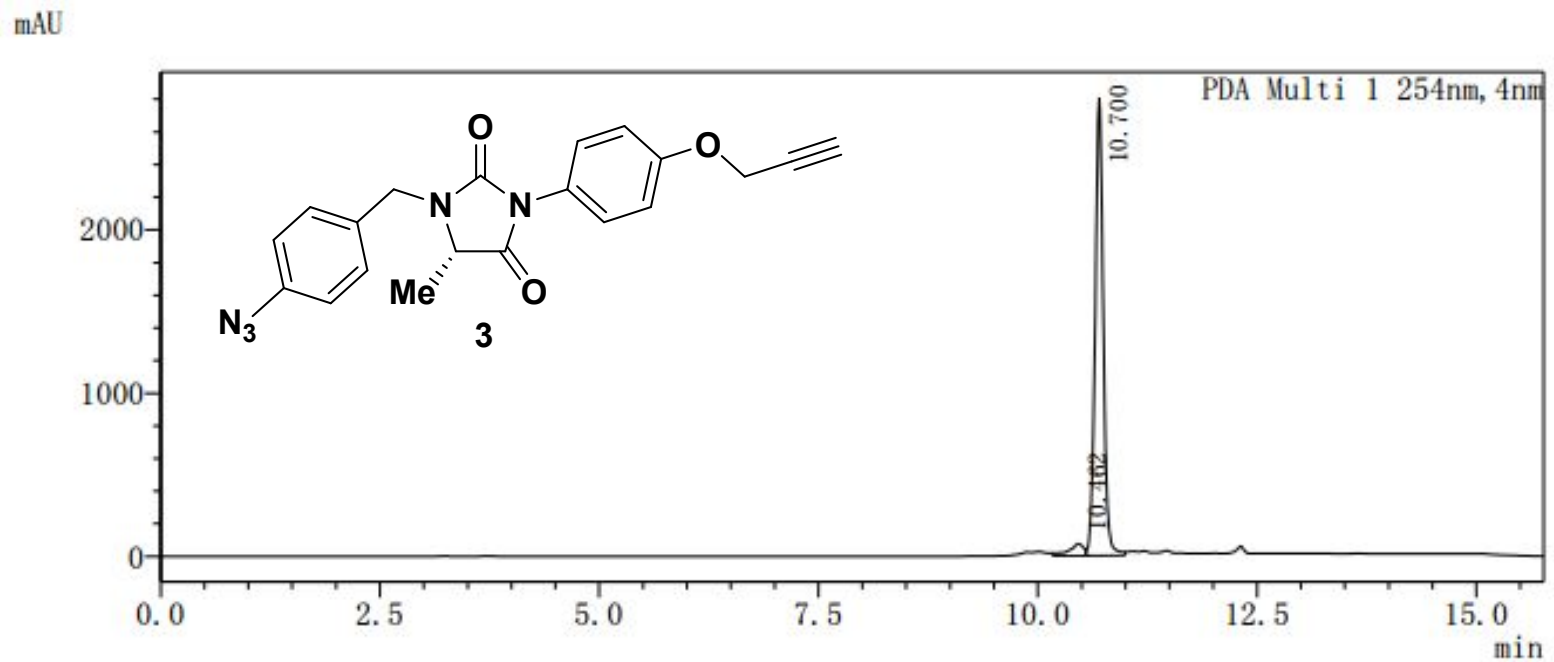

PDA Ch1 254nm

\begin{tabular}{|c|c|c|c|c|c|}
\hline Peak\# & Ret. Time (min) & Height(mAU) & Height $\%$ & Area(mAU*s) & Area $\%$ \\
\hline 1 & 10.462 & 72922 & 2.534 & 872271 & 4.590 \\
\hline 2 & 10.700 & 2804875 & 97.466 & 18131772 & 95.410 \\
\hline 总计 & & 2877797 & 100.000 & 19004043 & 100.000 \\
\hline
\end{tabular}

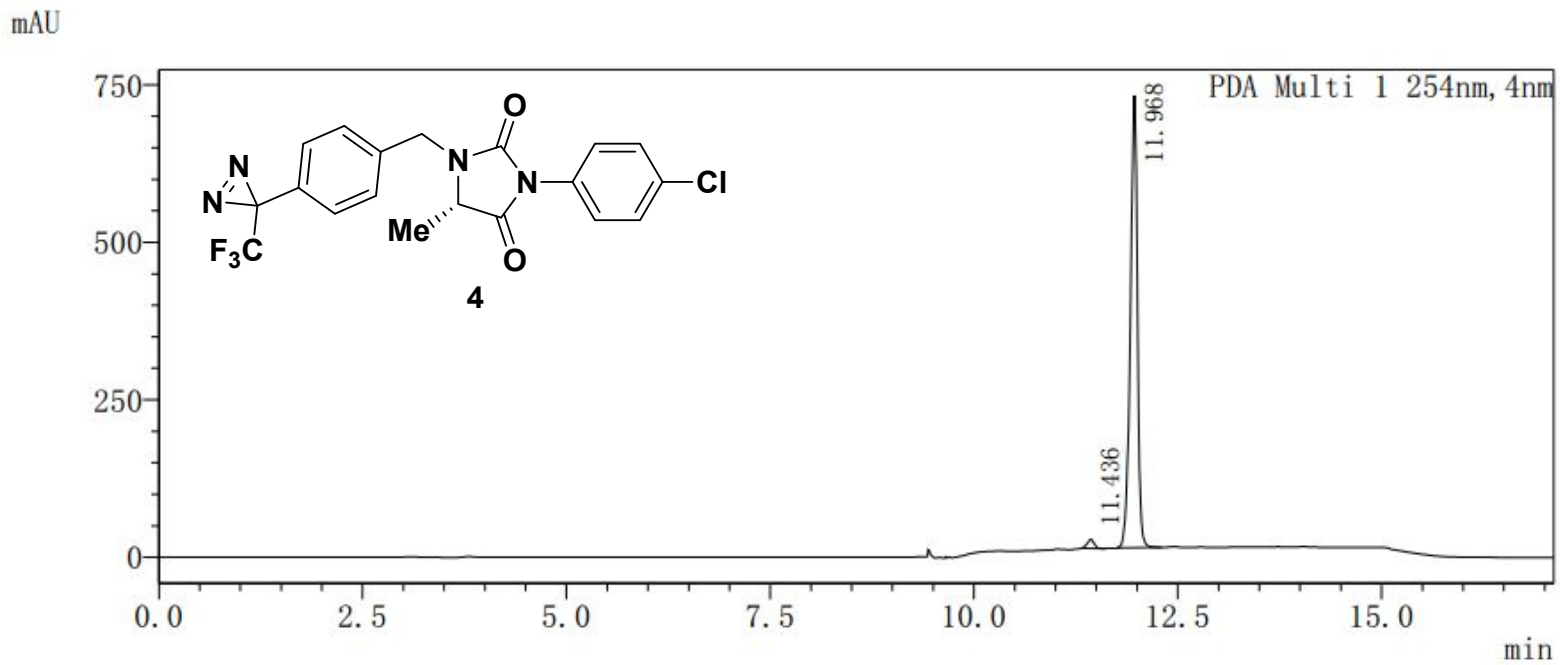

PDA Ch1 254nm

\begin{tabular}{|c|c|c|c|c|c|}
\hline Peak\# & Ret. Time (min) & Height(mAU) & Height $\%$ & Area(mAU*s) & Area $\%$ \\
\hline 1 & 11.436 & 14334 & 1.958 & 81032 & 1.842 \\
\hline 2 & 11.968 & 717828 & 98.042 & 4319056 & 98.158 \\
\hline 总计 & & 732161 & 100.000 & 4400087 & 100.000 \\
\hline
\end{tabular}




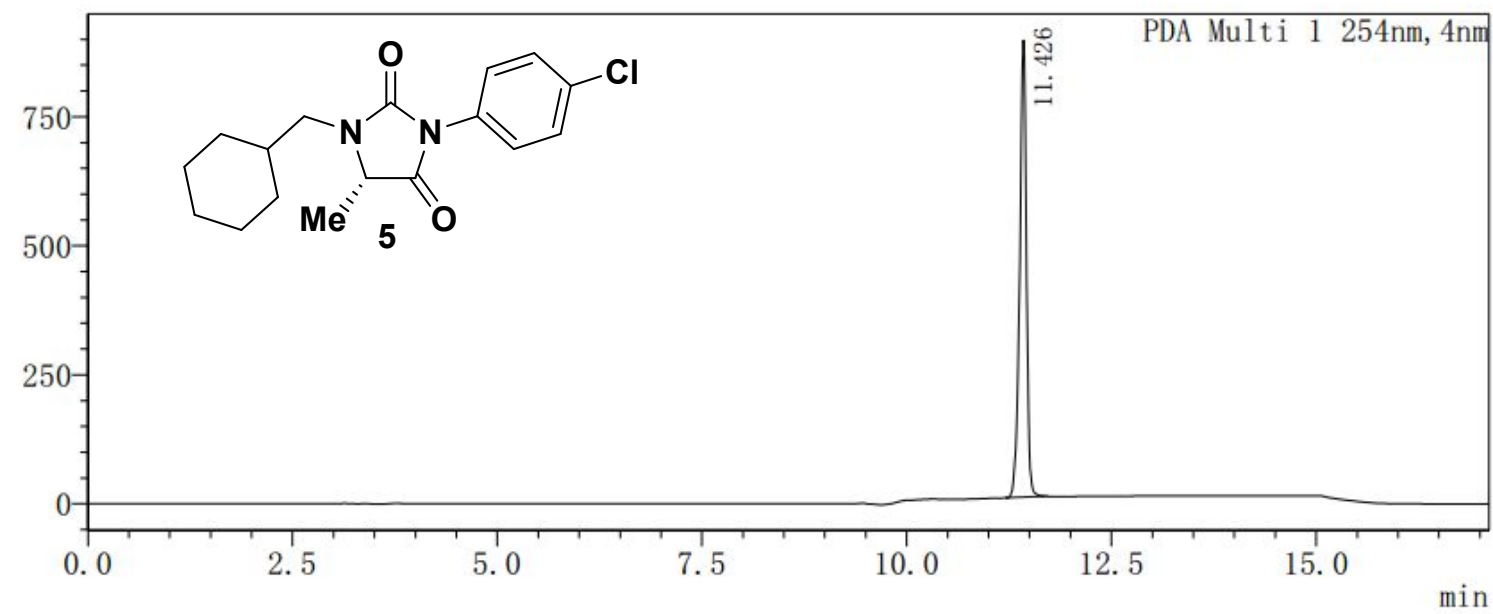

PDA Ch1 254nm

\begin{tabular}{|c|c|c|c|c|c|}
\hline Peak\# & Ret. Time (min) & Height(mAU) & Height $\%$ & Area(mAU*s) & Area $\%$ \\
\hline 1 & 11.426 & 886041 & 100.000 & 5085639 & 100.000 \\
\hline 总计 & & 886041 & 100.000 & 5085639 & 100.000 \\
\hline
\end{tabular}

$\mathrm{mAU}$

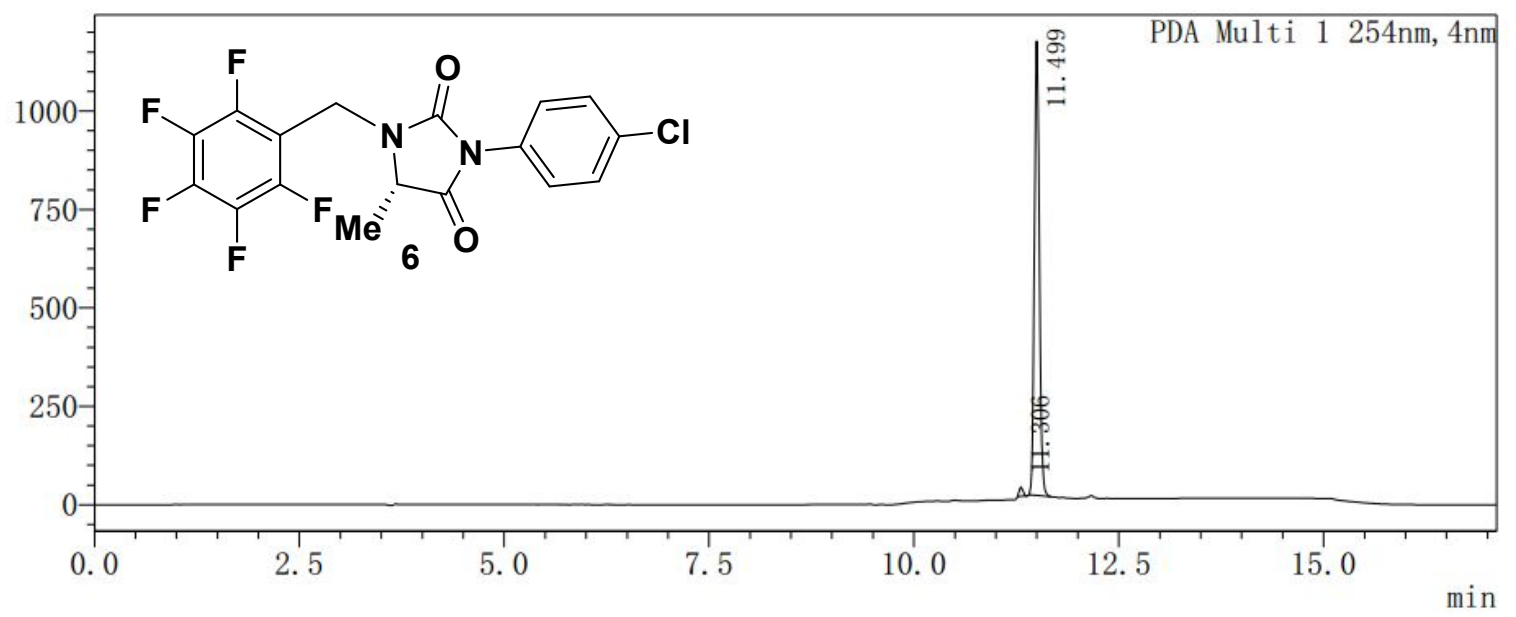

PDA Ch1 254nm

\begin{tabular}{|c|c|c|c|c|c|}
\hline Peak\# & Ret. Time (min) & Height(mAU) & Height $\%$ & Area(mAU*s) & Area\% \\
\hline 1 & 11.306 & 22947 & 1.949 & 72089 & 1.467 \\
\hline 2 & 11.499 & 1154478 & 98.051 & 4841368 & 98.533 \\
\hline 总计 & & 1177425 & 100.000 & 4913457 & 100.000 \\
\hline
\end{tabular}



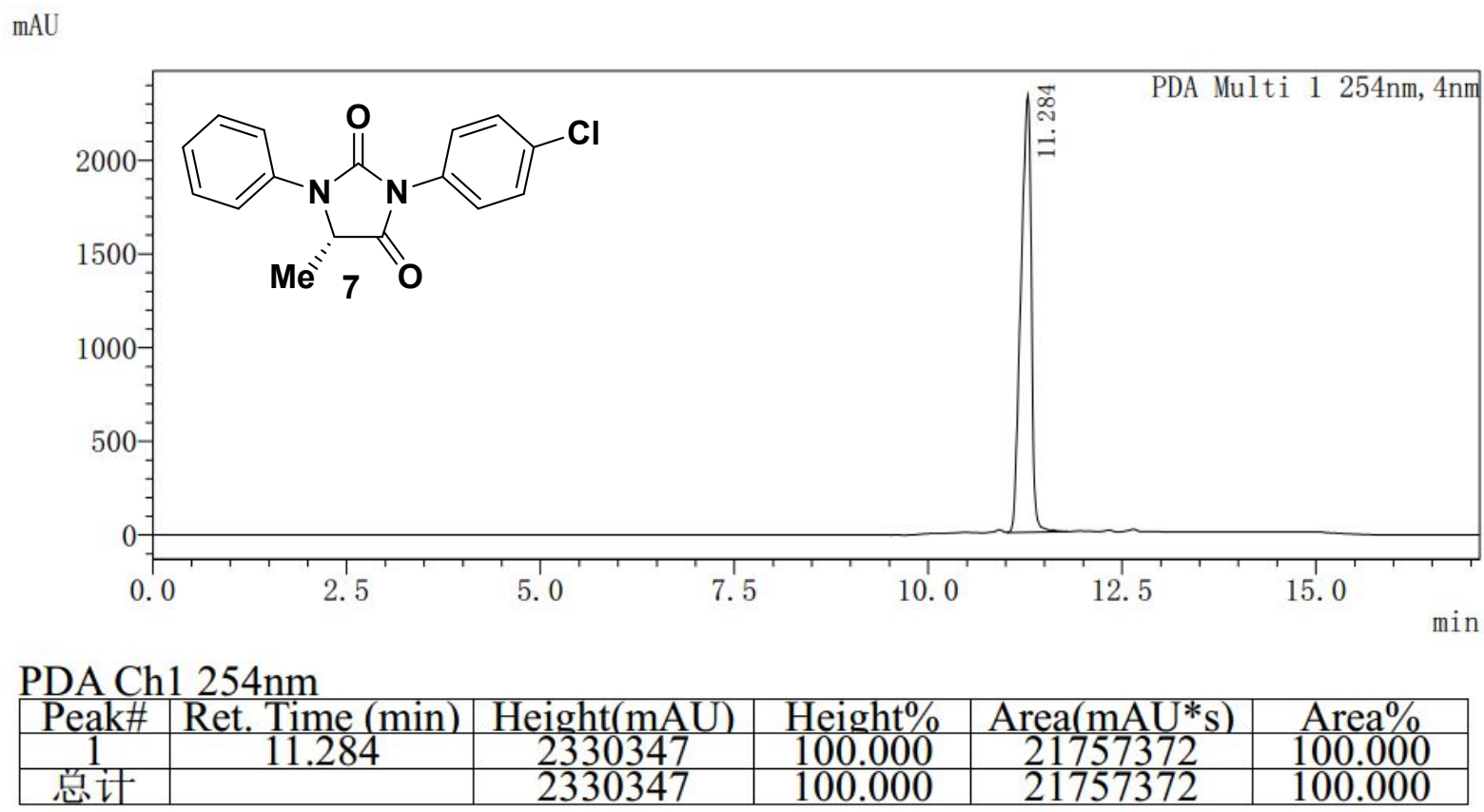
mAU

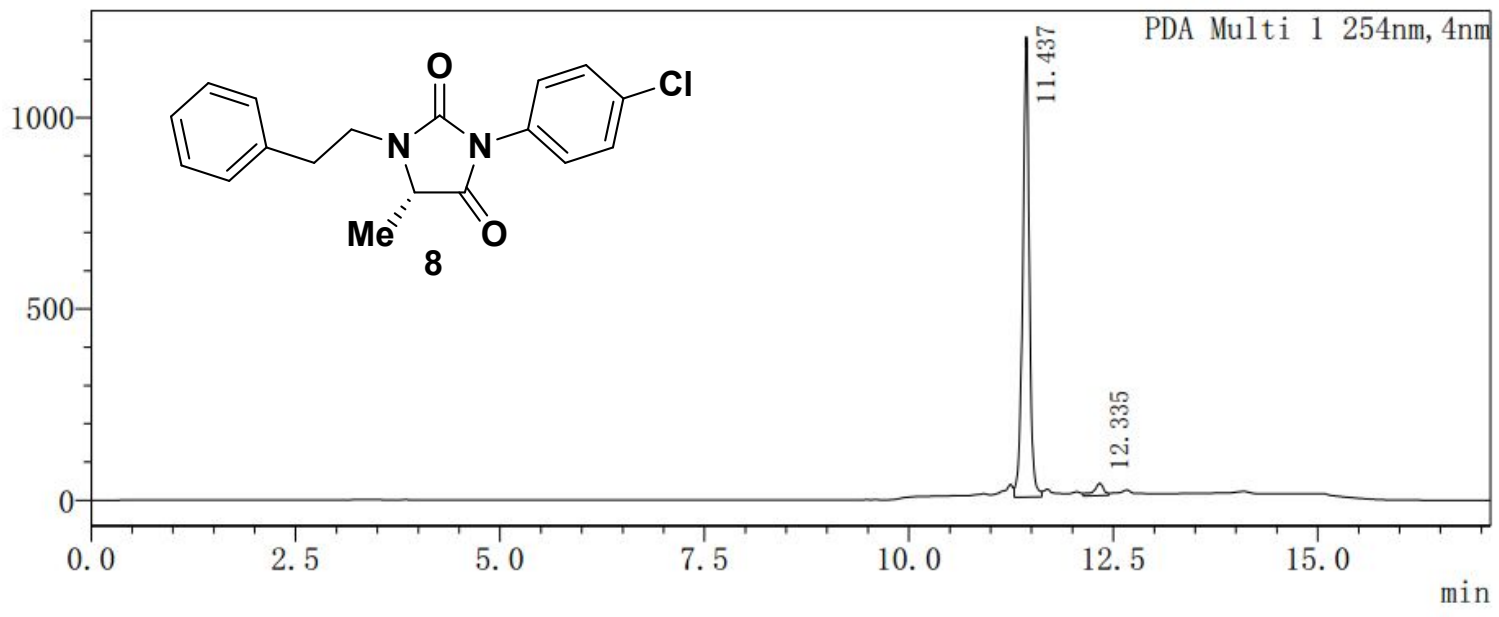

PDA Ch1 254nm

\begin{tabular}{|c|c|c|c|c|c|}
\hline Peak\# & Ret. Time (min) & Height(mAU) & Height $\%$ & Area(mAU*s) & Area\% \\
\hline 1 & 11.437 & 1203263 & 97.402 & 6733194 & 96.121 \\
\hline 2 & 12.335 & 32094 & 2.598 & 271729 & 3.879 \\
\hline 总计 & & 1235357 & 100.000 & 7004923 & 100.000 \\
\hline
\end{tabular}




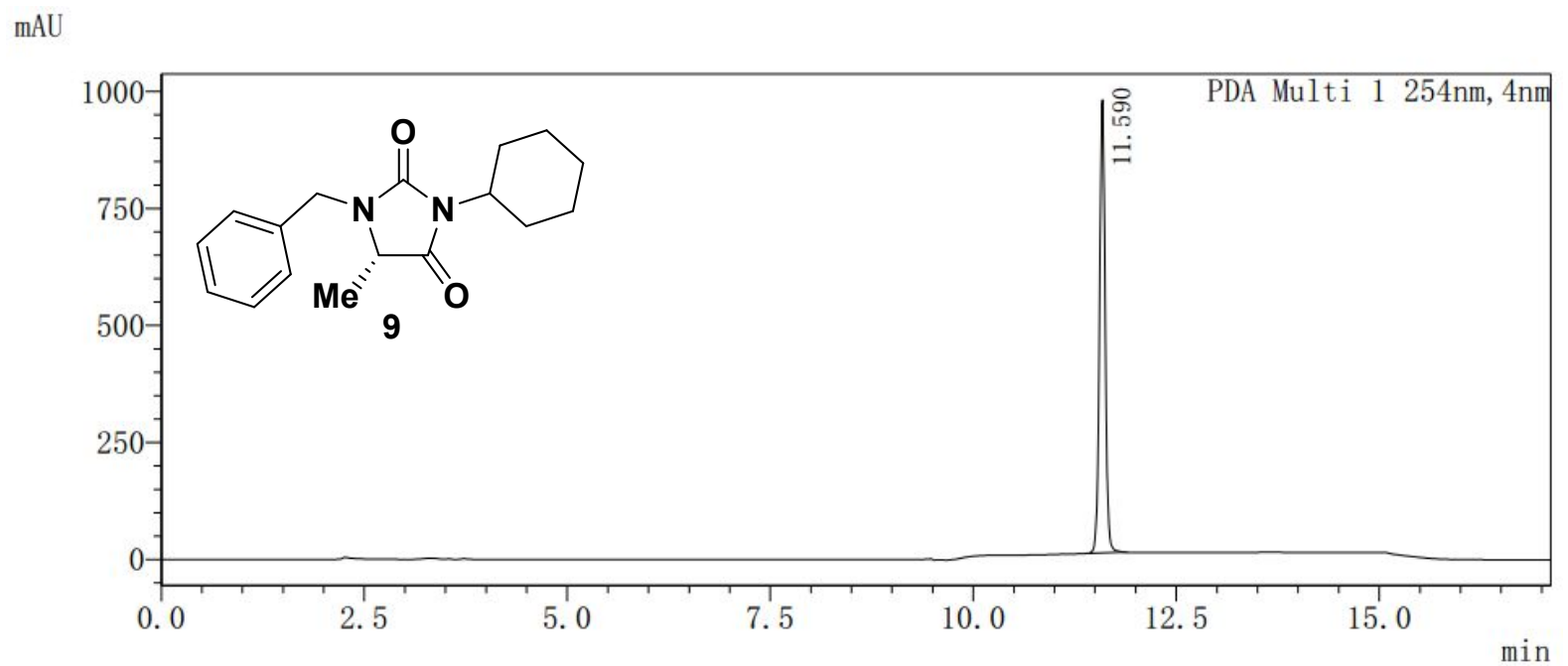

PDA Ch1 254nm

\begin{tabular}{|c|c|c|c|c|c|}
\hline Peak\# & Ret. Time (min) & Height(mAU) & Height $\%$ & Area(mAU*s) & Area $\%$ \\
\hline 1 & 11.590 & 967987 & 100.000 & 4656821 & 100.000 \\
\hline 总计 & & 967987 & 100.000 & 4656821 & 100.000 \\
\hline
\end{tabular}

$\mathrm{mAU}$

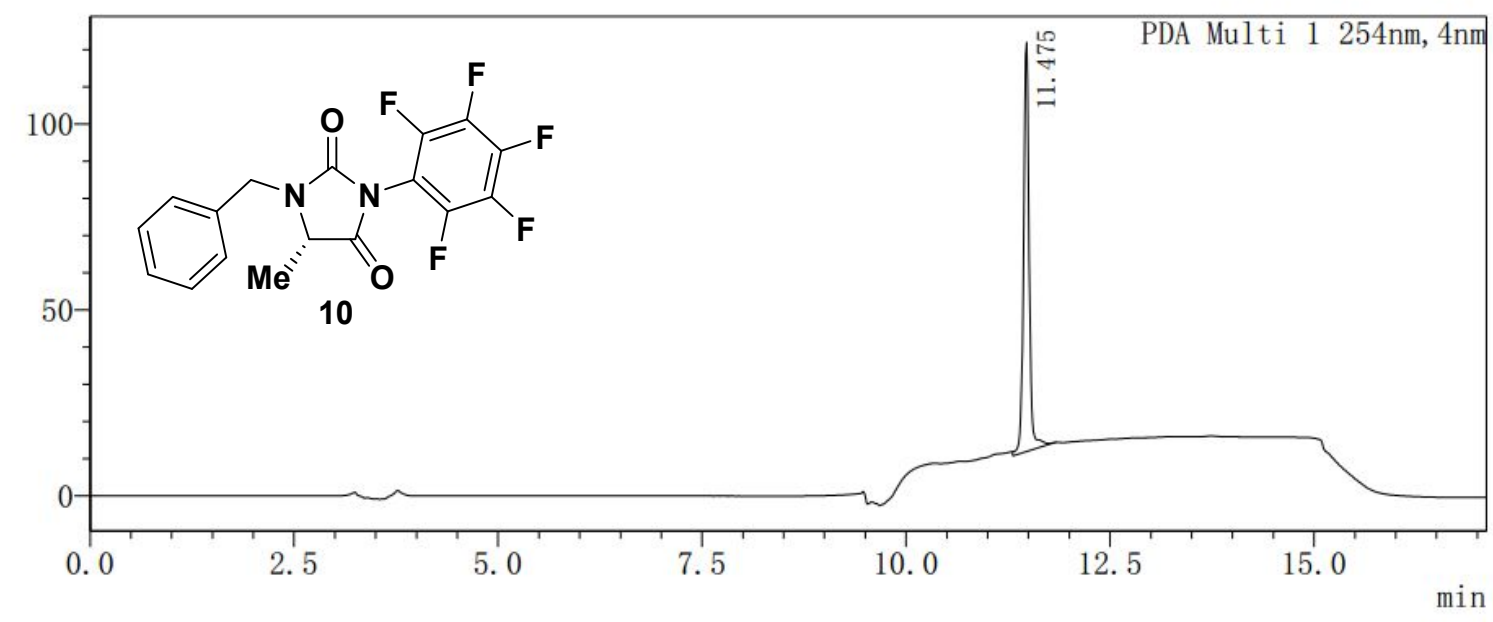

PDA Ch1 254nm

\begin{tabular}{|c|c|c|c|c|c|}
\hline Peak\# & Ret. Time (min) & Height(mAU) & Height $\%$ & Area(mAU*s) & Area $\%$ \\
\hline 1 & 11.475 & 109978 & 100.000 & 522483 & 100.000 \\
\hline 总计 & & 109978 & 100.000 & 522483 & 100.000 \\
\hline
\end{tabular}


mAU

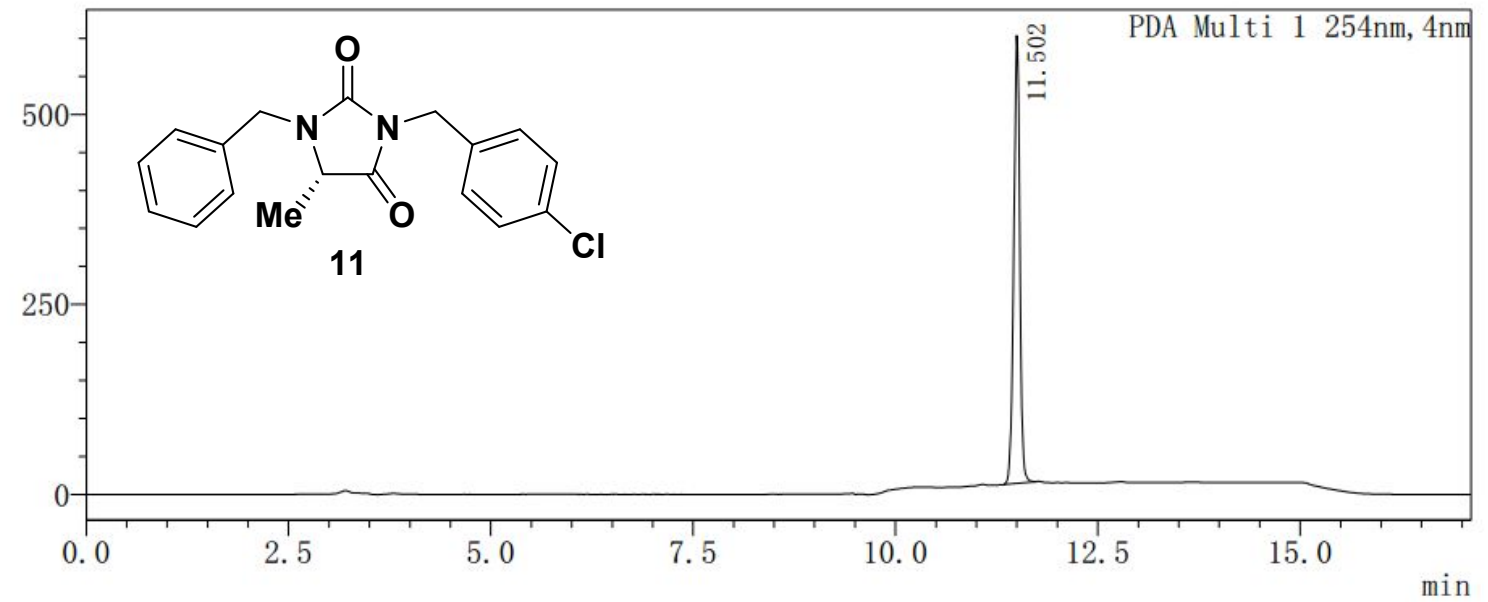

PDA Ch1 254nm

\begin{tabular}{|c|c|c|c|c|c|}
\hline Peak\# & Ret. Time (min) & Height(mAU) & Height $\%$ & Area(mAU*s) & Area $\%$ \\
\hline 1 & 11.502 & 589387 & 100.000 & 3050952 & 100.000 \\
\hline 总计 & & 589387 & 100.000 & 3050952 & 100.000 \\
\hline
\end{tabular}

mAU

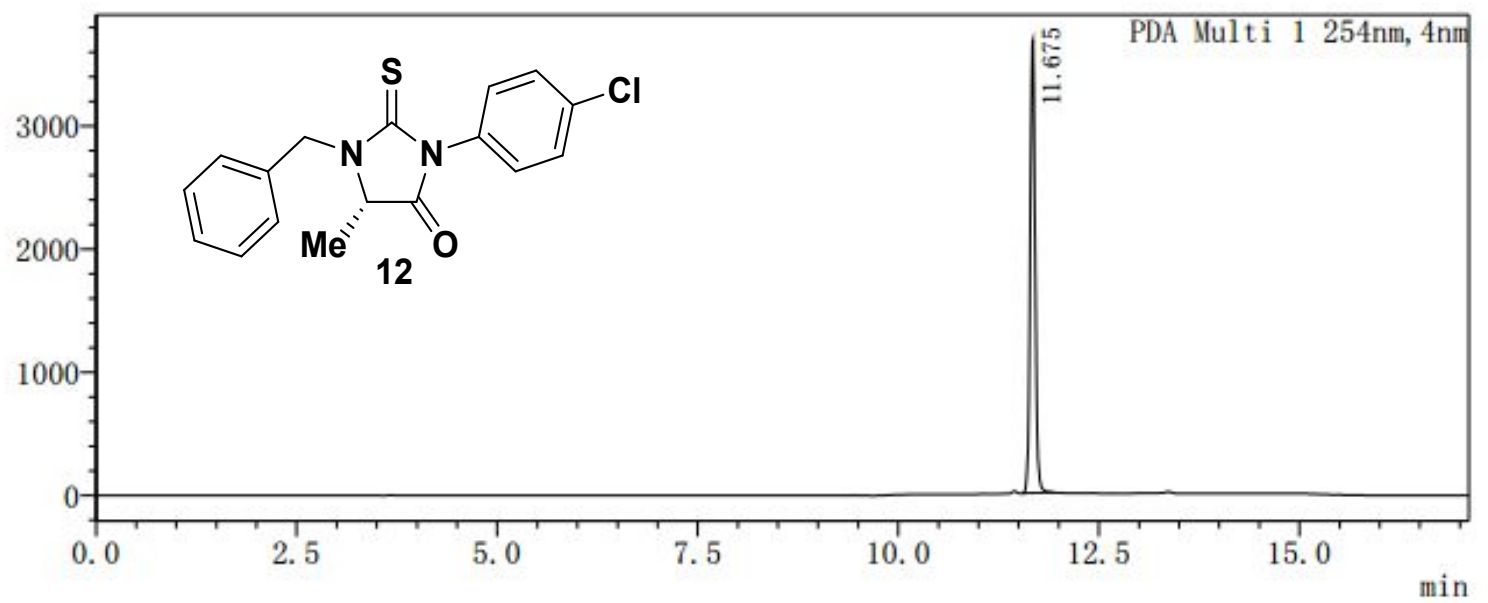

PDA Ch1 254nm

\begin{tabular}{|c|c|c|c|c|c|}
\hline Peak\# & Ret. Time (min) & Height(mAU) & Height\% & Area(mAU*s) & Area\% \\
\hline 1 & 11.675 & 3677534 & 100.000 & 16072273 & 100.000 \\
\hline 总计 & & 3677534 & 100.000 & 16072273 & 100.000 \\
\hline
\end{tabular}


$\mathrm{mAU}$

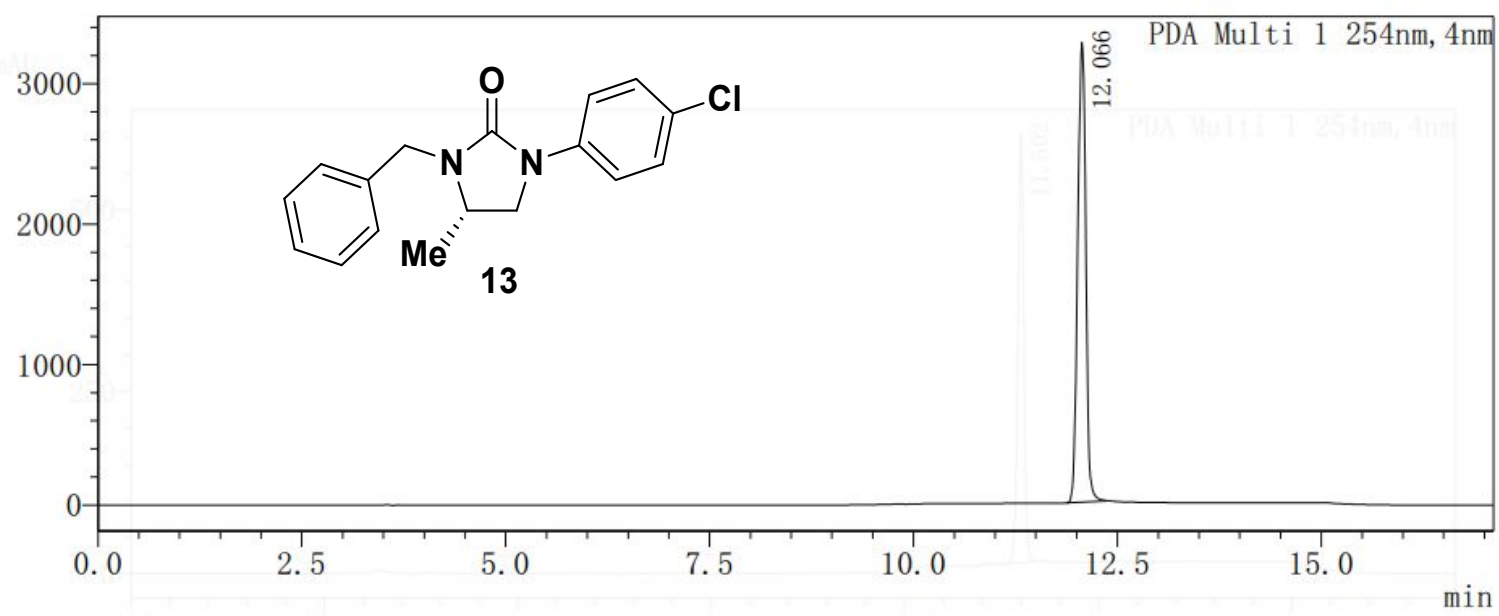

PDA Ch1 254nm

\begin{tabular}{|c|c|c|c|c|c|}
\hline Peak\# & Ret. Time $(\mathrm{min})$ & Height(mAU) & Height $\%$ & Area(mAU*s) & Area\% \\
\hline 1 & 12.066 & 3273420 & 100.000 & 22612991 & 100.000 \\
\hline 总计 & & 3273420 & 100.000 & 22612991 & 100.000 \\
\hline
\end{tabular}




\section{References}

1. Tao, H.; Jin, Q.; Koo, D. I.; Liao, X.; Englund, N. P.; Wang, Y.; Ramamurthy, A.; Schultz, P. G.; Dorsch, M.; Kelleher, J.; Wu, X., Small molecule antagonists in distinct binding modes inhibit drug-resistant mutant of smoothened. Chem. Biol. 2011, 18, 432-437

2. Chen, J. K.; Taipale, J.; Young, K. E.; Maiti, T.; Beachy, P. A., Small molecule modulation of Smoothened activity. Proc. Natl. Acad. Sci. 2002, 99, 14071-14076.

3. Wang, C.; Wu, H.; Evron, T.; Vardy, E.; Han, G. W.; Huang, X. P.; Hufeisen, S. J.; Mangano, T. J.; Urban, D. J.; Katritch, V.; Cherezov, V.; Caron, M. G.; Roth, B. L.; Stevens, R. C., Structural basis for Smoothened receptor modulation and chemoresistance to anticancer drugs. Nat. Commun. 2014, 5, 4355-4365.

4. Sastry, G. M.; Adzhigirey, M.; Day, T.; Annabhimoju, R.; Sherman, W., Protein and ligand preparation: parameters, protocols, and influence on virtual screening enrichments. J. Comput. Aided. Mol. Des. 2013, 27, 221-234.

5. Schrödinger, L., Small-Molecule Drug Discovery Suite 2015-4. New York, NY 2018.

6. Friesner, R. A.; Banks, J. L.; Murphy, R. B.; Halgren, T. A.; Klicic, J. J.; Mainz, D. T.; Repasky, M. P.; Knoll, E. H.; Shelley, M.; Perry, J. K.; Shaw, D. E.; Francis, P.; Shenkin, P. S., Glide: A new approach for rapid, accurate docking and scoring. 1. Method and assessment of docking accuracy. J.Med. Chem. 2004, 47, 1739-1749.

7. Sherman, W.; Beard, H. S.; Farid, R., Use of an induced fit receptor structure in virtual screening. Chem. Biol. Drug. Des. 2006, 67, 83-84.

8. Huang, N.; Kalyanaraman, C.; Bernacki, K.; Jacobson, M. P., Molecular mechanics methods for predicting protein-ligand binding. Phys. Chem. Chem. Phys. 2006, 8, 5166-5177. 9. Abraham, M. J.; Murtola, T.; Schulz, R.; Páll, S.; Smith, J. C.; Hess, B.; Lindahl, E., GROMACS: High performance molecular simulations through multi-level parallelism from laptops to supercomputers. Softwarex 2015, s 1-2 (C), 19-25.

10. Lindorff-Larsen, K.; Piana, S.; Palmo, K.; Maragakis, P.; Klepeis, J. L.; Dror, R. O.; Shaw, D. E., Improved side-chain torsion potentials for the Amber ff99SB protein force field. Proteins 2010, 78 (8), 1950-1958.

11. Case, D. A.; Cheatham, T. E.; Darden, T.; Gohlke, H.; Luo, R.; Merz, K. M.; Onufriev, A.; Simmerling, C.; Wang, B.; Woods, R. J., The Amber biomolecular simulation programs. $J$ Comput. Chem. 2005, 26, 1668-1688.

12. Wang, J. M.; Wolf, R. M.; Caldwell, J. W.; Kollman, P. A.; Case, D. A., Development and testing of a general amber force field. J Comput. Chem. 2004, 25, 1157-1174.

13. Sousa da Silva, A. W.; Vranken, W. F., ACPYPE - AnteChamber PYthon Parser interfacE. BMC Res Notes 2012, 5, 367.

14. Jo, S.; Kim, T.; Iyer, V. G.; Im, W., CHARMM-GUI: a web-based graphical user interface for CHARMM. Journal of computational chemistry 2008, 29, 1859-1865.

15. Jambeck, J. P. M.; Lyubartsev, A. P., An Extension and Further Validation of an AllAtomistic Force Field for Biological Membranes. J Chem. Theory. Comput. 2012, 8, 29382948.

16. Hess, B.; Bekker, H.; Berendsen, H. J. C.; Fraaije, J. G. E. M., LINCS: A linear constraint solver for molecular simulations. J Comput. Chem. 1997, 18, 1463-1472.

17. Wojcikowski, M.; Zielenkiewicz, P.; Siedlecki, P., Open Drug Discovery Toolkit (ODDT): a new open-source player in the drug discovery field. J Cheminform. 2015, 7, 26-31. 
18. Stromgaard, K.; Saito, D. R.; Shindou, H.; Ishii, S.; Shimizu, T.; Nakanishi, K., Ginkgolide derivatives for photolabeling studies: preparation and pharmacological evaluation. $J$ Med. Chem. 2002, 45, 4038-4046. 